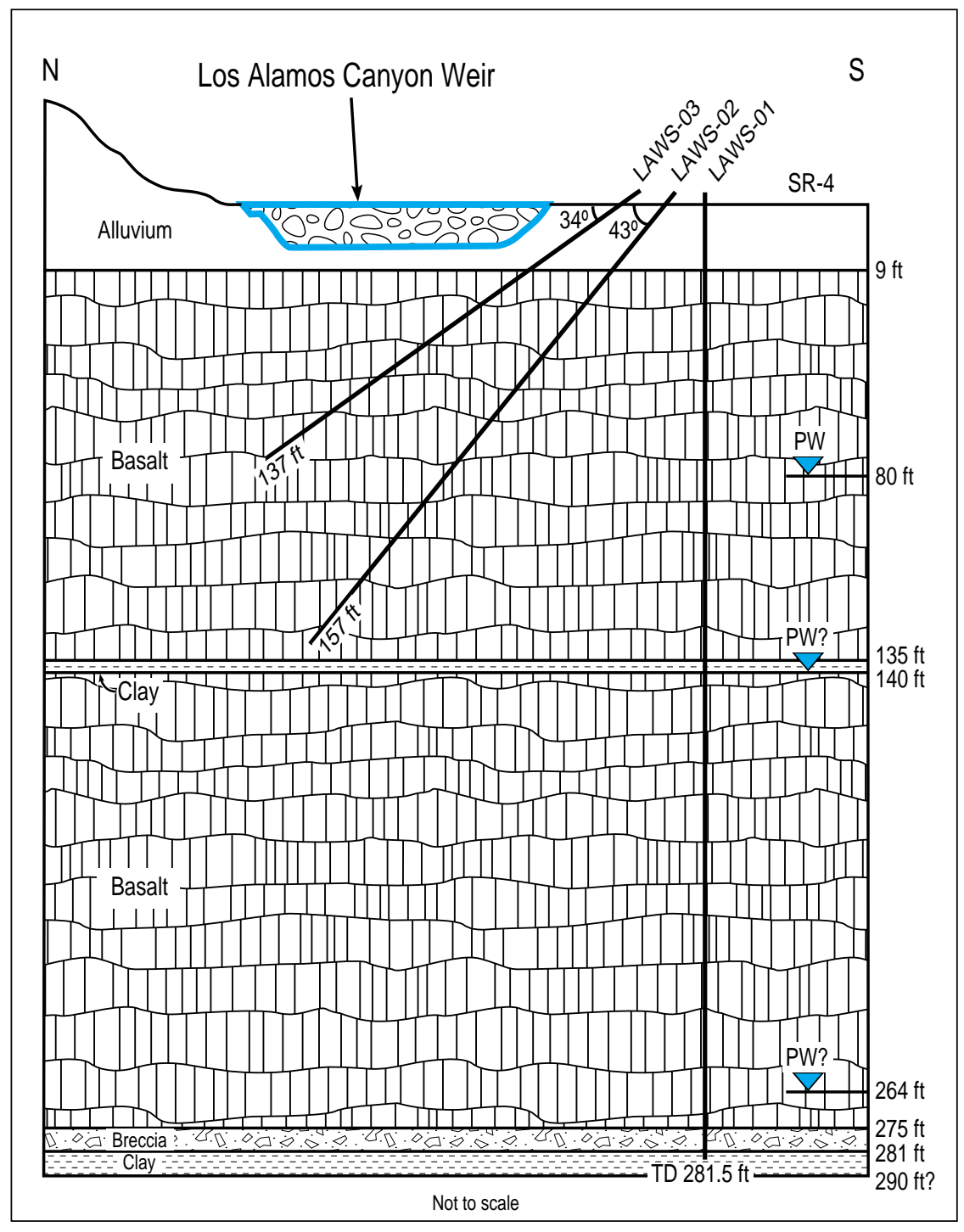




\section{Produced for the Cerro Grande Rehabilitation Project}

Los Alamos National Laboratory, an affirmative action/equal opportunity employer, is operated by the University of California for the United States Department of Energy under contract W-7405-ENG-36.

This report was prepared as an account of work sponsored by an agency of the United States Government. Neither the Regents of the University of California, the United States Government nor any agency thereof, nor any of their employees make any warranty, express or implied, or assume any legal liability or responsibility for the accuracy, completeness, or usefulness of any information, apparatus, product, or process disclosed, or represent that its use would not infringe privately owned rights. Reference herein to any specific commercial product, process, or service by trade name, trademark, manufacturer, or otherwise does not necessarily constitute or imply its endorsement, recommendation, or favoring by the Regents of the University of California, the United States Government, or any agency thereof.

Los Alamos National Laboratory strongly supports academic freedom and a researcher's right to publish; as an institution, however, the Laboratory does not endorse the viewpoint of a publication or guarantee its technical correctness. By acceptance of this article, the publisher recognizes that the U.S. Government retains a nonexclusive, royalty-free license to publish or reproduce the published form of this contribution, or to allow others to do so, for U.S. Government purposes. Los Alamos National Laboratory requests that the publisher identify this article as work performed under the auspices of the U.S. Department of Energy. 



\section{TABLE OF CONTENTS}

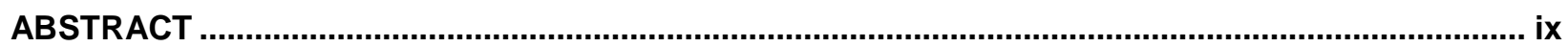

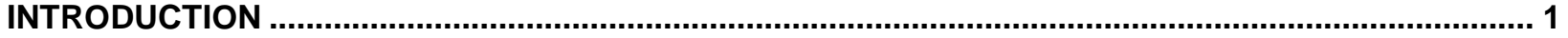

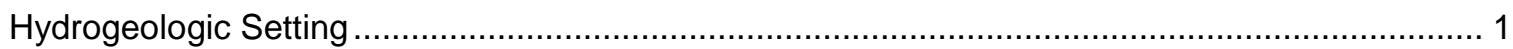

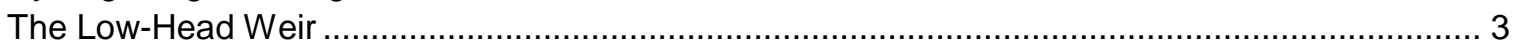

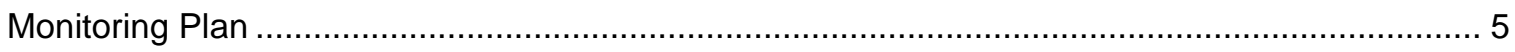

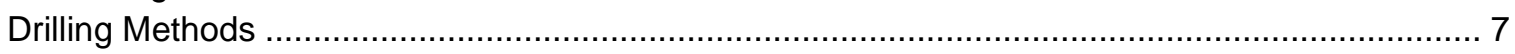

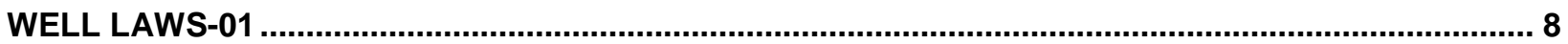

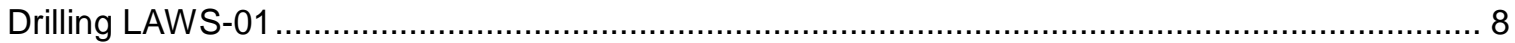

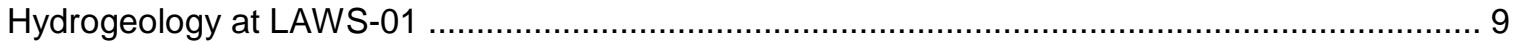

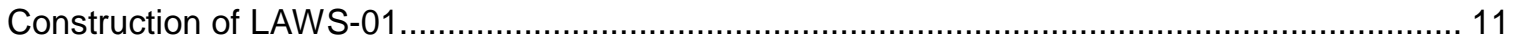

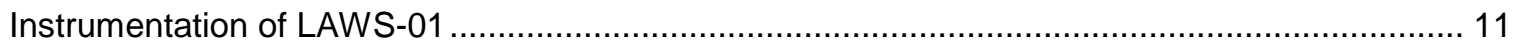

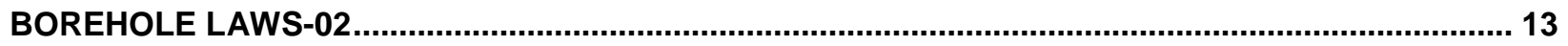

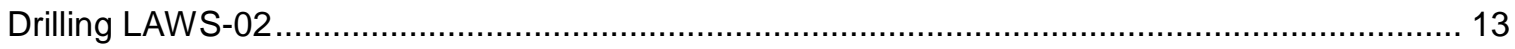

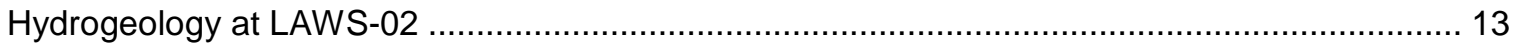

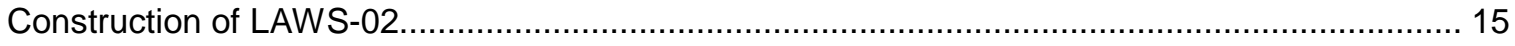

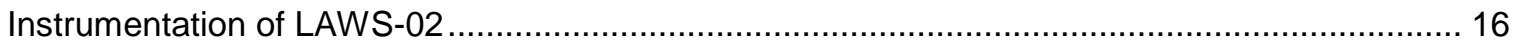

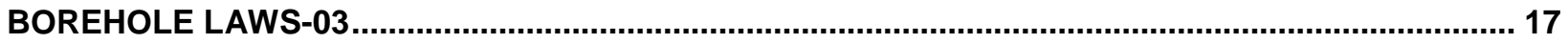

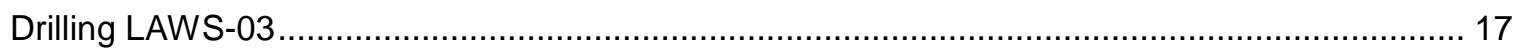

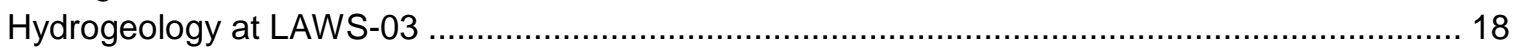

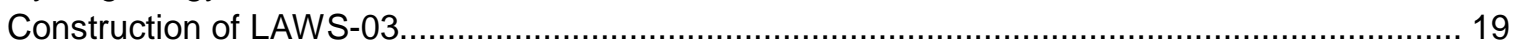

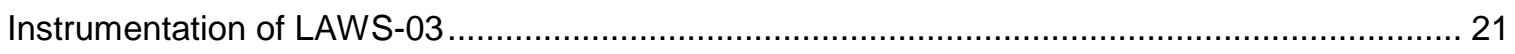

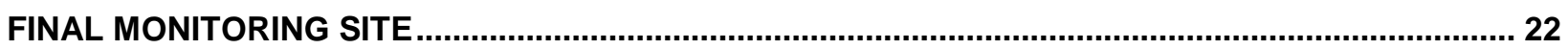

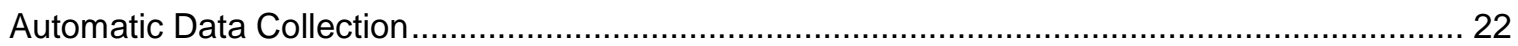

Power Supply

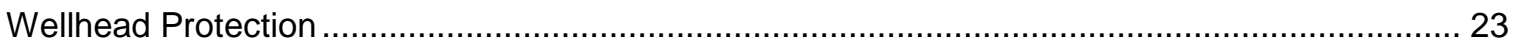

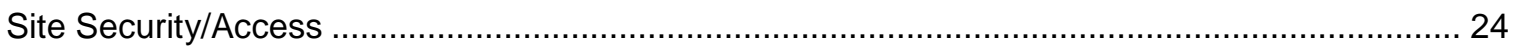

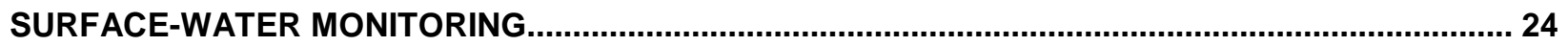

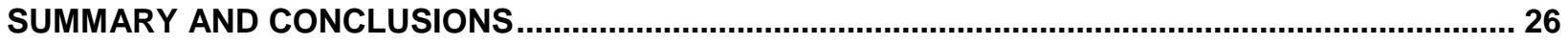

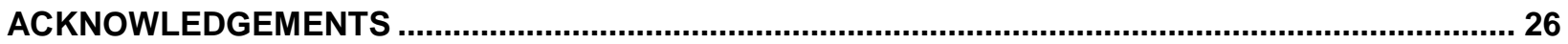

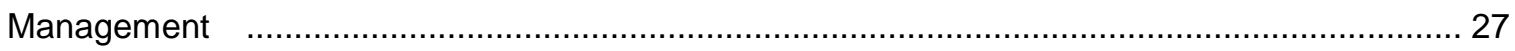

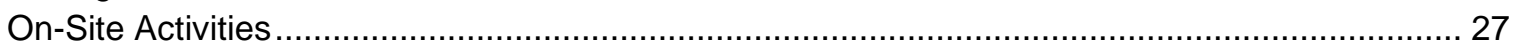

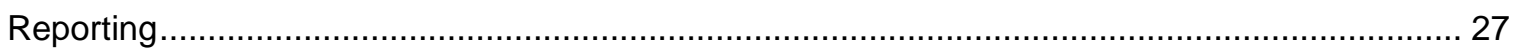

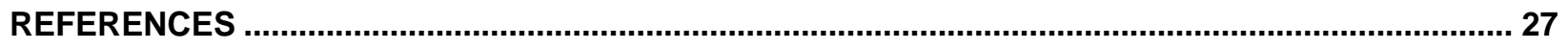

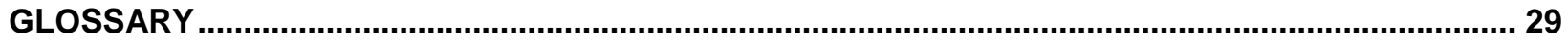




\section{Appendices}

Appendix A Detailed Field Logs for the Well and Angled Boreholes

Appendix B Water FLUTe ${ }^{\mathrm{TM}}$ System installed in LAWS-01

Appendix C Construction of Angled Boreholes

Appendix D Wellhead Completion for Well and Boreholes

\section{List of Figures}

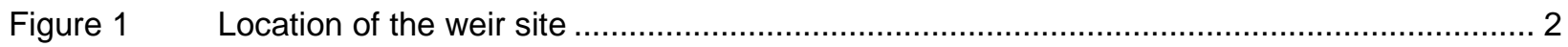

Figure 2 Hydrogeology and well construction at characterization well R-9i................................... 3

Figure $3 \quad$ The Los Alamos Canyon low-head weir with ponded runoff ............................................. 4

Figure $4 \quad$ Detailed topographic map of the area behind the weir ................................................... 4

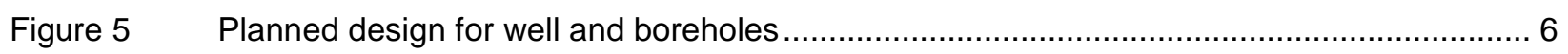

Figure $6 \quad$ Actual configuration of well and boreholes .............................................................. 7

Figure $7 \quad$ CME-750 auger rig setting surface casing at LAWS-01 ............................................... 8

Figure $8 \quad$ Schramm rotary rig drilling LAWS-02 by casing-advance method ................................... 9

Figure 9 Geology, construction, and perched water levels at LAWS-01 ....................................... 10

Figure 10 Schematic diagram showing deployment of a Water FLUTe ${ }^{\mathrm{TM}}$ system; water inside liner

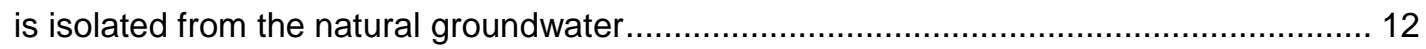

Figure 11 Installing the Water FLUTe ${ }^{\mathrm{TM}}$ system at LAWS-01; hose at left will deliver water to the inside of the liner for everting it into the well ................................................................. 12

Figure 12 Geology along angled borehole LAWS-02 .............................................................. 14

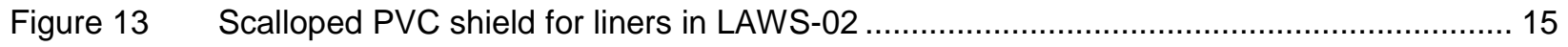

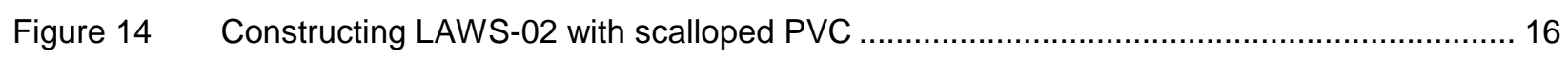

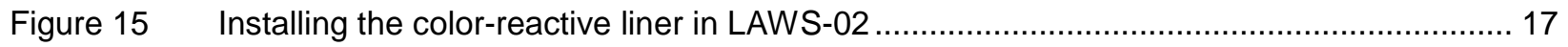

Figure 16 Geology along angled borehole LAWS-03 ............................................................. 18

Figure 17 Perforated PVC shield (covered with wicking fabric) for liners in LAWS-03..................... 20

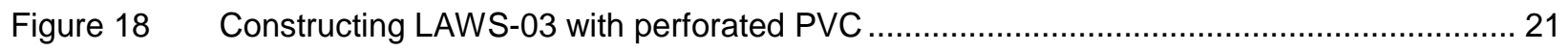

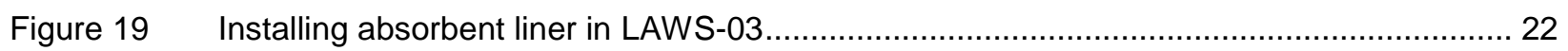

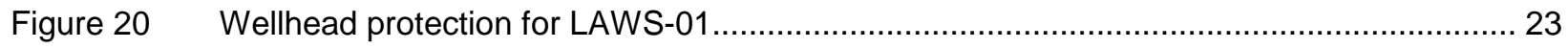

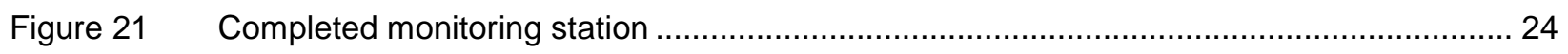

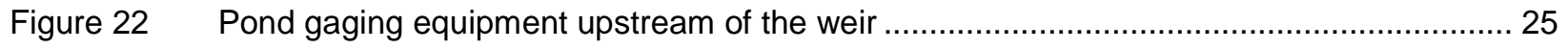

Figure 23 Stream gaging and sampling station downstream of the weir ........................................ 25

(Photographs were taken by the authors or field team unless otherwise noted.)

\section{List of Tables}

Table 1 Geodetic Data for the Well and Boreholes at the Weir Monitoring Site.............................. 1

Table 2 Summary of Straddle-Packer/Injection Testing at Characterization Well R-9i ..................... 3

Table 3 Depth of Sampling and Transducer Points in LAWS-01 ............................................ 13 


\section{List of Abbreviations and Acronyms}

bgs below ground surface

cfs cubic feet per second

CGRP Cerro Grande Rehabilitation Project

DDI Dynatec Drilling, Inc.

dpm disintegrations per minute

EES Earth and Environmental Science (Division)

ER Environmental Restoration (Project)

ESH Environmental Safety and Health (Division)

FLUTe Flexible Liner Underground Technology, Inc.

$\mathrm{ft} / \mathrm{d} \quad$ feet per day

gpm gallons per minute

I.D. inside diameter

LANL Los Alamos National Laboratory

LATA Los Alamo Technical Associates

LAWS Los Alamos weir site (well-number prefix)

$\mu \mathrm{S} / \mathrm{cm}$ microSiemens per centimeter (unit of measure for specific conductance)

NA not applicable or not available

NTU nephelometric turbidity units

O.C. on center (refers to space between centers of holes in perforated PVC)

O.D. outside diameter

PVC polyvinyl chloride

Qal Quaternary alluvium

RRES Risk Reduction and Environmental Stewardship (Division)

SAA same as above

SBDC Stewart Brothers Drilling Co.

SEA Science and Engineering Associates, Inc.

TD total depth

UDR underground drilling rig 



\title{
Installation of the Monitoring Site at the Los Alamos Canyon Low-Head Weir
}

by

\author{
William J. Stone and Dennis L. Newell
}

\begin{abstract}
The Cerro Grande fire of 2000 had an enormously adverse impact on and around Los Alamos National Laboratory (LANL). Immediately there were concerns about the potential for enhanced runoff/offsite transport of contaminant-laden sediments because of watershed damage. In response to this concern, the U.S. Army Corps of Engineers installed a low-head weir in Los Alamos Canyon near the White Rock "Y." However, the occurrence of fractured basalt at the surface and ponding of runoff behind the weir enhance the possibility of downward migration of contaminants. Therefore, three boreholes were drilled on the south bank of the channel by LANL to provide a means of monitoring the impact of the Cerro Grande fire and of the weir on water quality beneath the canyon. The boreholes and associated instrumentation are referred to as the Los Alamos Weir Site (LAWS).
\end{abstract}

The three boreholes include a vertical hole and two angled holes (one at approximately $45^{\circ}$ and one at approximately $30^{\circ}$ ). Since the basalt is highly fractured, the holes would not stay open. Plans called for inserting flexible liners into all holes. However, using liners in such unstable ground was problematic and, in the angled holes, required deployment through scalloped or perforated polyvinyl chloride (PVC) shield.

The vertical hole (LAWS-01), drilled to a total depth of $281.5 \mathrm{ft}$ below ground surface (bgs), was completed as a 278 -ft deep monitoring well with four screens: one targeting shallow perched water encountered at $80 \mathrm{ft}$, two in what may correspond to the upper perched zone at regional groundwater characterization well R-9i (1/4 mi. to the west), and one in what may correspond to the lower perched zone at R-9i. A Water FLUTe ${ }^{\mathrm{TM}}$ system deployed in the well isolates the screened intervals; associated transducers and sampling ports permit monitoring head and water quality in the screened intervals.

The second hole (LAWS-02), drilled at an angle of $43^{\circ}$ from horizontal, is $156 \mathrm{ft}$ long and bottoms at a depth of $106 \mathrm{ft}$ bgs. The shallow perched water seen at LAWS-01 (at $80 \mathrm{ft}$ ) was not encountered. A scalloped PVC shield was installed to keep the hole open while permitting flexible liners to contact the borehole wall. It was initially instrumented with a color-reactive liner to locate water-producing fractures. That was later replaced by an absorbent liner to collect water from the vadose zone.

The third hole (LAWS-03), drilled at an angle of $34^{\circ}$ from horizontal, initially had a length of $136 \mathrm{ft}$ and bottomed at a depth of $76 \mathrm{ft}$ bgs. However, the PVC shield rotated during installation such that scallops were at the top and rock debris repeatedly fell in, preventing liner insertion. While pulling the scalloped PVC to replace it with a perforated PVC shield that did not require orientation, the scalloped PVC broke and only $85 \mathrm{ft}$ was recovered. The hole was blocked at that position and could not be drilled out with the equipment available. Thus, LAWS-03 was completed at a length of $85 \mathrm{ft}$ and a depth of $40 \mathrm{ft}$ bgs. An absorbent liner was installed at the outset in preparation for the 2002 summer monsoon season. The entire monitoring site is enclosed inside a locked, 8-ft-high chainlink fence for security.

The liners used in the angled boreholes carry electrical wire pairs to detect soil-moisture changes. Surface-water data are provided by stream gages above and below the weir site. Depth of ponding behind the weir is provided by a gage installed just behind the structure. 



\section{INTRODUCTION}

A prescribed burn in the Bandelier National Monument in May 2000 went out of control and spread across the Pajarito Plateau. Known as the Cerro Grande fire, it was the most devastating wildfire in New Mexico to that date (Joseph 2001, 72662). A common consequence of fire is enhanced runoff in the damaged watersheds. For example, in Water Canyon above NM highway 501, the estimated post-fire peak discharge for one storm event of 840 cubic feet per second (cfs) dwarfs the pre-fire maximum of 0.3 cfs (Gallaher et al. 2001, 72662). In response to concern over the potential for enhanced runoff and transport of contaminant-laden sediment off site in the wake of the Cerro Grande fire, the U.S. Army Corps of Engineers constructed a low-head weir in Los Alamos Canyon near the White Rock "Y." The structure was designed to mitigate surface transport of contaminants adsorbed on sediment. However, the project neglected to consider subsurface transport, which is potentially enhanced by both the local geology and temporary ponding of water behind the weir.

The purpose of this report is to describe the installation by Los Alamos National Laboratory (LANL) of a monitoring site called the Los Alamos Weir Site (LAWS), on the south bank of Los Alamos Canyon, upstream of the weir. This work was funded by the Cerro Grande Rehabilitation Project (CGRP) to address near-and long-term activities required for LANL to fully recover from the Cerro Grande fire.

The site includes one vertical well and two angled boreholes extending out under the channel in Los Alamos Canyon (one at approximately $45^{\circ}$ and one at approximately $30^{\circ}$ from horizontal). The holes are located in the northeast corner of the paved parking lot near the White Rock "Y" (Figure 1). These holes will be used to monitor the impact of both the Cerro Grande fire and the weir on water quality beneath the canyon upstream of the structure. Table 1 gives the location and elevation of the well and boreholes.

Acronyms and abbreviations used herein are defined at the front of the document. A glossary at the back gives definitions of terms that may be unfamiliar to readers. Five-digit numbers in reference citations are ER's identification numbers for the documents cited. This facilitates location of copies on file in ER's Records Processing Facility.

\section{Hydrogeologic Setting}

Regional groundwater characterization wells R-9 and R-9i, located approximately $1 / 4$ mi. west of the weir, provide a good picture of the hydrogeology of this portion of Los Alamos Canyon (Broxton et al. 2001, 71250; Broxton et al. 2001, 71251). These wells were installed under the Hydrogeologic Workplan (LANL $1998,59599)$ to characterize the regional as well as any perched zones of saturation existing near the eastern Laboratory boundary. Well R-9 encountered four zones of saturation: two perched in the Cerros del Rio basalt, one perched in the Puye Formation and the one lying beneath the regional water table in Santa Fe Group basalt. The perched zones were sealed off and R-9 was completed with a single screen straddling the regional water table, which was encountered at a depth of $688 \mathrm{ft}$. Well R-9i was installed beside R-9 to permit monitoring of the perched zones in the basalt (Figure 2). Hydrologic testing at R-9i indicated the upper zone was much more productive than the lower zone (Table 2).

The conceptual hydrogeologic model for the weir site predicted that there would be two zones of perched saturation in the Cerros del Rio basalt, corresponding to those encountered at R-9i. The upper zone was anticipated to extend from a depth of 140 to $230 \mathrm{ft}$. The perching horizon was expected to be an interval of massive basalt. The lower zone was expected to extend from a depth of 264 to $282 \mathrm{ft}$. An 8-ft-thick clay interval overlying the so-called "old alluvium" was predicted to be the perching horizon for the lower zone. 
Table 1

Geodetic Data for the Well and Boreholes at the Weir Monitoring Site

\begin{tabular}{|c|c|c|c|c|}
\hline Well/Borehole $^{\mathrm{a}}$ & Bearing/Inclination & Easting $(\mathrm{ft})^{b}$ & Northing $(\mathrm{ft})^{\mathrm{b}}$ & ${\text { Elevation }(\mathrm{ft})^{\mathrm{C}}}^{\mathrm{C}}$ \\
\hline LAWS-01 (LA10135) & NA (vertical) & 1649524.5 & 1770854.0 & 6304.8 \\
\hline LAWS-02 (LA10136) & $\mathrm{N} 40^{\circ} \mathrm{E} / \sim 43^{\circ}$ & 1649536.913 & 1770848.298 & 6304.9 \\
\hline LAWS-03 (LA10137) & $\mathrm{N} 40^{\circ} \mathrm{E} / \sim 34^{\circ}$ & 1649542.9 & 1770848.8 & 6304.9 \\
\hline
\end{tabular}

${ }^{a}$ Number in parentheses is FIMAD ID number for well/borehole.

${ }^{b}$ NAD 83 Survey Coordinates for brass monument in concrete pad.

${ }^{\mathrm{C}}$ Above mean sea level.

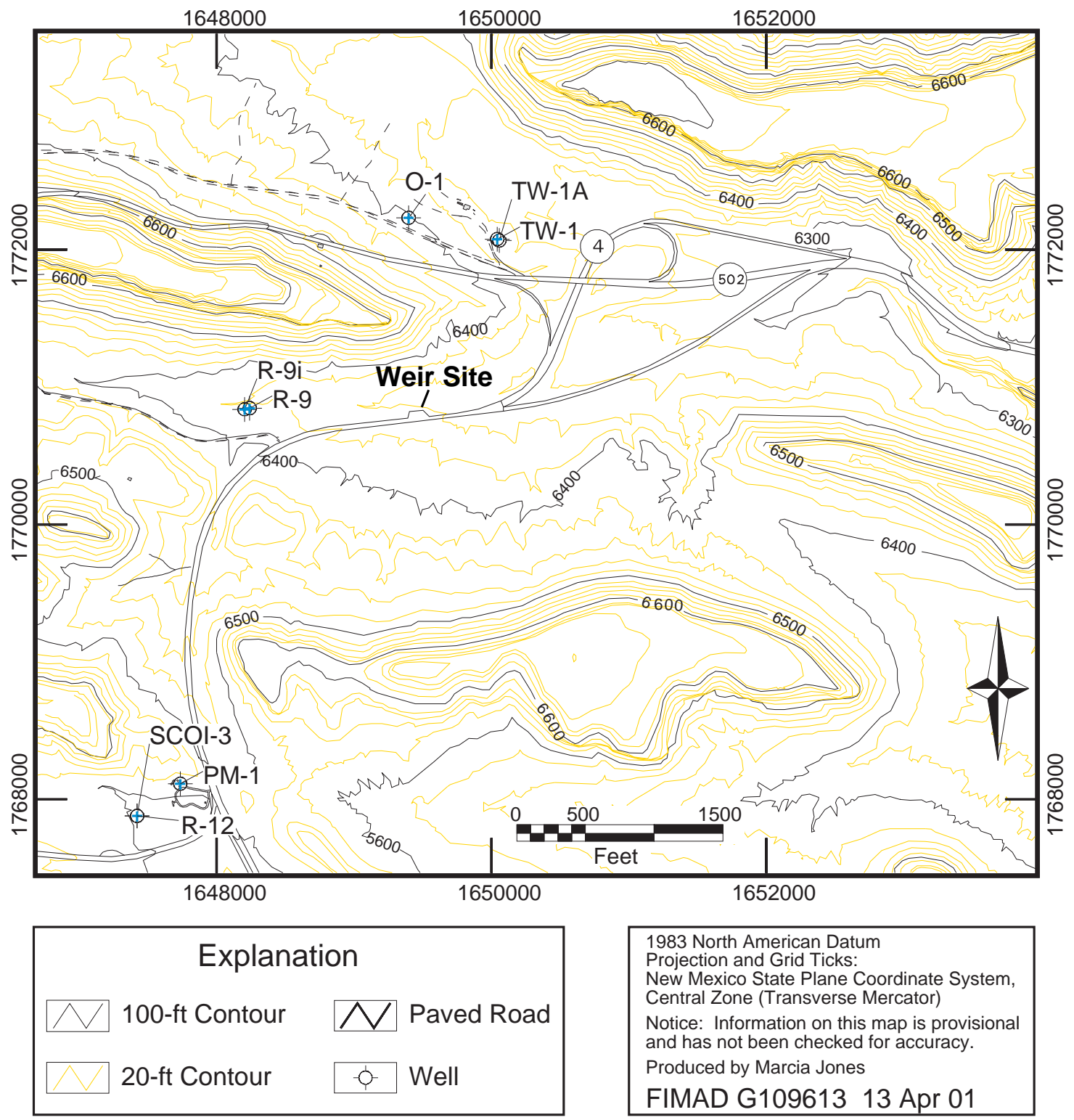

Figure 1. Location of the weir site 
Table 2

Summary of Straddle-Packer/Injection Testing at Characterization Well R-9i (modified from Broxton et al. 2001, 71251)

\begin{tabular}{|c|c|c|c|c|}
\hline Screen \# & $\begin{array}{c}\text { Depth } \\
(\mathrm{ft})\end{array}$ & $\begin{array}{c}\text { Injection rate } \\
(\mathrm{gpm})^{\mathrm{a}}\end{array}$ & $\begin{array}{c}\text { Volume } \\
\left({\text { (gal. })^{\mathrm{a}}}^{\mathrm{a}}\right.\end{array}$ & $\begin{array}{c}\text { Hydraulic Conductivity } \\
(\mathbf{f t} / \mathbf{d})^{\mathrm{b}}\end{array}$ \\
\hline 1 & $189-199$ & 11 & 120 & 37.07 \\
\hline 2 & $270-280$ & 19 & 30 & 0.79 \\
\hline
\end{tabular}

${ }^{\text {a }}$ From flow-meter readings.

b Based on analysis of test data using Bouwer-Rice method (Bouwer and Rice 1976, 64056).

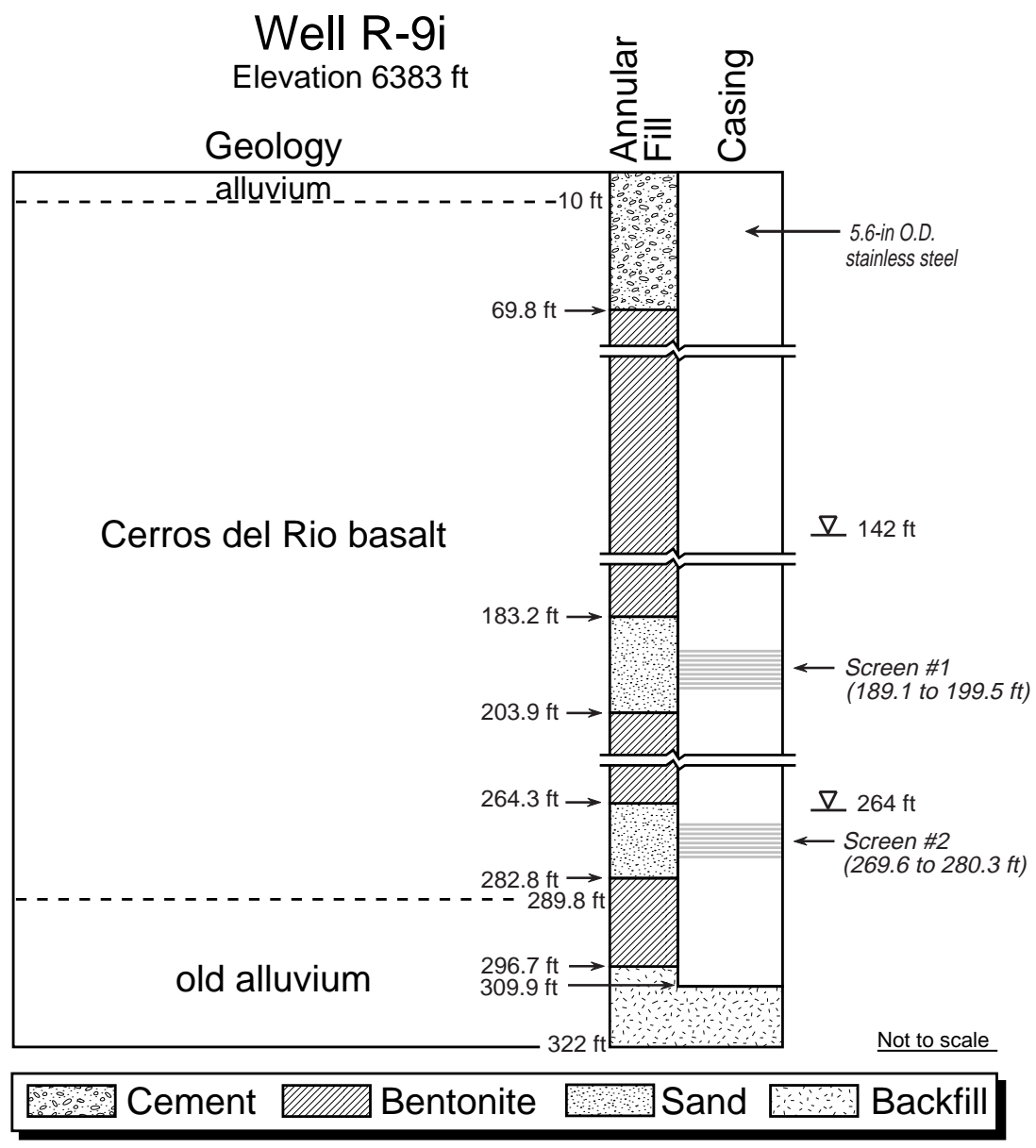

Figure 2. Hydrogeology and well construction at characterization well R-9i

\section{The Low-Head Weir}

The weir consists of a rock-and-mesh gabion situated downstream of a flat-floored channel area (Figure 3). The structure is classified as "low head" because water can pass through the gabion, and significant long-term ponding behind the weir should not occur. It was designed to cause particles larger than 80 microns in diameter to settle behind the weir. 


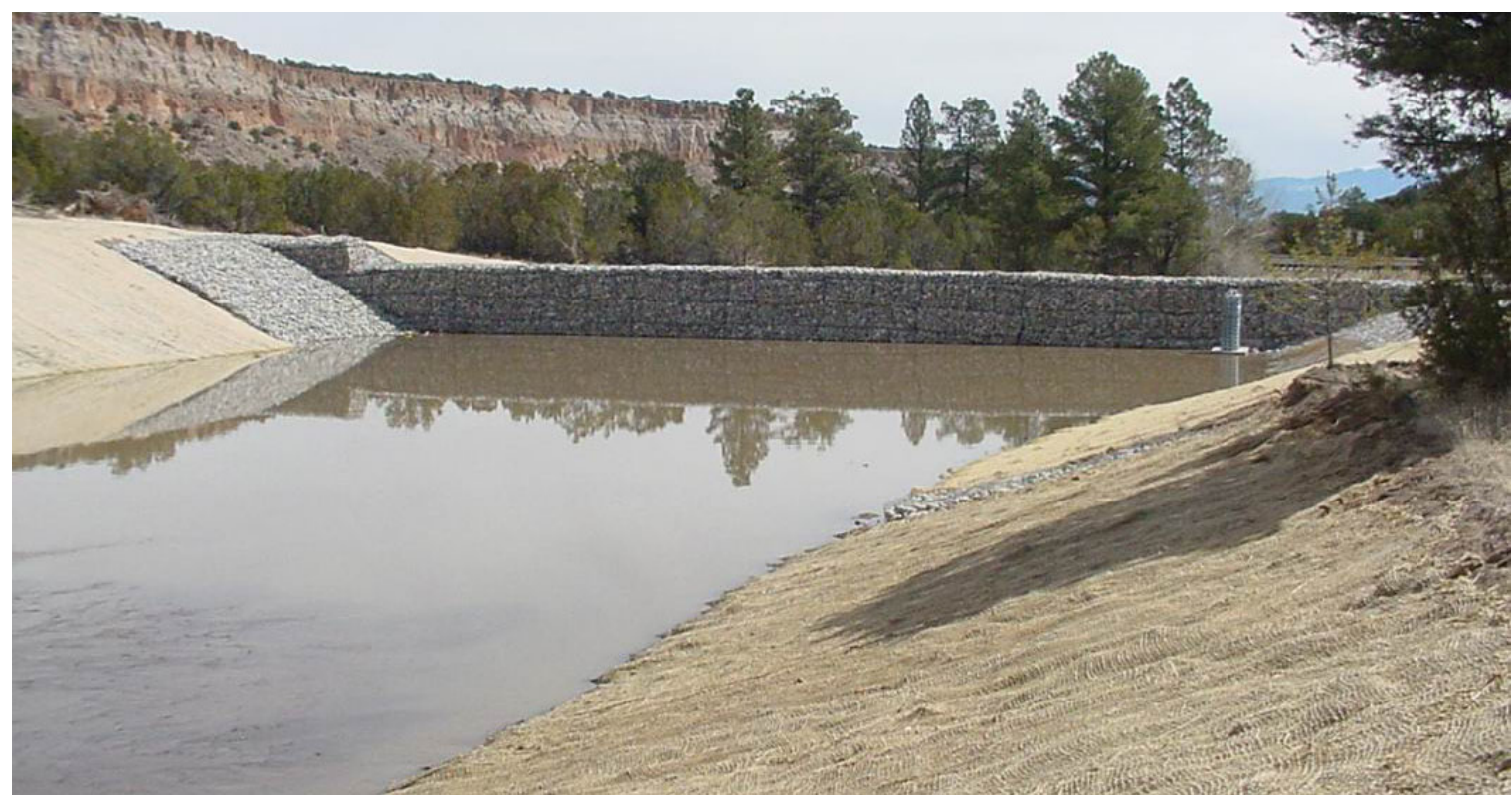

Figure 3. The Los Alamos Canyon low-head weir with ponded runoff (photo by Phil Stauffer)

Cerros del Rio basalt lies beneath a thin layer of alluvium at the site. Although the basalt is locally fractured and transmissive, under natural conditions the top of the unit is weathered and fractures are plugged with sediment. However, grading to flatten the channel upstream of the weir removed the alluvium and weathered basalt that tended to seal the fractures, thus facilitating the seepage of surface water into the basalt.

During such grading, mounds of basalt were encountered. As these mounds rose to a height above that planned for the flat area behind the weir, they were drilled in preparation for blasting so they could be removed. However, the San Ildefonso Pueblo expressed concern that the blasting could potentially affect sacred sites in the adjacent bluffs. In response to these concerns, the plans to remove the basalt mounds were abandoned and the blast holes were filled with cement grout. Consequently, the flat settling area upstream of the weir is approximately one-third of the size that was originally planned (Figure 4).

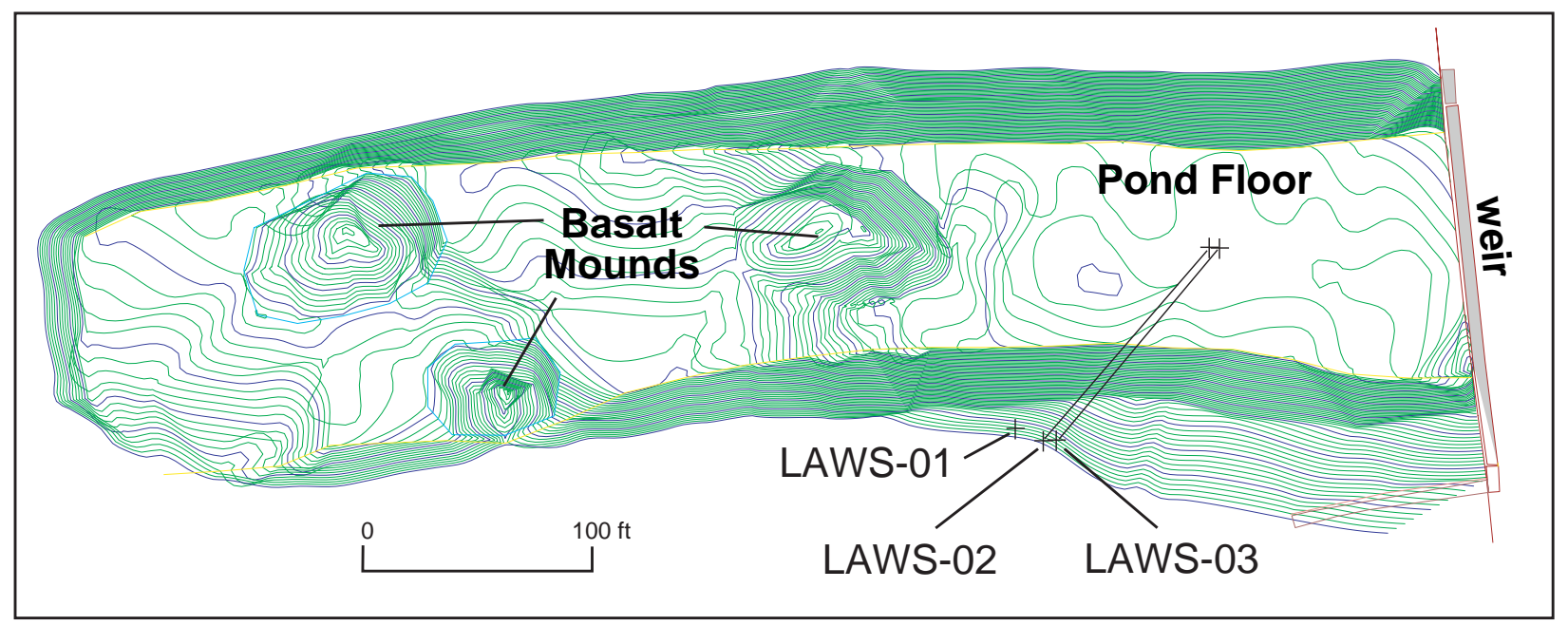

Figure 4. Detailed topographic map of the area behind the weir (prepared by Bill Kopp) 


\section{Monitoring Plan}

The hydrogeologic setting, together with the change in stream conditions produced by both the Cerro Grande fire and construction of the weir, prompted LANL to propose installing a site to monitor the impact of the fire and weir on subsurface water quality. Several factors led to the proposal:

- The known occurrence of perched water in the basalt at nearby wells (R-9/R-9i),

- The fractured nature of the basalt,

- The shallower depth and direct exposure of the basalt to runoff as a result of grading at the weir,

- The hydraulic head produced by even temporary ponding of water behind the structure, and

- The potential for contaminated surface water to enter the vadose zone and ultimately percolate to intermediate-depth perched zones of saturation in the basalt.

The monitoring site addresses four issues: (1) surface water/groundwater connection, (2) the impact of the fire, (3) the impact of the weir, and (4) hydraulic properties of the basalt.

The original monitoring plan called for drilling three boreholes upstream of the weir: one vertical at the edge of the channel and two slant holes (at $45^{\circ}$ and $30^{\circ}$ from horizontal) extending out under the channel (Figure 5). These were to be aligned so that they would be drilled in the same vertical plane. The vertical hole was to be completed as a monitoring well with a single screen in the lower perched zone. The $45^{\circ}$ hole was to be $380 \mathrm{ft}$ long and instrumented with a flexible liner for monitoring both the upper perched zone and the unsaturated zone above it. The $30^{\circ}$ hole was to be $150 \mathrm{ft}$ long and instrumented to monitor only the unsaturated zone above the upper perched water. Based on drilling conditions at R-9 and R-9i, it was assumed that the holes would stay open, facilitating deployment of flexible liners for monitoring.

However, as is often the case, the design of the well and boreholes changed in response to conditions encountered during their installation. Because we were prohibited from drilling through the asphalt in the parking lot and space for adding fill north of the pavement was limited, it was not possible to drill the holes toward the pond area in the same vertical plane. This change did not affect the project goals, since such alignment could not guarantee that the same fractures would be penetrated by both angle holes.

Nonetheless, the holes were placed as close together as practical while allowing enough space between them for well integrity and drilling-crew safety. Another change was warranted when it became clear that the vertical hole would not stay open and drilling had to be done by slower casing-advance methods. As a result, the slant holes were shortened and all saturated-zone tasks were moved to the vertical well (Figure 6). Furthermore, the use of flexible liners in the unstable angle holes required PVC shields (Stone 2002, 72663). 


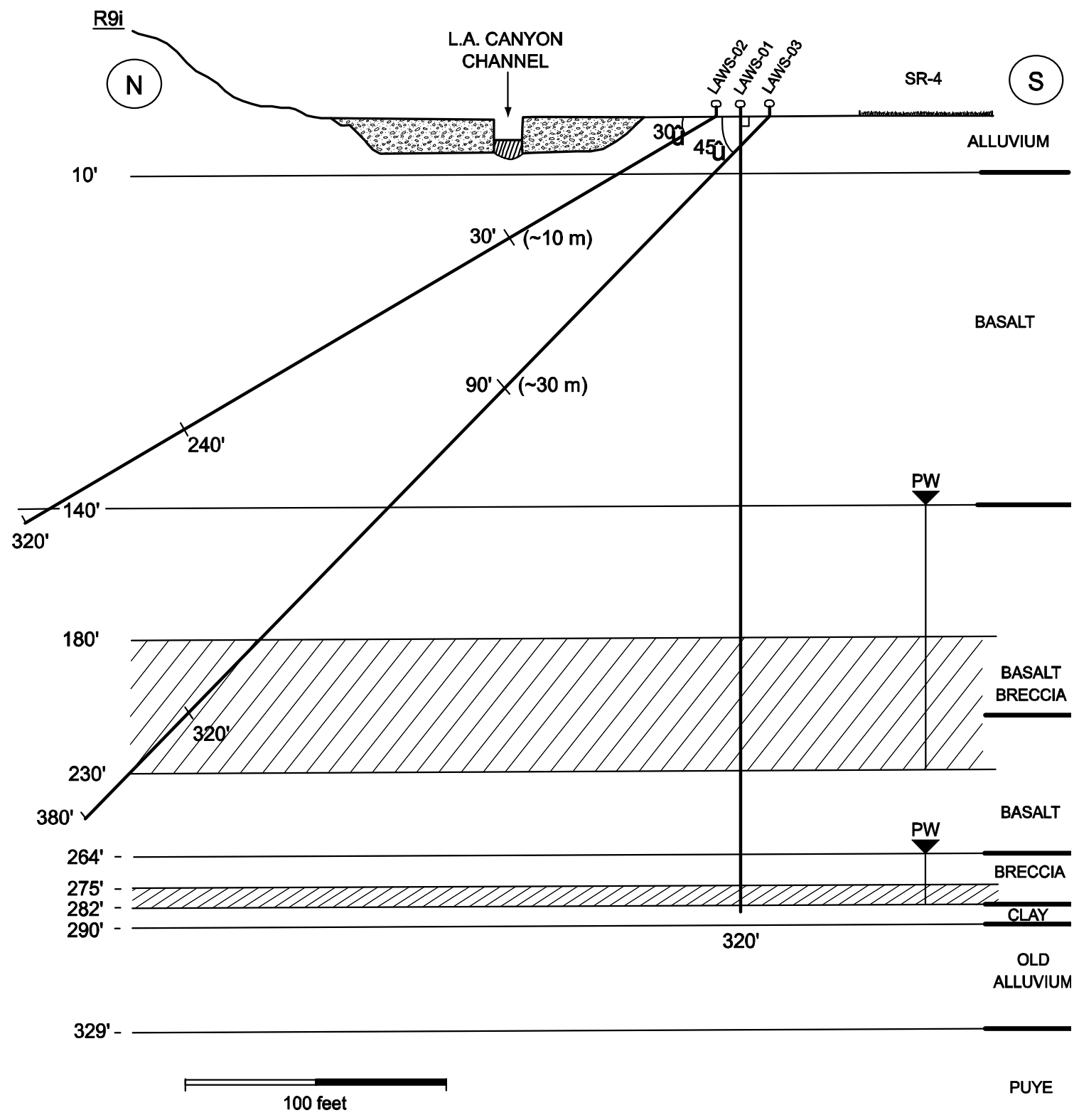

Figure 5. Planned design for well and boreholes 


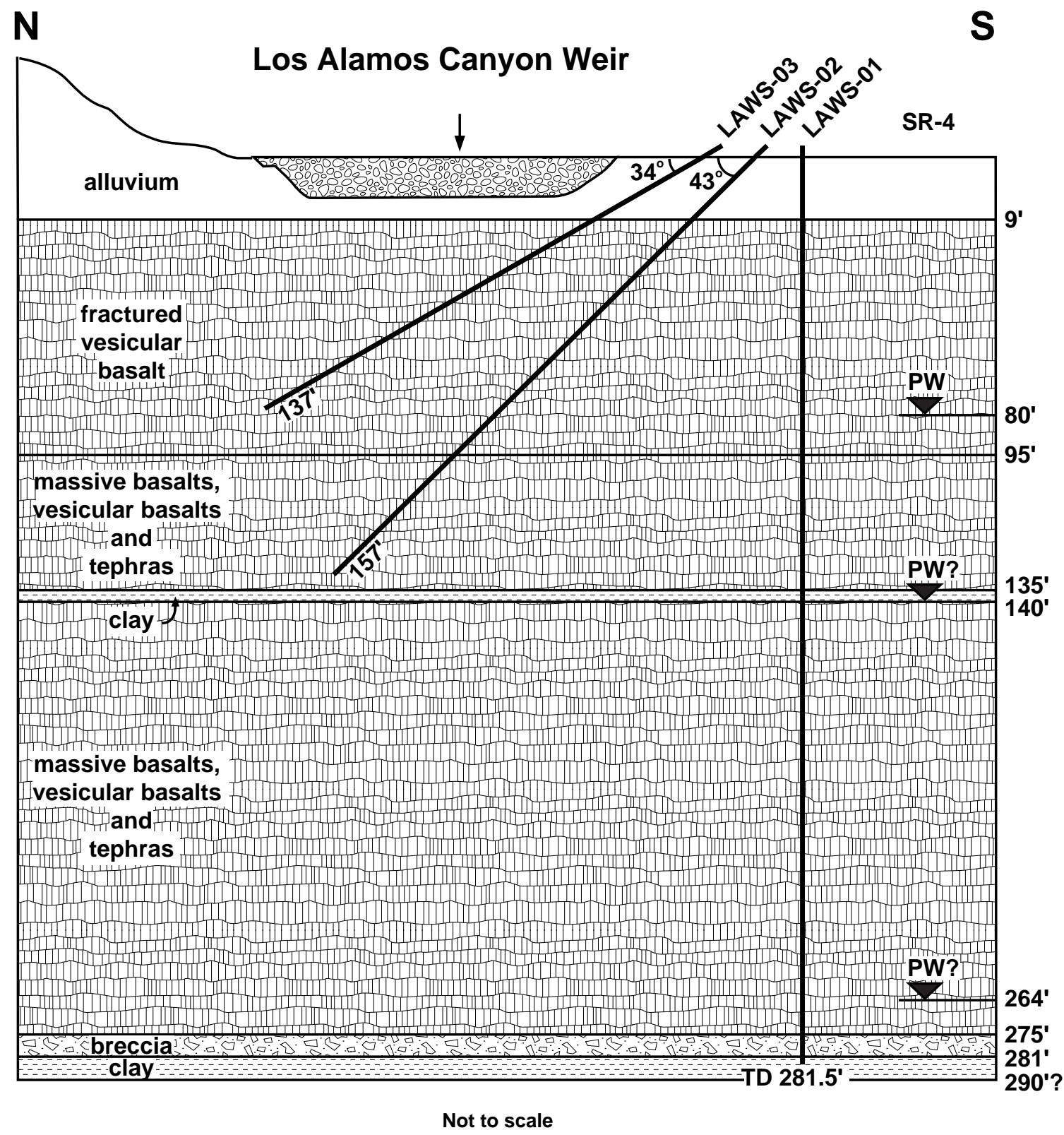

Figure 6. Actual configuration of well and boreholes

\section{Drilling Methods}

Drilling proceeded in two phases. First, Stewart Brothers Drilling Co. (SBDC) augered three 12-in. holes (one vertical and two angled) to the top of the basalt (approximately $9 \mathrm{ft}$ deep) using a CME-750 rig (Figure 7). SBDC then set $103 / 4$-in. outside diameter (O.D.) steel surface casing in these holes. Next, Dynatec Drilling, Inc. (DDI), drilled the basalt to total depth (TD) by air-rotary, casing-advance methods with a Schramm T685W Rotadrill (Figure 8). The additional work on the $30^{\circ}$ hole was accomplished with an underground drilling rig (UDR). No drilling fluid was used in any phase of drilling the holes. 


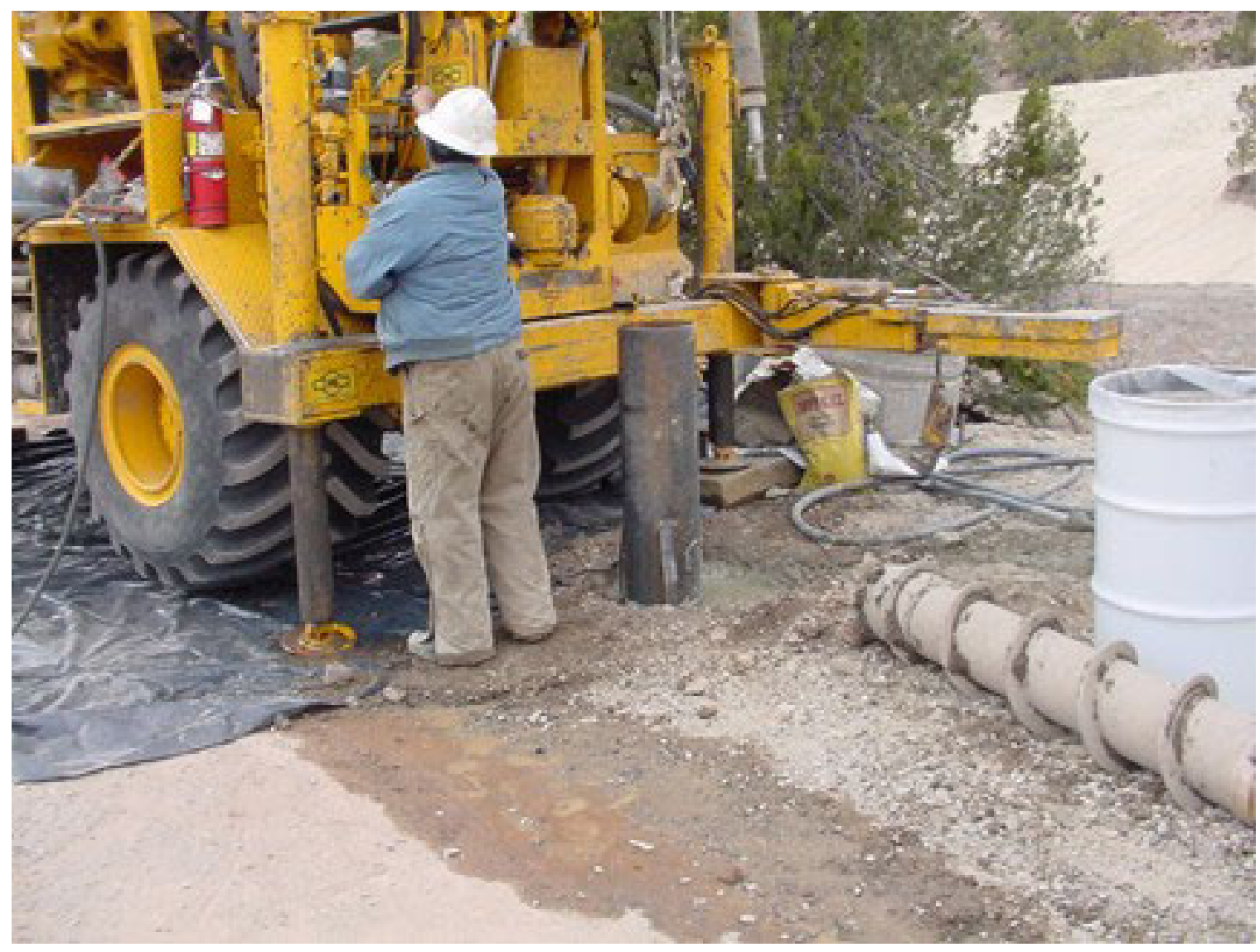

Figure 7. CME-750 auger rig setting surface casing at LAWS-01

\section{WELL LAWS-01}

LAWS-01 is the vertical hole, drilled to monitor the saturated zones at the weir site. It also provides a stratigraphic framework to which geologic observations from the angled holes can be referenced.

\section{Drilling LAWS-01}

The vertical hole was drilled by DDI using open-hole methods to a TD of $281.5 \mathrm{ft}$ within the clay zone responsible for perching water in the lower saturated zone. When we attempted to video log LAWS-01, the camera would not go deeper than $74 \mathrm{ft}$ because blocks of the highly fractured basalt had tipped into the hole. In one place the hole appeared to be square as a result of such collapse. The hole was cleaned out but would not stay open. So, it was redrilled by the casing-advance method, and the casing was left in the hole pending well construction. 


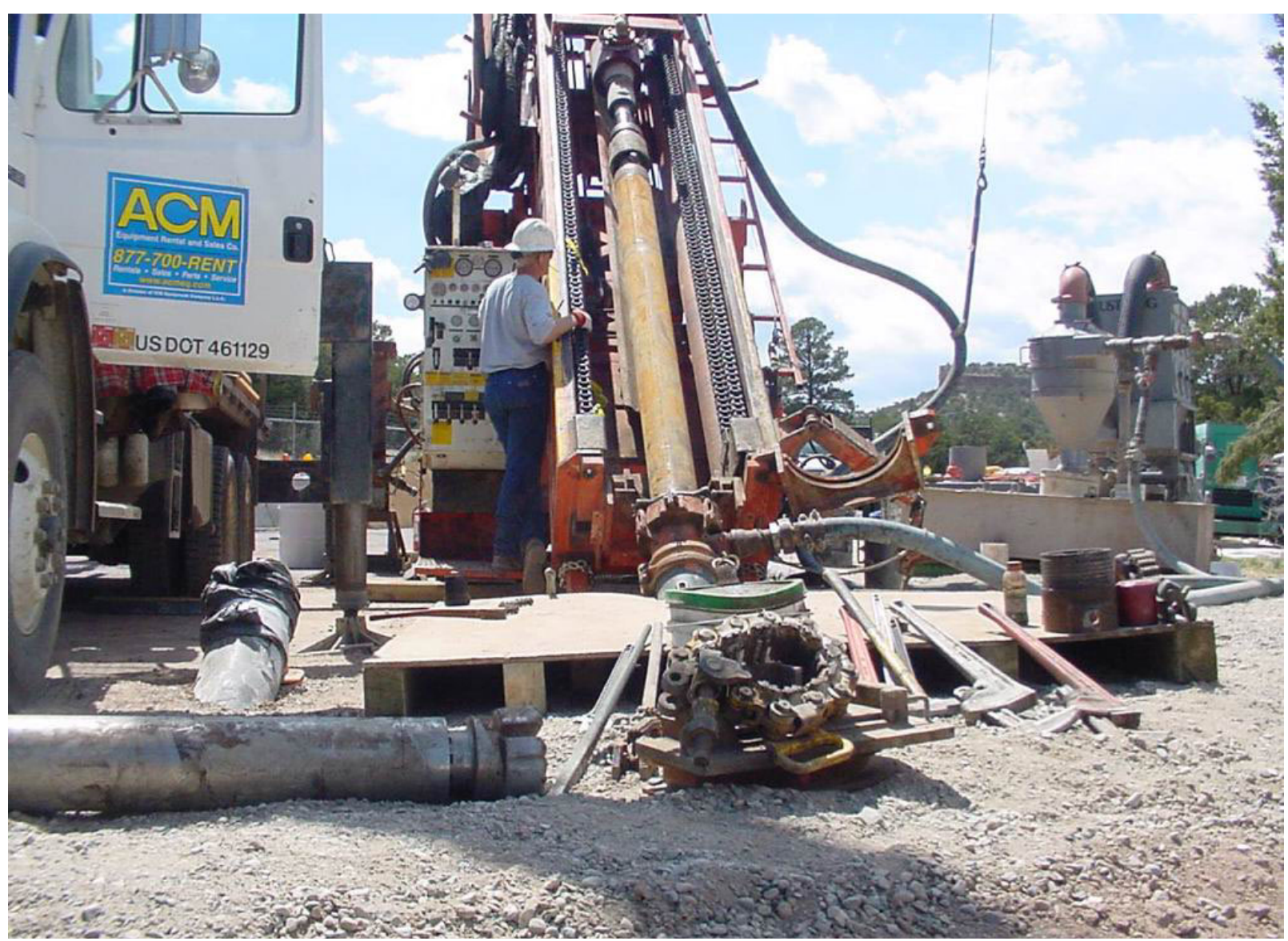

Figure 8. Schramm rotary rig drilling LAWS-02 by casing-advance method

\section{Hydrogeology at LAWS-01}

LAWS-01 mainly penetrates a sequence of lava flows in the Cerros del Rio basalt (Figure 9 and Appendix A). The upper $9 \mathrm{ft}$ of LAWS-01 includes fill, soil, and alluvium, respectively. The alluvium consists mainly of dacitic gravel up to cobble size. Vesicular olivine basalt extends from the base of the alluvium to a depth of $95 \mathrm{ft}$ bgs. Clay coatings and vesicle infillings as well as oxidized surfaces are common. Video logging in the open hole to $74 \mathrm{ft}$ bgs showed that the basalt is highly fractured. The fractures appear to be open and subvertical in orientation. Between $95 \mathrm{ft}$ and approximately $130 \mathrm{ft}$ is a mix of vesicular and massive layers of basalt. Matrix consisting of very fine-grained glass and black lithics occurs in the 95-100, 105-110, and 115-125 ft bgs intervals. The matrix is interpreted to be basaltic tephra, possibly marking individual eruptive events and flow boundaries. At a depth of $130 \mathrm{ft}$, the vesicular basalt is mixed with light brown smectitic clay. Clay increases in abundance to $135 \mathrm{ft}$, where a prominent clay horizon exists. The clay extends to a depth of $140 \mathrm{ft}$. From 140 to $145 \mathrm{ft}$, the clay horizon grades into massive basalt. Alternating vesicular and massive units extend to $275 \mathrm{ft}$ bgs. Multiple zones rich in tephra exist throughout this section, especially at 150-155, 185-190, 195-205, 220-225, 230-235, and 240-245 ft bgs. Tephras are associated with both vesicular and massive basalt intervals. A basaltic breccia horizon occurs between 275 and $281 \mathrm{ft}$ bgs. The breccia consists of vesicular and massive basalt chips with oxidized coatings and smectitic clay chips. At $281 \mathrm{ft} \mathrm{bgs,} \mathrm{a} \mathrm{clay/tephra} \mathrm{horizon} \mathrm{exists,} \mathrm{consisting} \mathrm{of} \mathrm{light}$ brown smectite clods with very fine-grained black lithics. We did not plan to fully penetrate this interval, as it is the perching horizon for the lower saturated zone. Thus, its thickness is not known at the weir. 
Construction Summary

Location: White Rock "Y" parking lot, adjacent to lower Los Alamos Canyon low-head weir

NAD 83 Survey Coordinates (Brass Pin):

N 1770854.0

E 1649524.5

Elevation $6304.8 \mathrm{ft}$

Drilling:

Phase 1: $3 / 28,01$ Augering to set surface casing

TD $9 \mathrm{ft}$

Phase 2: 4/4/01 - 4/11/01 Air-rotary-casing

advance; dual wall reverse circulation

TD $281.5 \mathrm{ft}$

Data Collection:

Borehole Logs - lithologic, video, natural gamma, epithermal neutron

Well Construction: 4/18/01 - 4/21/01

4 screen completion; $4.5 "$ OD Schedule 80

PVC, flush jointed; 0.01 " slotted 10 ' screens;

$9^{\prime}$ of $10.75^{\prime \prime}$ OD steel surface casing

Screen 1: 83 - $93 \mathrm{ft}$ bgs

Screen 2: 158 - $168 \mathrm{ft} \mathrm{bgs}$

Screen 3: 188 - $198 \mathrm{ft}$ bgs

Screen 4: 263 - $273 \mathrm{ft}$ bgs

Annular fill:

Primary filter pack: $20 / 40$ sand, nominally $5^{\prime}$

above and below screen

Secondary titter pack: $30 / 70$ sand, nominally 2

above and below primary sand pack

Backfill: bentonite chips and pellets

Surface seal: cement

Development: 5/2/01 - 5/3/01

Bailing - entire well volume

Final water quality parameters: turbidity $=5.9$

NTU, $\mathrm{pH}=7.52$, conductivity $=0.334 \mathrm{mSicm}$,

D. $0 .=4.81 \mathrm{mg} n, T=12.3 \mathrm{C}$, Salinity $=0.01 \%$

Sampling Instrumentation: WATERFLUTe membrane with four transducers and four sampling ports.

Port 1: $88 \mathrm{ft}$ bgs

Port 2: $162 \mathrm{ft}$ bgs

Port 3: $193 \mathrm{ft}$ bgs

Port 4: $268 \mathrm{ft}$ bgs
LAWS-01

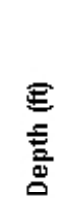

-

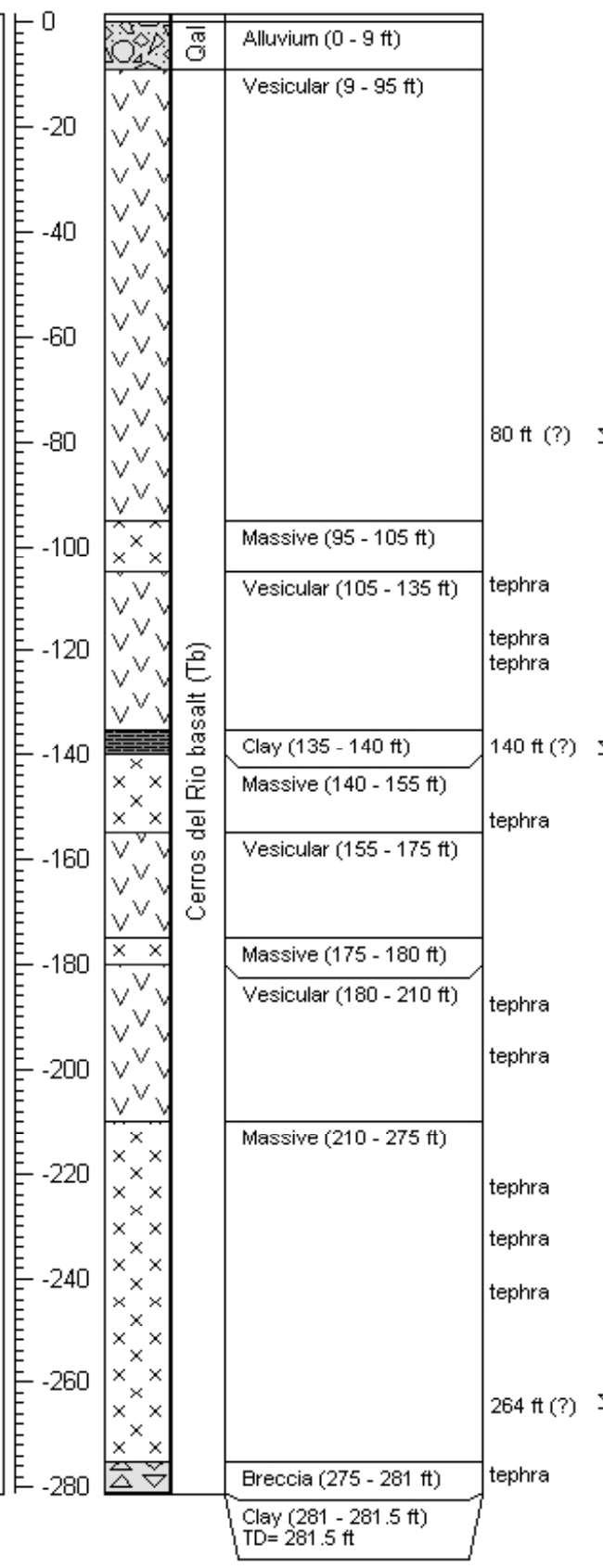

Lithology

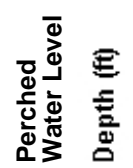

Well Construction

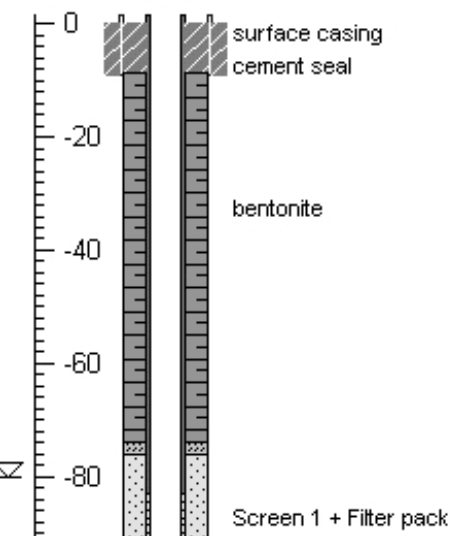

Screen 1 + Filter pack

Screen $2+$ Filter pack bentonite

Screen $3+$ Filter pack

bentonite $E-260$ E

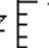

\section{Figure 9. Geology, construction, and perched water levels at LAWS-01}


While the vertical hole was being drilled, saturated conditions were first encountered at a depth of $80 \mathrm{ft}$ (Figure 9). This is $60 \mathrm{ft}$ above the position anticipated for the upper perched zone, based on data gathered at characterization well R-9i. The amount of water decreased with depth, and cuttings were dry between 100 and $105 \mathrm{ft}$. This perched water may be related to seepage of the water that was ponded behind the weir when drilling began. There had been standing water behind the weir for 1 to 2 months before drilling commenced. The position of deeper perched water was masked by drainage from this upper zone. All cuttings below a depth of $105 \mathrm{ft}$ bgs were wet. Thus, perched water levels shown on Figure 9 are estimates, based on observations at R-9i.

\section{Construction of LAWS-01}

The vertical hole was completed as a conventional monitoring well with four $10-\mathrm{ft}$ screens and a $10-\mathrm{ft}$ sump (Figure 9). The production casing is 4.5-in. O.D., Schedule 80 PVC. The screens are 0.01-in. slotted PVC. Primary filter pack (20/40 sand) was installed from $5 \mathrm{ft}$ below to $5 \mathrm{ft}$ above the screens. To keep bentonite from reaching the primary filter pack and eventually the screen, we emplaced secondary (finer) filter pack ( $40 / 70$ sand) $2 \mathrm{ft}$ below and above the primary filter pack. The space between screens (that is, between secondary filter packs) was filled with bentonite pellets and chips. Some EZ-MUD® was added to the bentonite to delay hydration during placement through the tremie pipe.

The well was to be developed by bailing and, if necessary, pumping. A video log made prior to bailing revealed that EZ-MUD® was coating the screens. The water in the initial bail had a turbidity value beyond the range of the instrument. Initial values for other field parameters included a pH of 6.28, a temperature of $13.5^{\circ} \mathrm{C}$, and a specific conductance of $455 \mu \mathrm{S} / \mathrm{cm}$. After bailing for $8 \mathrm{hrs}$ (on 3 May 01) turbidity was still high: 93 nephelometric turbidity units (NTU). The well was allowed to rest overnight and bailing resumed the next day. Water in the initial bail on 4 May 01 had a turbidity of 9.5 NTU so bailing continued. During the shift, the well would periodically bail dry. Water bailed as the well was going dry had elevated turbidity values because of disturbance of fines in the sump. The well was allowed to rest after going dry and then bailing resumed. After approximately $5 \mathrm{hrs}$ of bailing, the turbidity stabilized at 5.9 NTU. As the target was less than 5 NTU and other field parameters had also stabilized, the well was considered developed without pumping.

\section{Instrumentation of LAWS-01}

LAWS-01 was instrumented with a flexible liner (Water FLUTe ${ }^{T M}$ ) carrying four transducers and four sampling ports (Appendix B). Figure 10 shows the theoretical deployment of a Water FLUTe ${ }^{\mathrm{TM}}$ system. Figure 11 shows the installation of such a system at LAWS-01. Table 3 gives the specific location of ports for the liner installed in well LAWS-01. Although the transducers were placed near each other at the bottom of the well (at depths of 265-268 ft), each monitors a specific screen at shallower depths by means of tubing (Table 3). More specifically, one transducer is connected to the upper screened interval to monitor the seasonal upper saturation beneath the pond. Two are connected to the middle perched zone (corresponding to upper zone at R-9i) to determine whether this water is confined, as considered possible by some from R-9/R-9i data. The fourth transducer is associated with the bottom screen to measure head in the lower perched zone. 


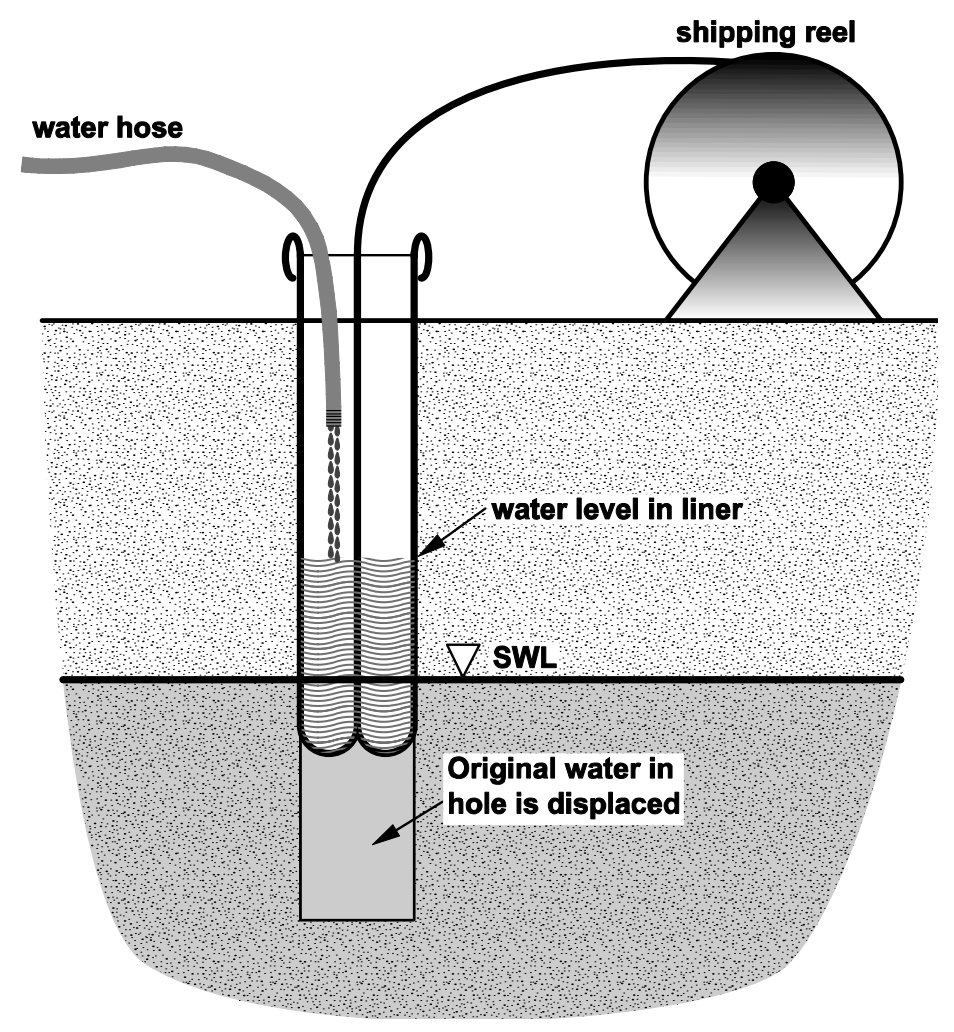

Figure 10. Schematic diagram showing deployment of a Water FLUTe ${ }^{\mathrm{TM}}$ system; water inside liner is isolated from the natural groundwater

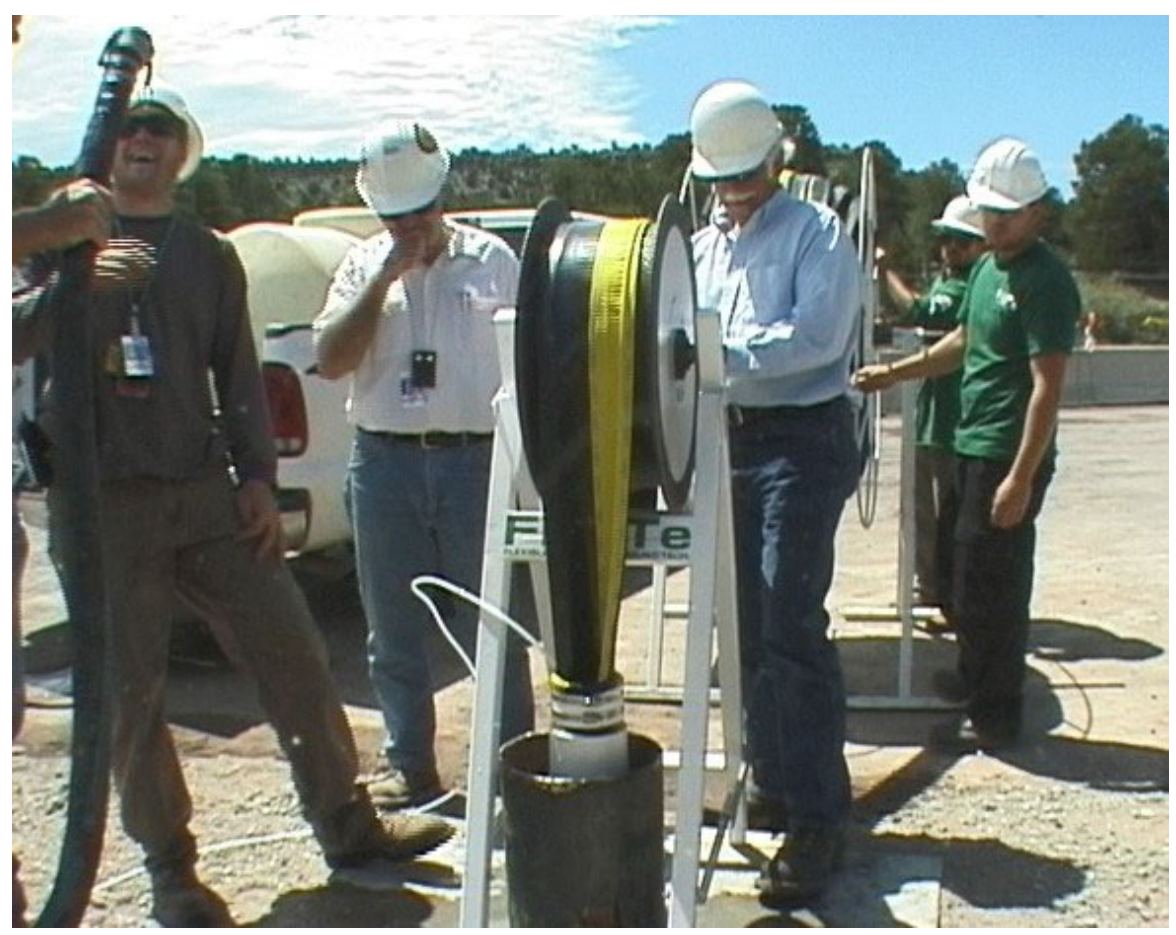

Figure 11. Installing the Water FLUTe ${ }^{\mathrm{TM}}$ system at LAWS-01; hose at left will deliver water to the inside of the liner for everting it into the well 
Table 3

Depth of Sampling and Transducer Points in LAWS-01

\begin{tabular}{|c|c|c|c|c|}
\hline Screen \# & $\begin{array}{l}\text { Screen Depth } \\
\text { (ft) }\end{array}$ & $\begin{array}{l}\text { Port in } \\
\text { Liner }^{a}\end{array}$ & $\begin{array}{l}\text { Port Depth } \\
\text { (ft) }\end{array}$ & 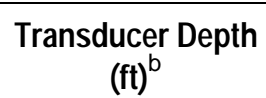 \\
\hline 1 & $83-93$ & 1 & 88 & 265 \\
\hline 2 & $158-168$ & 2 & 163 & 266 \\
\hline 3 & $188-198$ & 3 & 193 & 267 \\
\hline 4 & $263-273$ & 4 & 268 & 268 \\
\hline
\end{tabular}

${ }^{a}$ Screens are sampled by means of these ports in the flexible liner.

${ }^{b}$ Transducers are set at depths indicated but read water levels at the associated port.

At the time of instrumentation, the composite water-level depth was $174 \mathrm{ft}$. Thus, there was $104 \mathrm{ft}$ of water in the well. The flexible liner was filled with municipal water to a depth of $74 \mathrm{ft}$ bgs, creating $100 \mathrm{ft}$ of excess head in the liner. This facilitated deploying the liner through standing water. More importantly, it also provided the pressure necessary to keep the liner tightly sealed around screens assuring their isolation. As the final step in installation, tubes to each sampling port were purged by connection to a tank of nitrogen. This revealed that the upper screen was dry at the time of liner emplacement.

\section{BOREHOLE LAWS-02}

LAWS-02, the so-called " $45^{\circ}$ " hole, provides the means to monitor the saturation encountered at a depth of $80 \mathrm{ft}$ as well as that comparable to the uppermost perched water at R-9i and as well as the unsaturated zone above it.

\section{Drilling LAWS-02}

LAWS-02 was actually drilled at an angle of $43^{\circ}$ from horizontal. It is inclined out under Los Alamos Canyon at an azimuth of approximately $\mathrm{N} 40^{\circ} \mathrm{E}$. Once we discovered that the vertical hole would not stay open, we decided to drill the slant holes by casing-advance methods from the outset (after holes were augered to the basalt). LAWS-02 is $156 \mathrm{ft}$ long, taking it to a depth of $106 \mathrm{ft}$ bgs.

\section{Hydrogeology at LAWS-02}

The geologic section encountered at LAWS-02 is very similar to that at LAWS-01 (Figure 12 and Appendix A) because of their proximity. The hole penetrated approximately $7 \mathrm{ft}$ of fill, soil, and alluvium, respectively, comparable to the thickness of these materials at LAWS-01. Vesicular olivine basalt underlies the alluvium to an extent (along the inclined hole) of $156 \mathrm{ft}$ bgs. Two thin intervals of massive basalt were encountered at a depth bgs of 65-69 ft and at a depth bgs of 76-83 ft. Vesicular basalt, rich in clay and tephra, occurs from $90-100 \mathrm{ft}$ along the borehole.

No water was detected in the cuttings during drilling of LAWS-02. This is puzzling since we encountered water at a depth of $80 \mathrm{ft}$ in the adjacent vertical hole (LAWS-01). Three possible explanations come to mind: (1) the borehole didn't encounter any productive fractures, (2) the casing-advance drilling method sealed them off, or (3) the volume of water in the 80 -ft zone of saturation may have been small and was completely drained away during drilling of the vertical hole. 


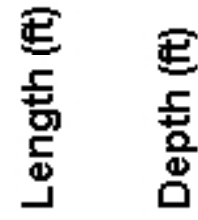

$E^{0}-0$

E -10 E

$$
\text { 音 }
$$<smiles>FC(F)(F)F</smiles>

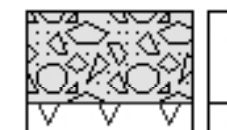

Fill and alluvium (dacite gravel)

Vesicular basalt

\section{Lithology}

Unit

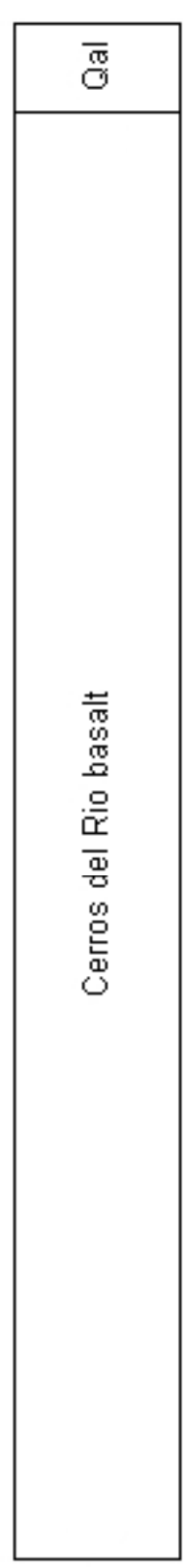

Figure 12. Geology along angled borehole LAWS-02 


\section{Construction of LAWS-02}

Construction of the angled holes at the weir site presented a problem. Since the ground was found to be unstable, the holes had to be kept open when the casing was pulled. However, flexible liners, as planned for use in the slant holes, need to be in direct contact with the rock in the borehole wall. Although liners do not work through the small openings associated with screens, we expected that they would work through larger openings. Thus, we decided that a scalloped casing or shield would be inserted, before pulling drill casing, to keep the hole open while permitting the liner to contact the rock (Figure 13). More specifically, we installed 6-in., schedule-80 PVC, in which 30-in. long scallops had been cut on one side with a band saw at 6-in. intervals (three in each 10-ft piece). As a measure against separation, the threaded connections were secured with sheet-metal screws through both PVC joints. The as-built diagram for LAWS-02 is given in Appendix C.

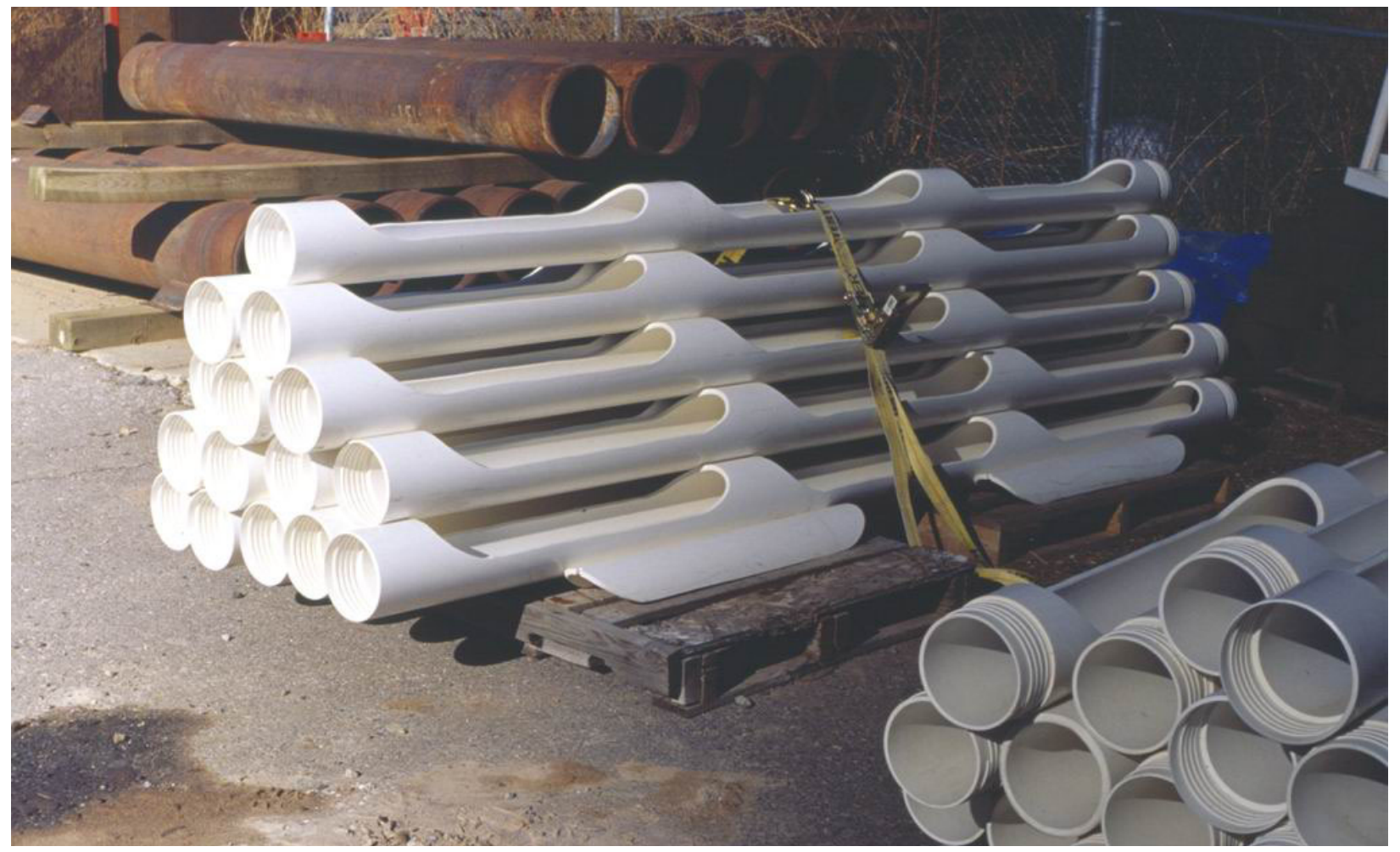

Figure 13. Scalloped PVC shield for liners in LAWS-02

Every effort was made to emplace the PVC with the scallops at the bottom to avoid the possibility of rock debris falling in when the casing was retrieved (Figure 14). However, because considerable weight had been removed by cutting the scallops, the PVC would not stay in the intended orientation (i.e., scallops down). This problem was remedied by alternating scalloped lengths of PVC with blank lengths. This arrangement reduced the number of openings along the borehole but returned enough weight that the PVC no longer immediately rolled scallops-up when inserted through the steel casing. However, some rotation of the PVC when the casing was pulled was unavoidable, and thus the scallops were positioned between 6 o'clock (at the bottom of the hole) and 3 o'clock. As the scallops were not on the top, caving was not a problem. The steel casing was pulled without the use of jacks. Once the casing had been pulled back far enough for the PVC to extend beyond it, the basalt collapsed enough to hold the PVC in place. 


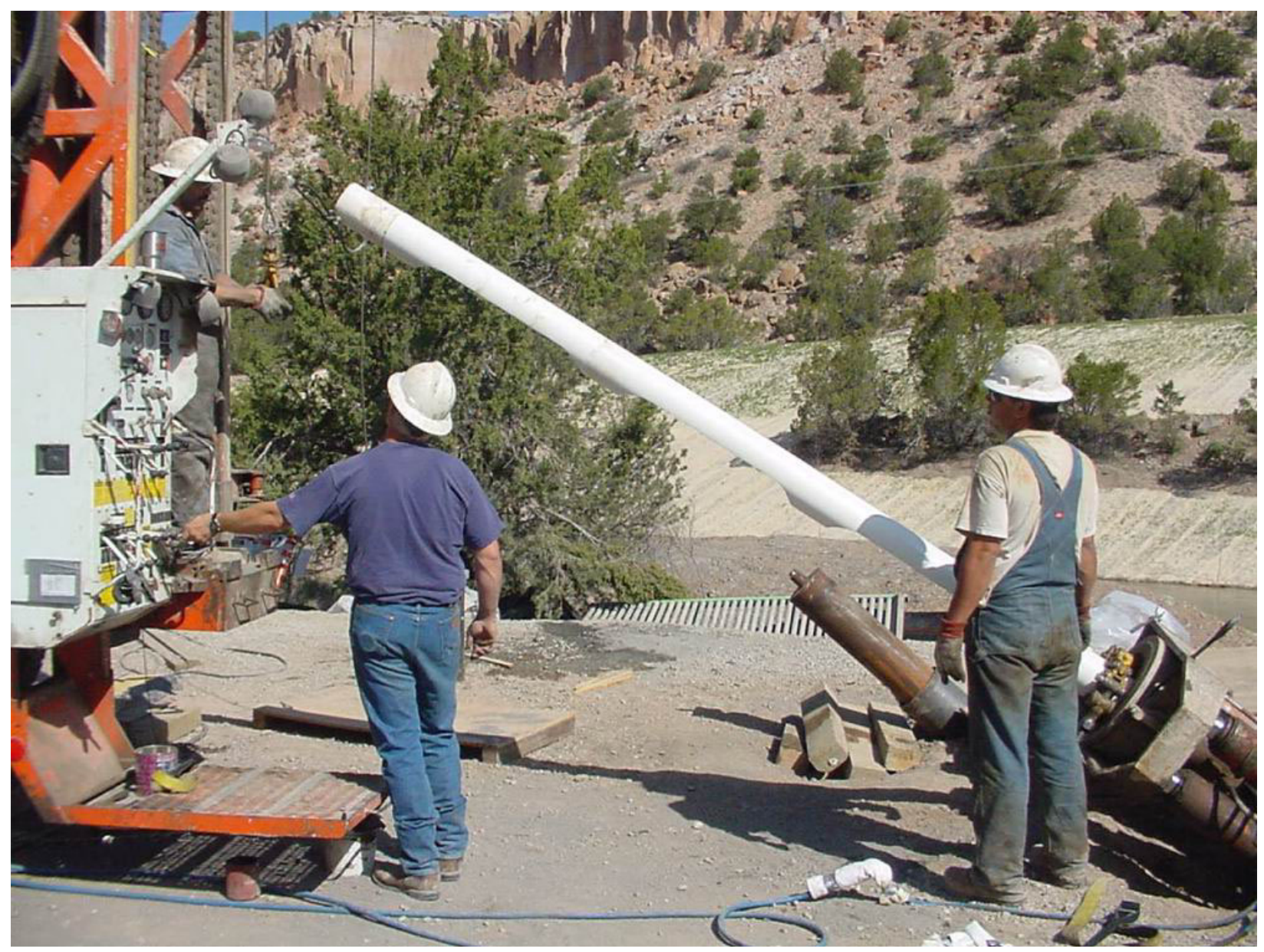

Figure 14. Constructing LAWS-02 with scalloped PVC

\section{Instrumentation of LAWS-02}

Original plans called for dual liners in an open borehole. However, as the ground was unstable and a PVC shield with scallops on one side was required, it was practical to install only a single liner.

A 6-in. diameter liner, consisting of color-reactive (red crepe) paper covered by soft, white cotton cloth, was installed first to detect moisture-bearing zones. Normal eversion of the liner by inflation was unsuccessful because of the size and location of the scallops. The liner became lodged against the lower edge of the first scallop it encountered and then tried to evert out through the opening into the sizable annulus existing between the PVC and the borehole wall, especially at local washouts.

To overcome the annulus problem, an 11-in. diameter liner was deemed large enough to expand through the scallops out to the borehole wall when inflated (except in washouts). To facilitate installation, we inserted it into the hole uninflated (Figure 15). To get past the scallops, we bundled and tied it at intervals with weak string. To streamline the bottom of the liner, we placed a short interval in a Tyvek ${ }^{\mathrm{TM}}$ sleeve attached to the end of a 1-in. PVC ramrod. A centralizer on the ramrod kept the liner from deflecting out the scallops. When the liner was partially inflated, the string broke and the ramrod, sleeve, and centralizer were recovered. Installation was completed by fully inflating the liner. 


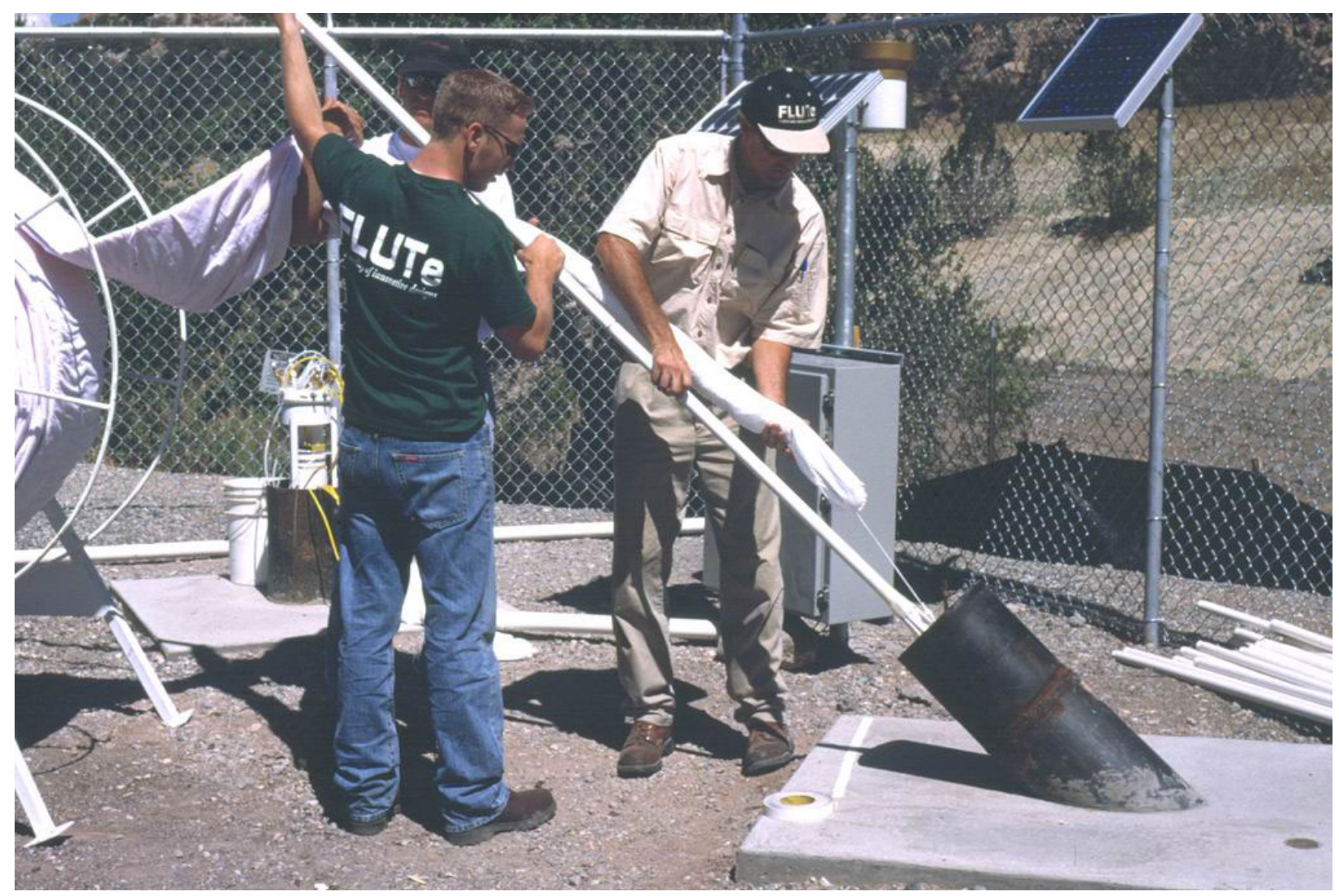

Figure 15. Installing the color-reactive liner in LAWS-02

The presence of water in the borehole walls is signaled by means of electrical wire pairs placed at regular intervals along the liner (see Appendix C). As LAWS-02 extends below the depth of the 80 -ft perched water zone, it can be alternately instrumented with liners to monitor unsaturated and saturated parameters, depending on conditions. An adsorbent liner is used for unsaturated conditions. Such a liner was installed after the color-reactive liner was removed, in anticipation of runoff during the monsoon season of 2002. The liner for saturated conditions would carry sampling ports.

\section{BOREHOLE LAWS-03}

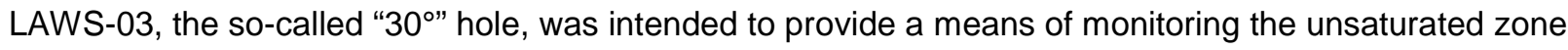
immediately beneath the pond and above the seasonal (?) 80-ft-deep perched zone of saturation.

\section{Drilling LAWS-03}

LAWS-03 was actually drilled at an angle of $34^{\circ}$ from horizontal. Like LAWS-02, it was drilled by airrotary, casing-advance methods. As initially drilled, LAWS-03 was $136 \mathrm{ft}$ long. That took it to a depth of $76 \mathrm{ft}$ bgs. Caving problems reduced the completed length and depth, as discussed below. 


\section{Hydrogeology at LAWS-03}

The geologic sequence is essentially the same as seen in the other two holes (Figure 16 and Appendix A). LAWS-03 penetrated approximately $7 \mathrm{ft}$ of fill/topsoil/alluvium, respectively, and $70 \mathrm{ft}$ of Cerros del Rio lavas. The lavas are primarily vesicular olivine basalts, like those found in LAWS-01 and LAWS-02. Tephra matrix between depths bgs of 62 and $73 \mathrm{ft}$ is associated mainly with vesicular basalt but also with a small interval of massive basalt.

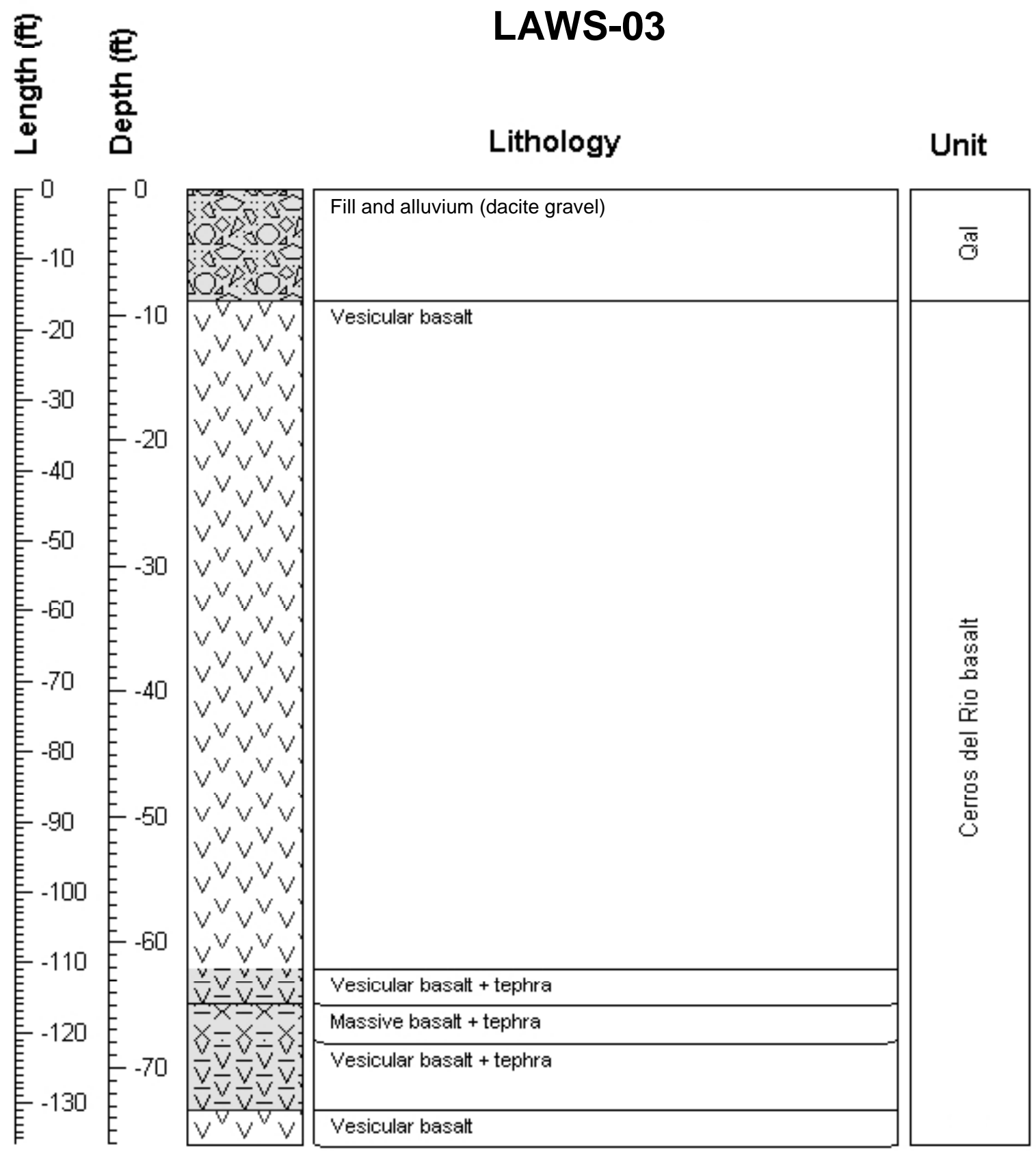

Figure 16. Geology along angled borehole LAWS-03 
As in LAWS-02, no saturation was encountered in LAWS-03. This is not surprising as it ended above even the 80 -ft perched interval.

\section{Construction of LAWS-03}

The construction of LAWS-03 involved two phases: one with a scalloped PVC shield, as deployed at LAWS-02, and one in which the upper part of scalloped PVC was retrieved and replaced with a perforated PVC shield covered with wicking fabric.

Scalloped PVC. Scalloped PVC was emplaced in LAWS-03 prior to withdrawing the casing, as had been done at LAWS-02. However, at LAWS-03, jacks were required to pull the casing. The PVC tended to twist more when casing was pulled than it had at LAWS-02. Thus, although the PVC was installed with scallops at the bottom, it rotated such that many of the scallops shifted to a position at or near the top of the angle hole.

Video logging of the hole after the scalloped PVC shield had been emplaced showed an obstruction at a depth of $77 \mathrm{ft}$. It appeared to consist of some spoil and a rock that had fallen in through one of the scallops. Various attempts, described below, were made before this blockage was cleared.

- First, the obstruction was further investigated by running a 1-in. PVC rod with an end cap into the scalloped PVC by hand. Although we could push the small-diameter rod past the obstruction to TD, we could not dislodge it.

- Then, we inserted a 2-in. PVC rod with an end cap into the scalloped PVC in an effort to knock the rock loose. However, the rock would not budge.

- Next, a 2-in. vacuum line was run into the hole. This method successfully removed loose spoil but not the rock. Another video log was made to characterize the obstruction once the spoil had been removed.

- Based on a meeting with drilling personnel, during which the video was shown, we decided to run a length of B rod with a 4-ft, 1/2-in. O.D. stainless steel "stinger" attached to the bottom into the hole by means of the Smeal rig. However, as that rig could not provide any pulldown, the operation was unsuccessful and was abandoned. During the operation, however, the stinger went out through a scallop, lodged itself in the borehole wall, and sheared off at approximately $80 \mathrm{ft}$ downhole.

- Next, we attempted to dislodge the obstruction by means of a bi-cone bit at the end of the B rod. This, too, was unsuccessful.

- The Schramm drill rig was returned to the site. After a few short bursts with a 4 1/2-in. O.D. downhole-hammer bit at the end of $41 / 2$-in. RC rods, the blockage was finally cleared.

- The drill string was run down the rest of the hole to a length of $126 \mathrm{ft}$. The hole was found to be clear. Video logging confirmed that the rock had been cleared. However, about $1 \mathrm{ft}$ of the lost "stinger" was seen extending into and upward along the inside of the PVC.

When we attempted to install an 11-in., color-reactive liner, uninflated with a PVC ramrod, as had been done in LAWS-02, we encountered an obstruction at $77 \mathrm{ft}$ along the PVC: the same position as the previous blockage. Fortunately, the Schramm rig was still at LANL and was brought back on-site to clear the hole. Then, we installed a sleeve of smaller diameter PVC (4-in. I.D.) inside the $61 / 2$-in. PVC to a position past the scallop where caving was occurring.

Tests by FLUTe ${ }^{\mathrm{TM}}$, Inc., showed that the 11-in. liner could be deployed as in the other angle hole and everted while inflated, despite the smaller diameter of the PVC sleeve. However, the liner could not be installed beyond a distance along the borehole of $85 \mathrm{ft}$, the position of the next scallop beyond the sleeve. 
Thus, the liner was withdrawn and instrumentation of LAWS-03 was deferred until the borehole could be made ready for a liner.

Perforated PVC. On 20 February 2002 we decided that the scalloped PVC shield should be removed and a different shield that did not require orientation in the borehole should be installed. The replacement shield was made of 6 1/2-in. schedule-40 PVC in which 2-in. holes had been drilled in two intersecting spiral patterns (Figure 17 and Appendix C). To enhance collection of soil water at LAWS-03, we wrapped the perforated PVC with a layer of felt wicking fabric in discrete segments so that the source of any water collected could be identified. More specifically, approximately 2 -ft-long expanses of wicking material were tightly clamped top and bottom to the outside of the PVC. This measure also reduced the possibility that the entire wicking layer could be stripped from the PVC as it was inserted into the borehole or when casing was pulled.

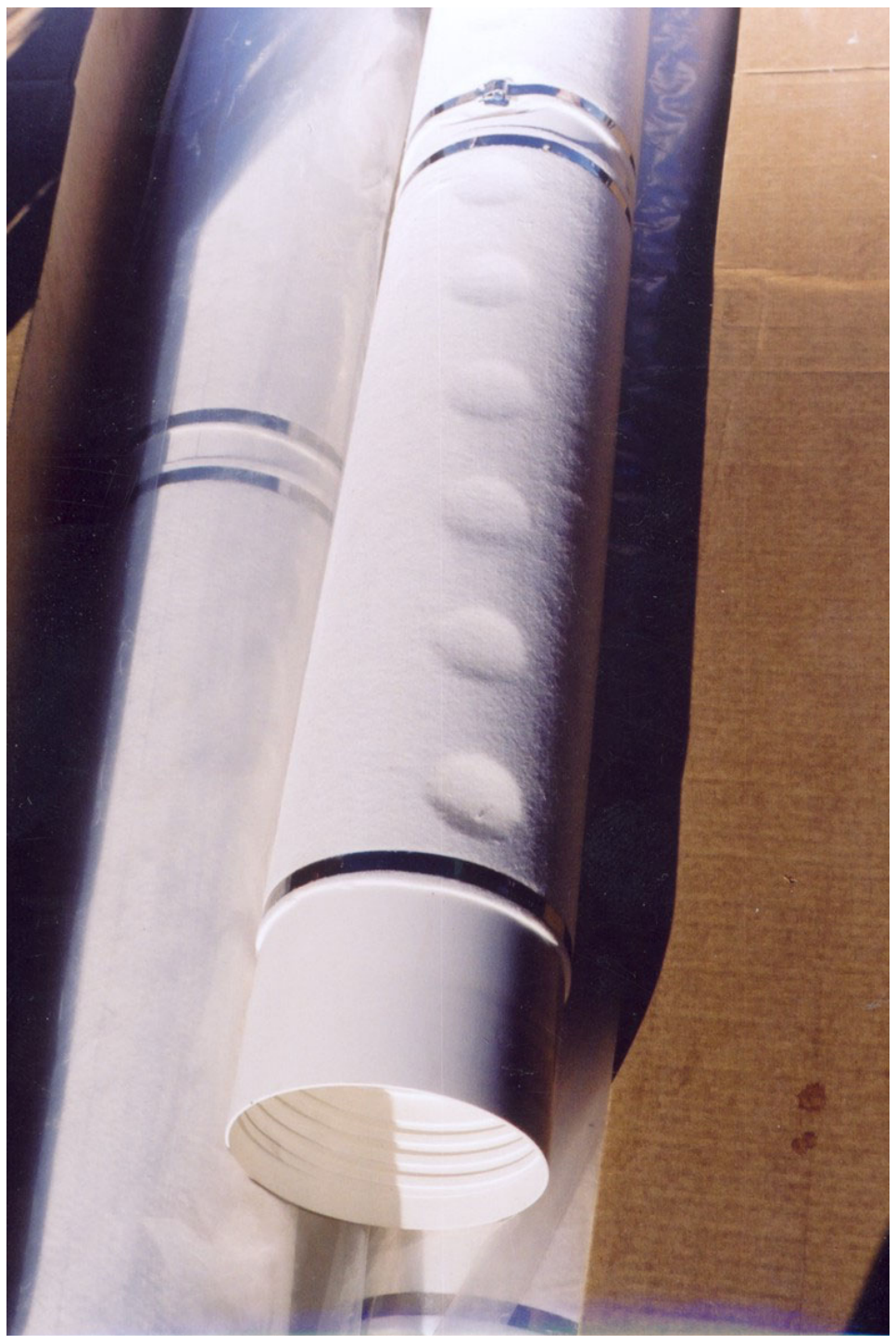

Figure 17. Perforated PVC shield (covered with wicking fabric) for liners in LAWS-03 
We began to retrieve the scalloped shield on 3 March 2002 using a two-step process: (1) running a steel washover pipe into the hole around the scalloped PVC to TD; and (2) pulling the PVC out, section-bysection, while the washover pipe kept the hole open. However, we had difficulty in advancing the washover pipe because of caving and lack of air circulation in this highly fractured basalt, thus limiting the length of its insertion to only $20 \mathrm{ft}$. So, with the washover pipe still in the hole, activity shifted to pulling the scalloped PVC, as described below.

- Only four 10 -ft joints of the scalloped PVC shield were initially recovered because it became unscrewed at a length of $40 \mathrm{ft}$. For some reason, screws had not been added to that connection.

- Recovery continued using an inflatable packer. Only $45 \mathrm{ft}$ more of the scalloped shield were recovered because the PVC broke off at approximately $85 \mathrm{ft}$ along the hole, the position of the previous collapse and blockage.

- As the cave-in prevented the advancement of the packer assembly into the remaining PVC, a tricone bit was advanced in an attempt to clear the blockage. However, this remedy failed because of lack of circulation.

We decided to complete the hole with perforated PVC (Figure 18) at the length of the blockage ( 85 $\mathrm{ft})$. At this position, LAWS-03 extends $75 \mathrm{ft}$ toward the pond and bottoms $40 \mathrm{ft}$ below the surface of the parking lot.

\section{Instrumentation of LAWS-03}

An 11-in. liner was no longer required for the new perforated PVC shield. It was decided that a 6-in. liner, previously prepared by FLUTe ${ }^{\mathrm{TM}}$ for these angled holes, would suffice. Since LAWS-03 ends above the $80-\mathrm{ft}$ water zone, it is intended to deal only with unsaturated conditions. As the useable portion of the hole is so short, the color-reactive liner was not deployed, but an absorbent liner was installed at the outset (Figure 19).

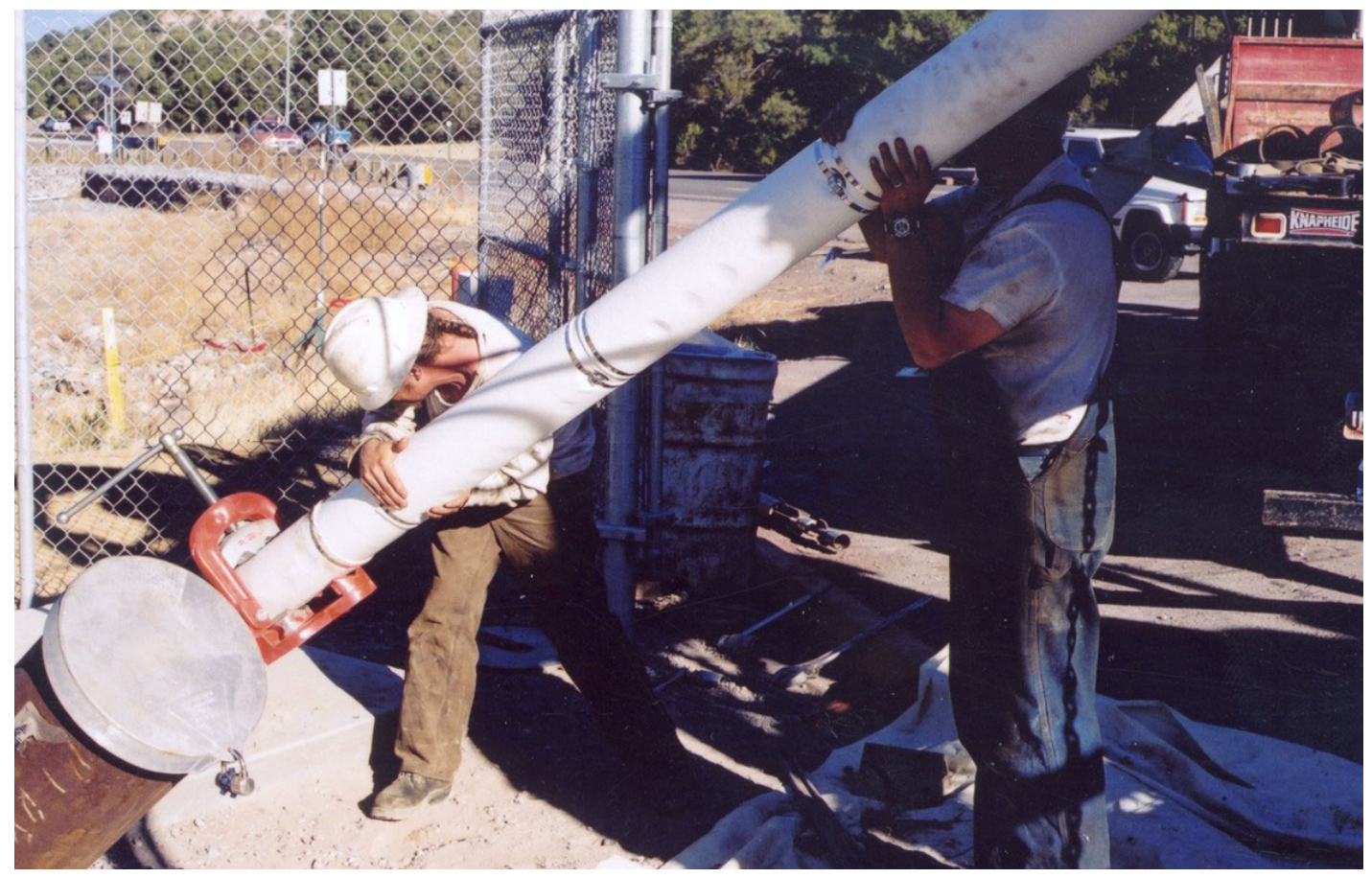

Figure 18. Constructing LAWS-03 with perforated PVC 


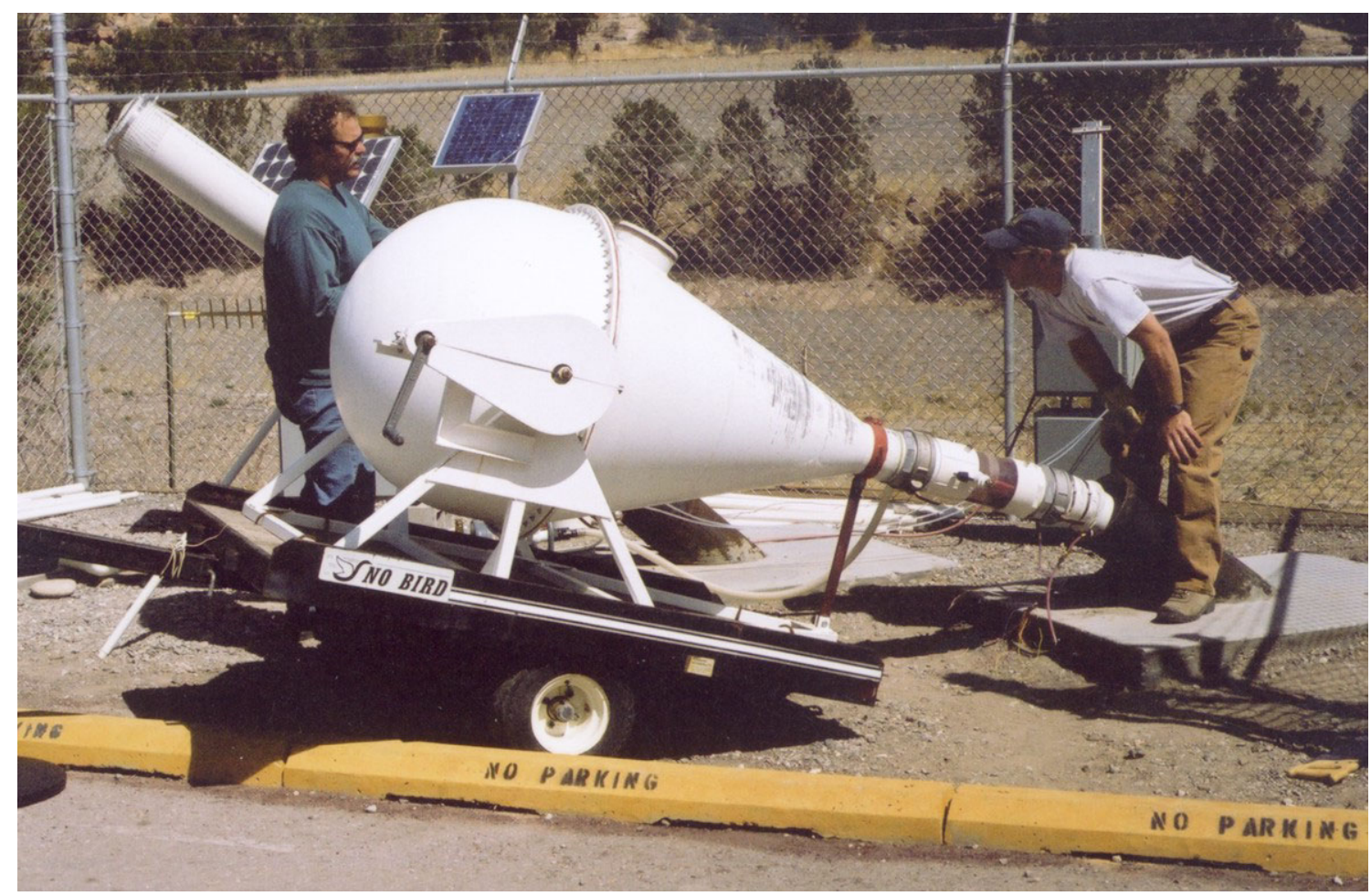

Figure 19. Installing absorbent liner in LAWS-03

A neutron-probe survey was made at LAWS-03 before the liner was installed. As the hole is not vertical, the probe had to be inserted by means of a 1-in. PVC ramrod.

\section{FINAL MONITORING SITE}

After providing for data collection, power, wellhead protection, and security, the site was completed in time for the 2002 summer monsoon season.

\section{Automatic Data Collection}

All subsurface observations made at the weir site are automatically recorded by a datalogger. These data include precipitation and atmospheric pressure at the site, water level collected by transducer in LAWS-01 and the electric-wire-pair moisture data associated with the liners in LAWS-02 and LAWS-03. Transducer measurements are made four times per day. All data are downloaded at least monthly and weekly during the summer monsoon season.

\section{Power Supply}

Power is provided for the various monitoring functions by two 12-volt deep-cycle marine batteries, three solar panels, and a small back-up battery for the datalogger. Inflation of liners is maintained by means of a Brailsford ${ }^{\mathrm{TM}}$ pump. The marine batteries provide the required power for the instrumentation and pump. The solar panels keep the batteries charged. A cold snap during the winter (2001/2002) caused the battery powering LAWS-02 to freeze and the liner deflated due to the power loss. The battery was replaced and its box well insulated to prevent freezing. 


\section{Wellhead Protection}

The site represents a unique source of data as well as a considerable investment. Thus, protective measures were taken to provide for both data integrity and equipment security. At each hole, surface casing was extended well above ground level for easy access. Tubes associated with the liners are gathered and organized with special fixtures at the wellhead (Appendix D). Wellhead protection is provided by steel casing extensions with locking covers (Figure 20). The casing extensions and concrete pads constructed around each wellhead provide sanitary seals. Conduits protect cables on the ground surface between the wellheads and the equipment shelters from both the elements and small animals with a propensity to gnaw.

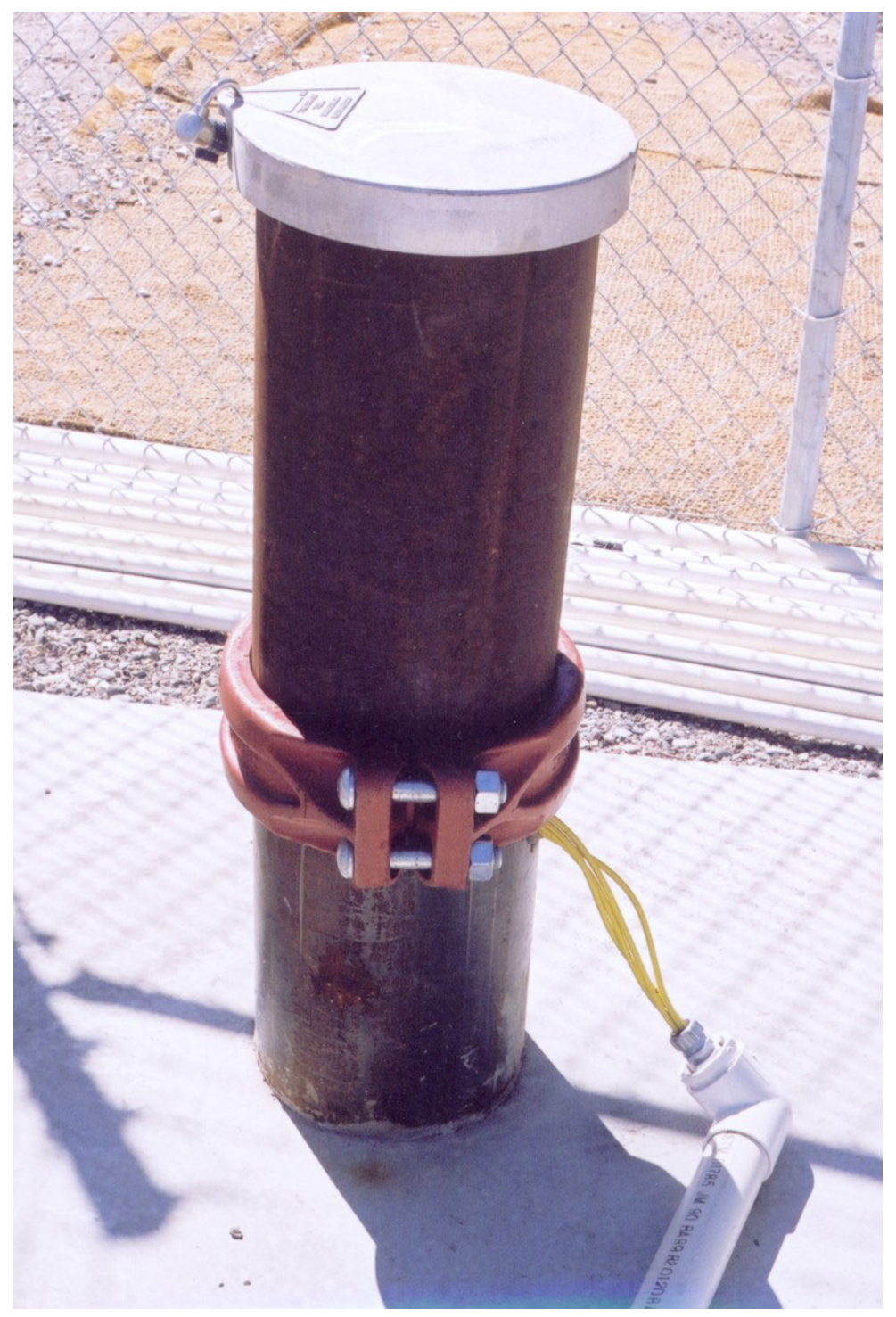

Figure 20. Wellhead protection for LAWS-01 


\section{Site Security/Access}

An 8-ft-high chainlink fence, erected around the holes, solar-panel poles and instrument shelters provides security (Figure 21). A pair of wide gates on the parking lot side permits access for liner installation/retrieval, or a workover rig, should that be necessary. Concrete curbs were placed between the gates and the parking lot to prevent vehicles from hitting the fence. The curbs are marked "No Parking" to ensure support vehicles have access to the gate for sampling or service.

\section{SURFACE-WATER MONITORING}

Surface-water data are essential for evaluating and modeling unsaturated flow and transport at the weir. Thus, some means of monitoring surface-water phenomena must be available. The depth of water ponded upstream of the weir is provided by a staff gage with a bubbler and Sutron 8210 data logger, installed by LANL in the summer of 2001 (Figure 22). Additionally, the amount of water lost to the subsurface during flow past the weir can be determined by comparing discharge data taken at stations above and below the structure. A gaging station (E042) already existed approximately $1 / 4$ mi upstream of the weir site, near R-9i (Shaull et al. 2001, 72609). However, to evaluate the impact of the weir, another station was needed downstream of the structure. Thus, in the summer of 2001, LANL installed another complete gaging station (E050) in Los Alamos Canyon below the weir (Figure 23). It consists of the same instrumentation as at the pond but has an $\mathrm{ISCO}^{\mathrm{TM}}$ automatic sampler as well.

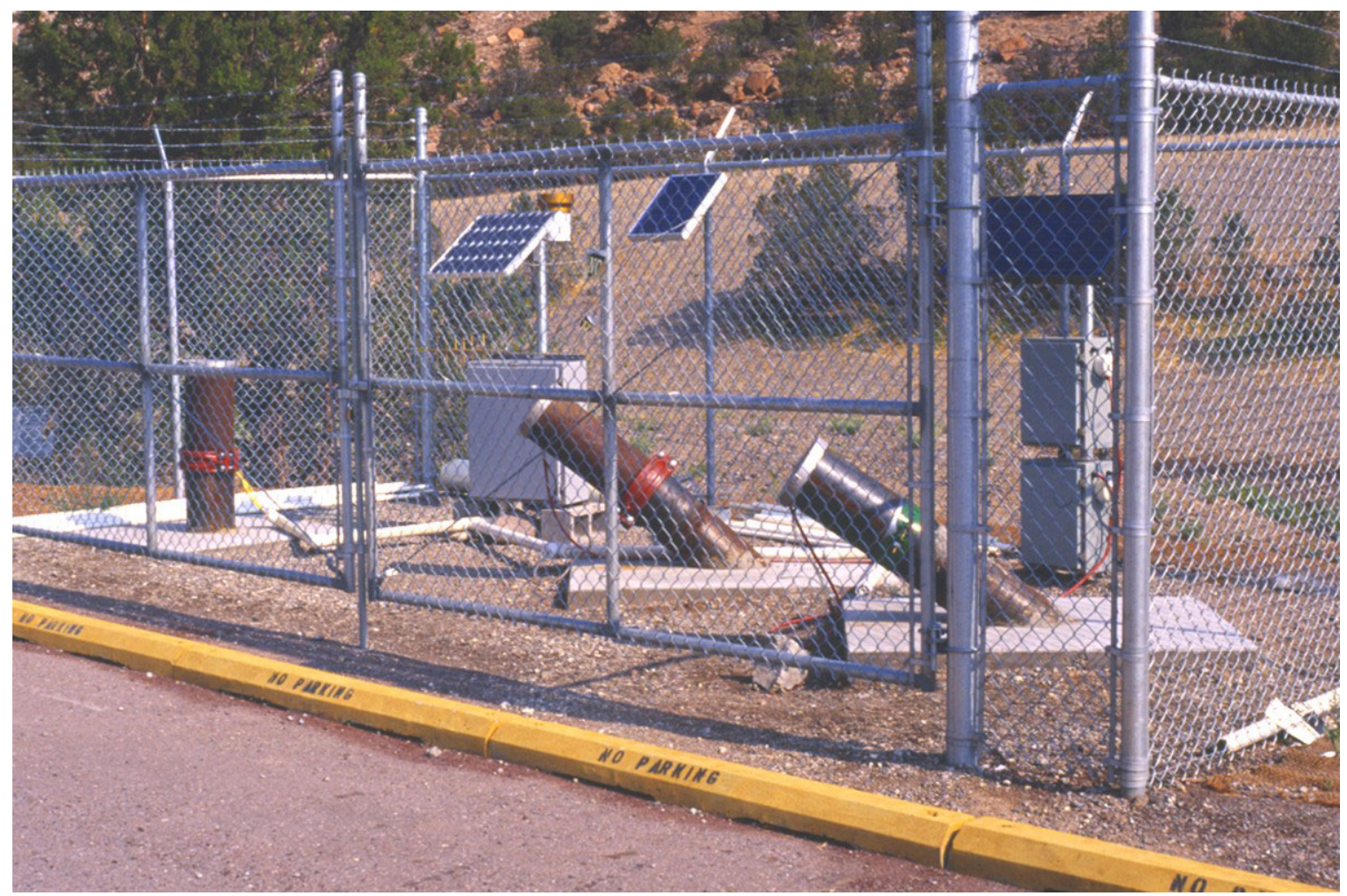

Figure 21. Completed monitoring station 


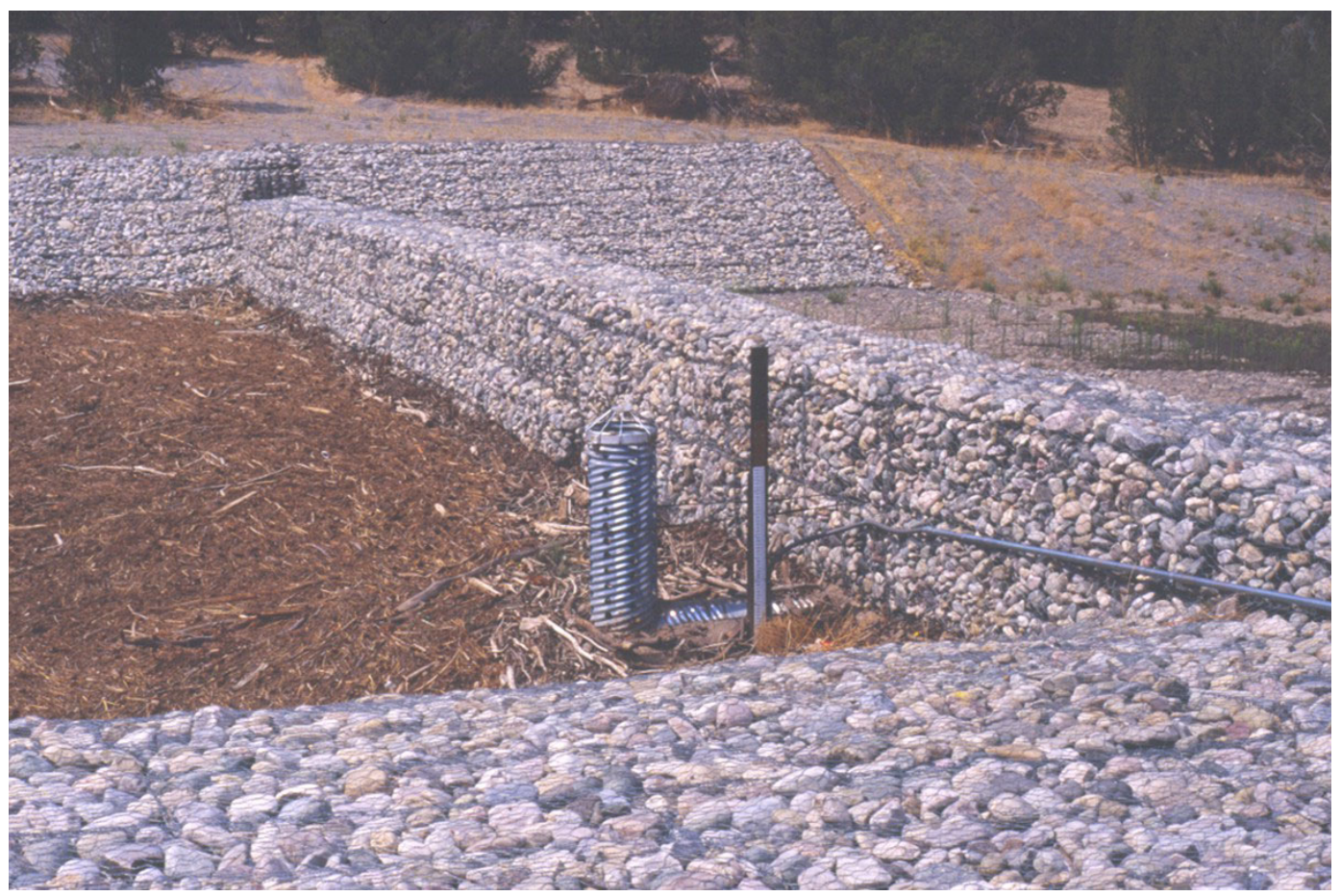

Figure 22. Pond gaging equipment upstream of the weir

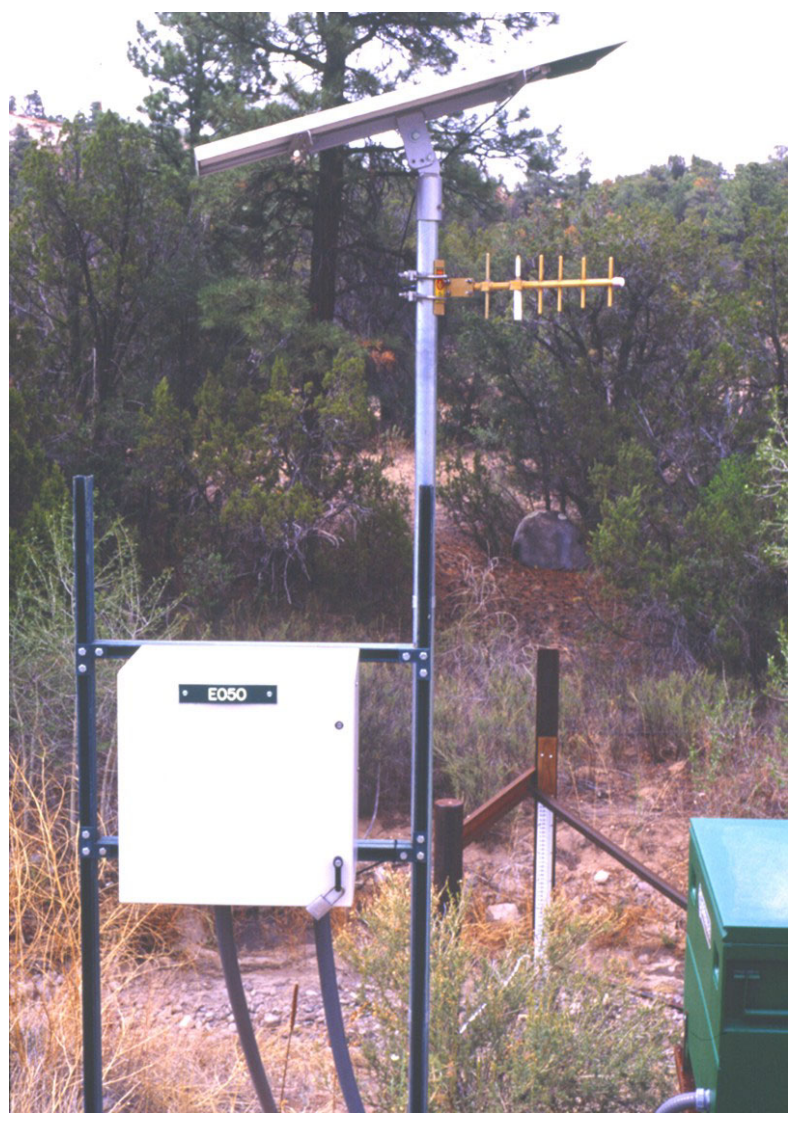

Figure 23. Stream gaging and sampling station downstream of the weir 


\section{SUMMARY AND CONCLUSIONS}

The monitoring site at the low-head weir in Los Alamos Canyon consists of one well (LAWS-01) and two instrumented angled boreholes (LAWS-02 and LAWS-03) in the Cerros del Rio basalt.

1. Holes in the highly fractured basalt were unstable and had to be drilled by casing-advance methods.

2. The basalt penetrated by the three boreholes seems to be quite permeable and connected to a nearby outcrop, based on the fact that the boreholes commonly blow or suck in response to atmospheric pressure.

3. Scalloped or perforated PVC shields had to be inserted before casing was pulled to keep the angled holes open while providing access to the borehole wall for the liners installed for monitoring and sampling.

4. LAWS-01 is vertical and was completed as a conventional monitoring well at a depth of $278 \mathrm{ft}$. It is outfitted with a Water FLUTe ${ }^{\mathrm{TM}}$ system for monitoring seasonal and perennial perched zones of saturation in four 10 -ft screened intervals.

5. LAWS-02 was drilled at an angle of $43^{\circ}$, is $156 \mathrm{ft}$ long, and extends to a depth of $106 \mathrm{ft}$ beneath the canyon floor. Insertion of a scalloped PVC shield for liners was successful.

6. LAWS-02 was initially instrumented with a color-reactive liner, equipped with electric-wire pairs to locate water-producing fractures. This was replaced with an absorbent liner with wire pairs in preparation for the summer monsoon season.

7. LAWS-03 was drilled at an angle of $34^{\circ}$ to a length of $137 \mathrm{ft}$ or a depth of $76 \mathrm{ft}$ bgs. Insertion of a scalloped PVC shield was not successful as openings rotated to the top and pieces of the highly fractured basalt repeatedly fell into it. An attempt to pull the scalloped PVC retrieved only $85 \mathrm{ft}$, and an obstruction at that depth could not be drilled out with equipment readily available. LAWS-03 was completed with perforated PVC covered with wicking material to a length of $85 \mathrm{ft}$. That translates to a depth of $40 \mathrm{ft}$ bgs.

8. LAWS-03 was instrumented with an absorbent liner with wire pairs at the outset, because of its shallow depth and the onset of the monsoon season.

9. Evidence that the 11-in. liner worked as intended through the scalloped PVC shield in LAWS-02 was obtained when the liner was pulled after a storm/ponding event in June 2002. Outlines of the scallops and smudges from the basalt were clearly visible on the liner, indicating that when inflated it had indeed extended out and come in contact with the borehole wall.

10. Soil-moisture data are an important part of the monitoring. The electric-wire pairs associated with the liners signal the arrival of a moisture front. Moisture data collected by neutron-probe surveys complement those obtained from the wire pairs. Such surveys shall be made at both LAWS-02 and LAWS-03, even when there are liners in the holes, by using a small-diameter PVC tremie pipe inside the liners.

\section{ACKNOWLEDGEMENTS}

This work was funded through emergency funds provided to the DOE and LANL to remediate damage and address demonstrated vulnerabilities associated with the Cerro Grande fire. This work has been conducted by Los Alamos National Laboratory through the Rehabilitation Project to address near- and long-term activities required for the Laboratory to fully recover from the Cerro Grande fire. This work was carried out as part of the Well-Head Protection Task (Task 0043) of the Rehabilitation Project.

Gilles Bussod (formerly employed by LANL) helped develop the idea and initial design for a monitoring site at the low-head weir in Los Alamos Canyon. Useful discussions with Bill Lowry (SEA) and Carl Keller (FLUTe ${ }^{\mathrm{TM}}, \mathrm{Inc}$ ) led to final instrumentation plans. Subsequently, numerous organizations and individuals 
contributed to the installation of the monitoring site. They performed various management, on-site, and reporting activities.

\section{Management}

We thank Steve Mee, CGRP manager, for funding the installation. We are also grateful to Diana Hollis (then with ER), University Technical Representative (UTR), for management support throughout the installation of the site in 2001. Charlie Nylander (then with ESH-18), co-PI, obtained additional funding and services (especially for surface-water gages) through ESH-18. Charlie Nylander replaced Diana Hollis as UTR in 2002 and together with Steve Rae (then ESH-18 Group Leader) managed fire monies for the completion of LAWS-03, site maintenance, and subsequent data collection in 2002. As ESH-18 had no means of retaining drilling and consultant services, Kathryn De Lima (BUS-8) administered funding for the weir project work through existing ER contracts. Kent Rich (ER/RRES) tracked allocations and expenditures. Donna Martinez (then with ER) expedited work orders as needed during the main installation phase.

\section{On-Site Activities}

Drilling was done by personnel of SBDC and DDI. James McDonald (then with SEA) shared Field Team Leader duties with Dennis Newell. Dave Hill (Washington Group) was Site Safety Officer. Rene Evans (Washington Group) and Roy Bohn (then with ER) managed site-generated waste. Mike Klahn (then with Schlumberger) and Bob Hull (LATA) provided general oversight of drilling activities. Dave Wykoff and Keith Tucker, Alan Shumaker (SEA) installed flexible liners. Discussions regarding shield and liner design, deployment, and function with Carl Keller, Paul Werenko and John Collins (FLUTe ${ }^{T M}$, Inc.) were especially helpful. David Schaull (then with ESH-18) provided and operates the surface-water equipment above, at, and below the weir.

\section{Reporting}

Christy Flaming (IM-1/RRES) produced the cover illustration. Phil Stauffer (EES-6) provided the photo used for Figure 3. Alan Shumaker provided the as-built and well-head diagrams in Appendices B, C, and D. Bill Kopp (ESH-19) provided the topographic map for Figure 4. Anthony Garcia (EES-6) created Figures 2 and 6 and redrew Figure 10 from an illustration provided by $\mathrm{FLUTe}^{\mathrm{TM}}$, Inc. He and Randi Moore (IM-1/RRES) finalized all figures for the report. Meena Sachdeva (IM-1/RRES) edited the document, and Pam Maestas (Neptune) and Randi Moore were compositors. Although formal peer review of this document was not required, comments solicited from Dave Vaniman (EES-6), Mike Klahn (Neptune), and Charlie Nylander (RRES) are gratefully acknowledged.

Finally, we especially wish to thank the area car-poolers for their cooperation in making other arrangements while the "Y" parking lot was closed during drilling of the boreholes in 2001.

\section{REFERENCES}

Bouwer, H., and R.C. Rice, 1976. "A Slug Test for Determining Hydraulic Conductivity of Unconfined Aquifers with Completely or Partially Penetrating Wells," in Water Resources Research 12, pp. 423-428. (Bouwer and Rice 1976, 64056) 
Broxton, D., D. Vaniman, W. Stone, S. McLin, M. Everett, and A. Crowder, 2001. "Characterization Well R-9i Completion Report," Los Alamos National Laboratory Report LA-13821-MS, Los Alamos, New Mexico. (Broxton et al. 2001, 71251)

Broxton, D., R. Gilkeson, P. Longmire, J. Marin, R. Warren, D. Vaniman, A. Crowder, B. D. Newman, B. Lowry, D. Rogers, W. Stone, S. McLin, G. WoldeGabriel, D. Daymon, and D. Wykoff, May 2001. "Characterization Well R-9 Completion Report," Los Alamos National Laboratory Report LA-13742-MS, Los Alamos, New Mexico. (Broxton et al. 2001, 71250)

Gallaher, B., K. I. Mullen, and M. Alexander, 2001. "Runoff Following the Cerro Grande Fire," in New Mexico Bureau of Mines and Mineral Resources, New Mexico Decision-Makers Field Guide No. 1, pp. 48-49. (Gallaher et al. 2001, 72662)

Griggs, R.L., 1964. Geology and Ground-Water Resources of the Los Alamos Area, New Mexico: U.S. Geological Survey, Water-Supply Paper 1753, Washington, D.C. (Griggs 1964, 65649)

Joseph, K., 2001. "The Cerro Grande Fire, Santa Fe National Forest, May 2000," in New Mexico Bureau of Mines and Mineral Resources, New Mexico Decision-Makers Field Guide No. 1, pp. 34-36. (Joseph 2001, 72662)

LANL (Los Alamos National Laboratory), 1998. "Hydrogeologic Workplan," rev. 01, Los Alamos National Laboratory Report, Los Alamos, New Mexico. (LANL 1998, 59599)

Shaull, D.A., M.R. Alexander, R.P. Reynolds, R.P. Romero, E.T. Riebsomer, and C.T. McLean, 2001. "Surface Water Data at Los Alamos National Laboratory - 2000 Water Year," Los Alamos National Laboratory Report, Los Alamos, New Mexico. (Shaull et al. 2001, 72609)

Stone, W.J., 2002. "Use of Flexible Liners in Unstable Angled Boreholes at LANL" (Poster Abstract), Proceedings of the New Mexico Geological Society Annual Spring Meeting, Socorro, New Mexico, p. 50. (Stone 2002, 72663) 


\section{GLOSSARY}

As some terms used in this report may not be familiar to readers, those most likely requiring clarification are defined below.

Adsorbed. Taken up by adsorption; the accumulation of gases, liquids or solutes on the surface of a solid or liquid.

Air-rotary drilling. A drilling method in which the bit is cooled and cuttings are circulated out of the hole by air under pressure.

Alluvium. Sedimentary deposit formed by running water and consisting of any mixture of gravel, sand, silt or clay.

Basalt. Dark colored extrusive igneous rock formed by cooling of silica-poor lava.

Bentonite. A swelling clay placed in the annulus between a production casing and the borehole wall to serve as an impermeable seal between screens.

Carbonate. Calcium carbonate (the mineral calcite); when formed in fractures appears as coatings on drill cuttings

Casing-advance drilling. A drilling method in which the bit under-reams steel casing so it can follow the bit down the hole as it is being drilled; used to prevent caving and allow installation of production casing inside the drill casing as it is retrieved.

Circulation. Movement of air in and out of the borehole while drilling by rotary methods to bring cuttings to the surface.

Cobble. Gravel clast, 64 to $256 \mathrm{~mm}$ in size.

Color-reactive liner. Liner used to map moisture-producing zones in a borehole; consists of red crepe paper beneath a thin cotton covering; when liner comes in contact with water, red color bleeds onto the cotton.

Dacitic. Characterized by dacite, a dark-colored extrusive igneous rock formed by cooling of lava containing more silica than basalt.

Datalogger. A device that electronically stores instrument output.

Eversion. Normal means of deploying a flexible liner; analogous to returning a very long sock to its original shape after its toe has been pulled to the opening by pushing the toe back down through the sock using air or water.

Filter pack. Sand or gravel placed in the annulus between the screen and borehole wall to prevent rock particles from entering a well.

Flexible liner. A sleeve that is everted by air or water into a borehole or well for the purpose of monitoring hydraulic conditions or sampling water from saturated or unsaturated zones.

Gabion. A structure consisting of a strong wire mesh filled with river boulders; used for controlling erosion and surface-water flow. 
Grout. A mixture of cement and water plus various additives (such as bentonite), of a consistency such that it can be forced through a pipe; used in annular seals to isolate screens, in sanitary seals to prevent contamination from surface runoff, or in plugging holes when they are abandoned.

Head. Position of the water level in a well or surface-water body relative to a specified datum, usually mean sea level; water level as elevation.

Hydrogeology. Relationship of a hydrologic system to the geologic framework within which it operates.

Impermeable. Said of a geologic material lacking the ability to transmit fluids, especially water.

Lithics. Fragments of rocks (as opposed to minerals) occurring in rocks or recovered in drill cuttings.

Low head. Low water-level elevation; implies minimal depth of water.

Massive. Nonvesicular.

Micron. Unit of length equal to one millionth of a meter.

Old alluvium. Informal geologic unit name used by Griggs $(1964,65649)$ for remnants of high-level alluvial deposits in the east-central Los Alamos area.

Olivine. Green colored silicate mineral commonly occurring in basalt.

Perched water. Water occurring in a saturated zone lying above the regional water table; water separated from regional saturation by the presence of an impermeable layer upon which it is perched.

Permeable. Said of a geologic material having the ability to transmit fluid, especially water.

Phenocrysts. Larger crystals set in finer matrix in porphyritic igneous rocks.

Porphyritic. Texture of igneous rocks containing more than one crystal size.

Recovery. The amount of cuttings returned to the surface in rotary drilling.

Regional water table. Top of the regionally extensive zone of saturation.

Runoff. Movement of water over the land surface; includes that in channels and on slopes.

Screen. Portion of production casing that has openings to permit water but not geologic media to enter a well.

Smectitic. Containing the swelling clay mineral smectite.

Tephra. Volcanic ash.

Transducer. Instrument for determining water level in wells or surface-water bodies; actually measures height of overlying water column; reference to a datum gives water level as elevation or depth.

Transmissive. Water-producing, permeable.

Tremie pipe. Small-diameter tube used to facilitate the introduction of instruments into a borehole or well.

Vesicular. Containing vesicles or holes; common texture of extrusive igneous rocks such as basalt; formed by the rapid cooling of thin bubble walls when gas escapes from a lava. 
Washout. Interval in a borehole where diameter is larger than the drill bit because of caving of fractured rock or sloughing of unconsolidated sediment.

Water table. Top of a saturated zone.

Water quality. Chemical characteristics of a water; the identity and concentration of dissolved constituents in a water, including major ions, metals, organics and radionuclides.

Weir. A structure placed across a stream to regulate flow.

Wicking fabric. Cloth having small pores that is used to capture water moving in response to capillary forces.

Workover rig. Small rig with a mast and a winch used to bail a well, install instruments, pull pumps, etc. 



\section{Appendix A}

\section{Detailed Field Logs for the Well and Angled Boreholes}

\section{Contents}

A-1. Detailed log for LAWS-01

A-2. Detailed log for LAWS-02

A-3. Detailed log for LAWS-03

\section{Explanation}

$<$ less than

$<\quad$ much less than

Dark gray (N3) color classification based on a standard Rock-Color Chart

\section{Notes}

See list at front of document for abbreviations used.

See Glossary for definitions of unfamiliar terms. 



\section{A-1. Detailed log for LAWS-01}

Borehole ID: LAWS-01

Drilling Company: Dynatec

Driller: Larry Thoren
Location: TA-72, LA Weir

Start Date: $\mathbf{4 4 0 1}$

End Date: 4.6 .01

Drilling Equipment/Method: SCHRAMM T685W Rotadrill/Air Rotary Casing Adavance

Sampling Equipment/Method: Cyclone/Chips

Geologist: Dennis Newell, Science and Engineering Associates

\section{Bearing/lnclination: $\mathrm{NA} / 90$ degrees}

Northing: 1770853.959

Easting: 1649524.509

Elevation: $6304.9 \mathrm{ft}$

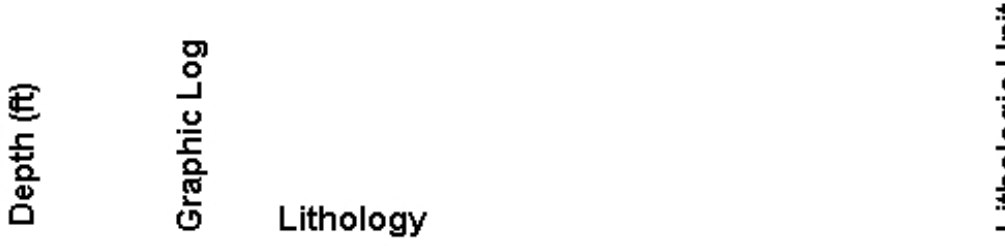

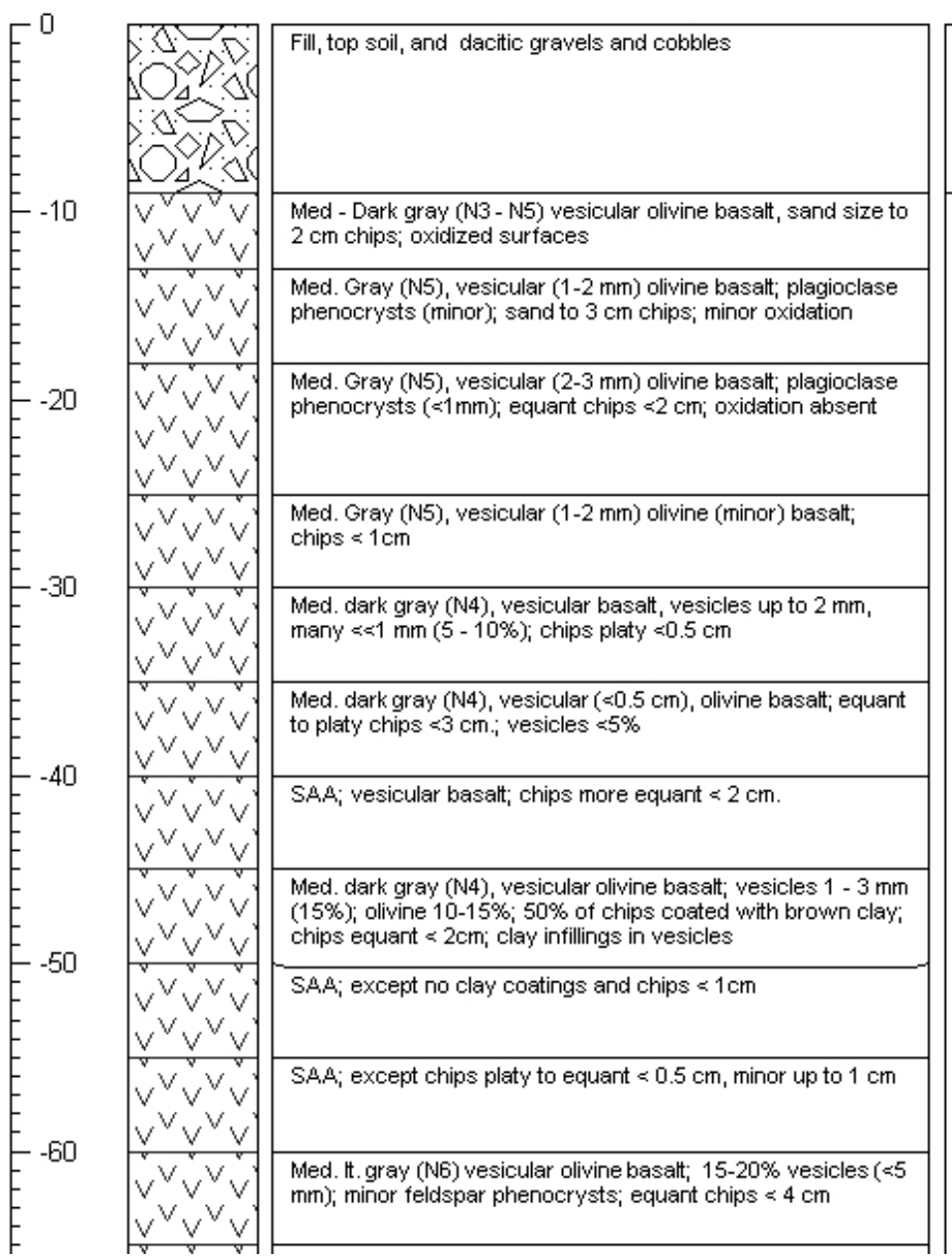

는
능
응
폽

Notes

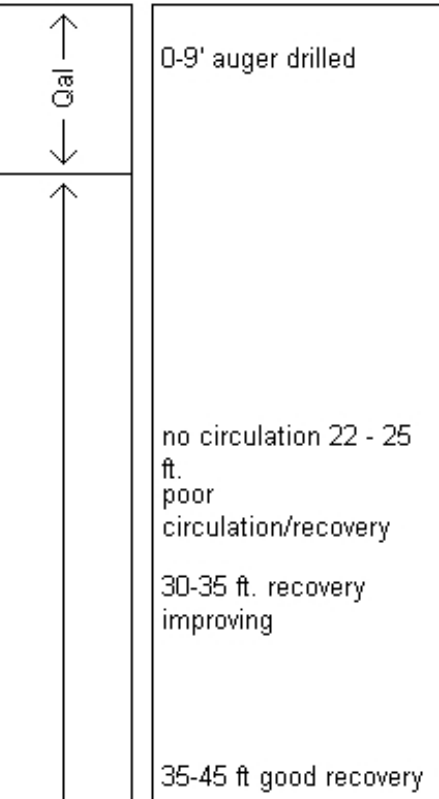

$35-45 \mathrm{ft}$ good recovery
일

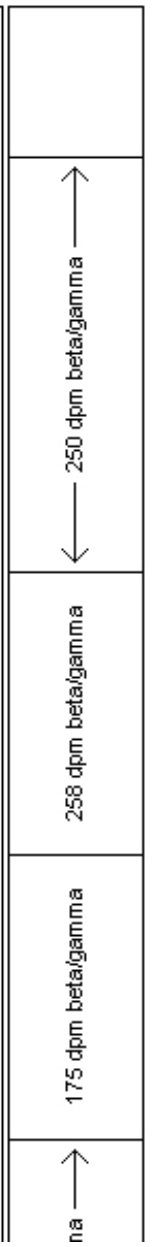




\begin{tabular}{|c|c|c|}
\hline & $\left|\begin{array}{l}v^{v} \vee v \\
v^{v} \vee v\end{array}\right|$ & $\begin{array}{l}\text { Med. It. gray to Med. gray (N6 - N5); vesicular olivine (rare) } \\
\text { basalt; } 15-20 \% \text { vesicles ( }<3 \text { mm); clay absent; minor feldspar } \\
\text { pheno's (plagioclase); chips platy }(\leqslant 0.5 \mathrm{~cm}) \text { and equant }(<2 \mathrm{~cm})\end{array}$ \\
\hline 80 & & SAA; very poor recovery \\
\hline & & SAA \\
\hline-80 & & SAA; with oxidation and clay coatings \\
\hline & & SAA \\
\hline-90 & & SAA \\
\hline & $\begin{array}{l}\underline{x} \bar{x} \\
x \bar{x} \\
x=\end{array}$ & $\begin{array}{l}\text { Med. It gray (N6) massive olivine basalt; } 40-50 \% \text { clods of } \\
\text { v.fine grained glass and black lithics (tephra); minor oxidatized } \\
\text { surfaces }\end{array}$ \\
\hline 100 & & Med. It. gray (N6), massive olivine basalt \\
\hline & $\frac{\bar{v}}{\bar{V}}=$ & $\begin{array}{l}\text { Med. gray (N5), vesicular olivine basalt; v.fine grained matrix } \\
\text { (glass + black lithics) plus tephra }\end{array}$ \\
\hline-110 & & no recovery \\
\hline & & same as $105-110$ ' interval \\
\hline & & $\begin{array}{l}\text { SA,; vesicular olivine basalt; clay clods, it brown, smectitic 1-2 } \\
\text { cm mixed with v. fine grained matrix (tephra); mattix } \sim 50 \%\end{array}$ \\
\hline & & $\begin{array}{l}\text { SA,A; basalt, with "soupy" tephra matrix; basalt chips have it } \\
\text { brown ( } 5 Y R \text { ( 5/6) smectitic coatings }\end{array}$ \\
\hline & & $\begin{array}{l}\text { SA, basalt with } 50 \% \text { clay clods (It brown } 5 Y R 5 / 6 \text {, smectitic, } \\
1-2 \mathrm{~cm} \text { ) }\end{array}$ \\
\hline & & $\begin{array}{l}80 \% \text { clay (It brown } 5 Y R 5.6 \text {, smectitic) with } 20 \% \text { massive } \\
\text { basalt; coarse sand-size chips, some up to } 2.5 \mathrm{~cm}\end{array}$ \\
\hline & & $\begin{array}{l}\text { Med. dark gray (N4) massive olivine basalt (chips platy to } \\
\text { subequant } \angle 2 \mathrm{~cm} \text { ); clay clods } ~ 50 \%\end{array}$ \\
\hline & & Grayish black ( $N 2$ ) massive basalt; chips equant $<1.5 \mathrm{~cm}$ \\
\hline & $\begin{array}{l}\underline{x} \bar{y} \\
\underline{x} \bar{y}\end{array}$ & $\begin{array}{l}\text { SA,A; massive basalt plus } \sim 30 \% \text { tephra matrix (v. fine grained } \\
\text { glass + black lithics); clay chips common }\end{array}$ \\
\hline & & $\begin{array}{l}\text { Grayish black (N2) vesicular basalt; oxidized surfaces } \\
\text { (goethitehematite?), brown clay clods common. }\end{array}$ \\
\hline & & $\begin{array}{l}\text { SAA; basalt with plagioclase pheno's ( } 3 \% \text { ); clay clods less } \\
\text { common; chips irregular shaped up to } 5 \mathrm{~cm}\end{array}$ \\
\hline & & SAA \\
\hline & & SAA; prominent vesicle fillings (clay andior carbonate?) \\
\hline & 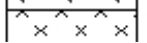 & ayish black (N2) mass \\
\hline
\end{tabular}

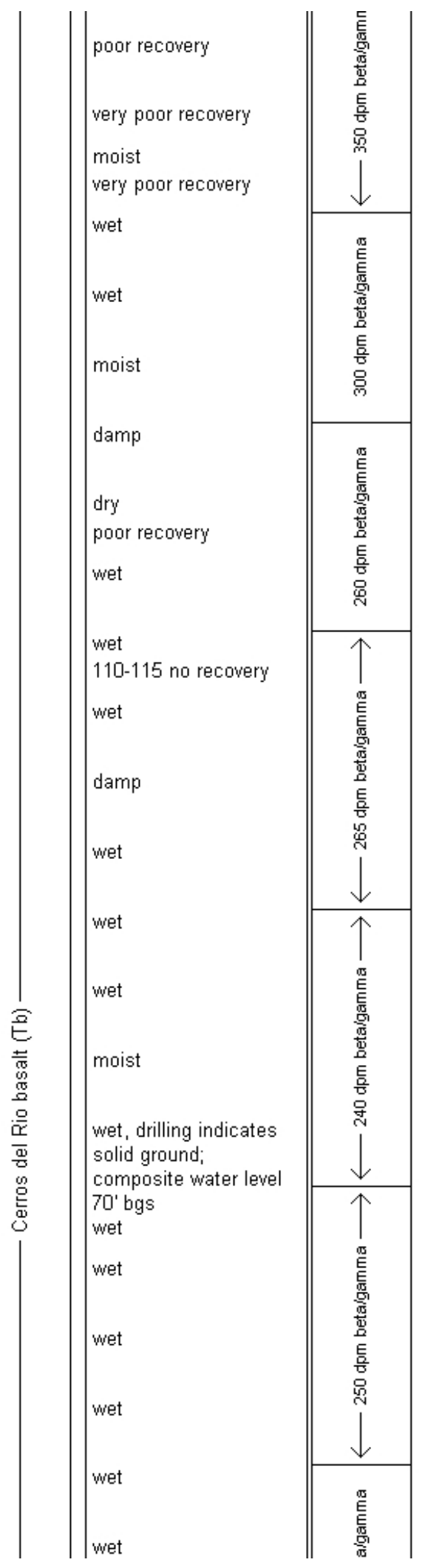




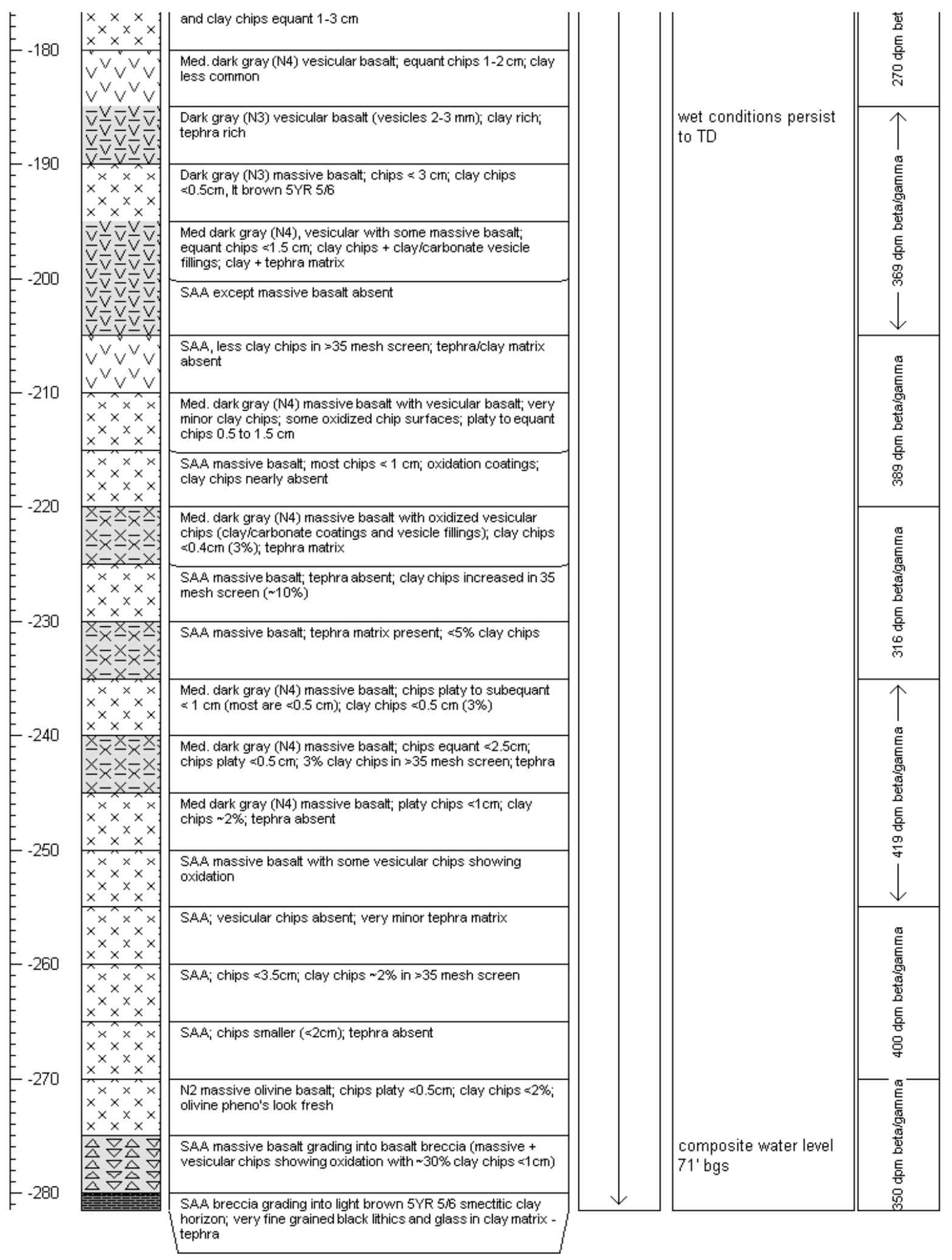




\section{A-2. Detailed log for LAWS-02}

Borehole ID: LAWS-02

Drilling Company: Dynatec

Driller: Larry Thoren
Location: TA-72, LA Weir

Start Date: $4 / 22 / 01$

End Date: $4 / 25 / 01$

Drilling Equipment/Method: SCHRAMM T685W Rotadrill/Air-rotary-casing-advance

Sampling Equipment/Method: Cyclone/chips

Geologist: Dennis Newell, Science and Engineering Associates

Bearing/lnclination: $\mathrm{N} 40 \mathrm{E} / \sim 33$ degrees
Easting: 1649536.913

Elevation: $6304.9 \mathrm{ft}$
Lithology

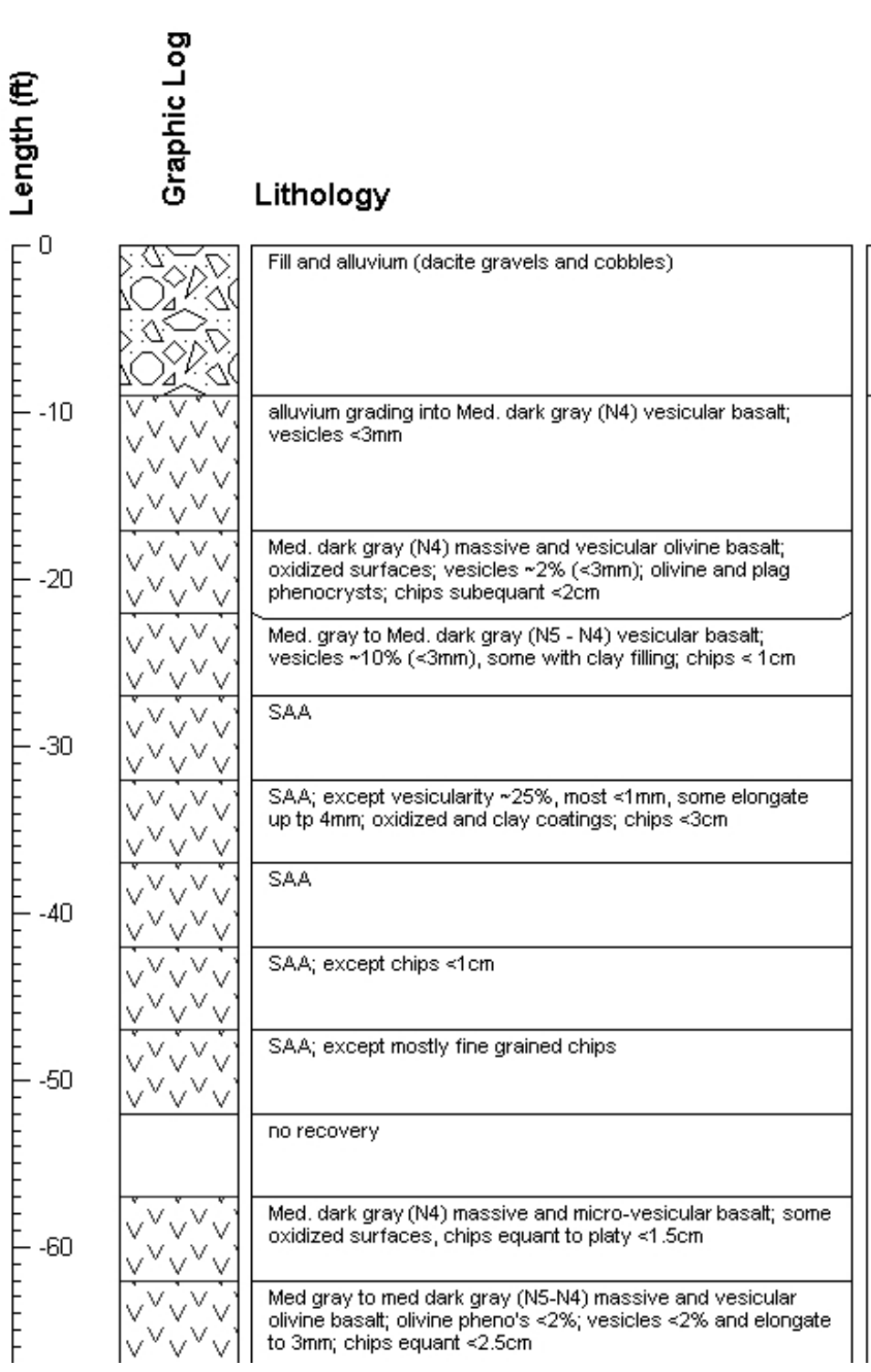

는
응
응
돈

Notes

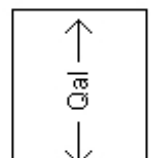

$4 / 22 / 01$

48303010700

Run 2: 0820

lost circulation; 23-27

very poor recovery

circulation restored

good circulation: 1020

poor recovery: 1310

52-57 no recovery:

1450

circulation returned:

1510

good recovery 


\begin{tabular}{|c|c|c|}
\hline-70 & $\sqrt{v}$ & $\begin{array}{l}\text { Med. - Med. dark gray (N5 - N4) vesicular basalt; vesicles } \\
\sim 10 \% \quad(\approx 2 \mathrm{~mm} \text {, some elongate); oxidization and clay coatings } \\
\text { common; chips equant to subequant }<1.5 \mathrm{~cm}\end{array}$ \\
\hline-80 & & $\begin{array}{l}\text { Med. - med dark gray (N5 - N4) vesicular olivine basalt; olivine } \\
2-5 \% \text {; vesicles } 15 \%(\approx 2 \mathrm{~mm}) \text {; minor oxidation and clay }\end{array}$ \\
\hline & & $\begin{array}{l}\text { Med. - med dark gray (N5 - N4) vesicular olivine basalt, some } \\
\text { massive; olivine }<5 \% \text {; vesicles } 5-10 \% \text { (most }<2 \mathrm{~mm} \text {, some } \\
\text { elongate) }\end{array}$ \\
\hline 90 & & SAA \\
\hline & & $\begin{array}{l}\text { Med gray to med It gray (N6 - N7) vesicular olivine basalt; } \\
\text { olivine }<5 \% \text {; vesicles }<2 \mathrm{~mm}\end{array}$ \\
\hline-100 & $x^{x}$ & $\begin{array}{l}\text { Med it gray (N6) massive olivine basalt; fine grained matrix } \\
\text { (tephra??) }\end{array}$ \\
\hline & & $\begin{array}{l}\text { Med gray (N5) vesicular olivine basalt; olivine }<5 \% ;<5 \% \text { plag } \\
\text { phenos; elongated vesicles to } 5 \mathrm{~mm} \text {; very thin coating of } \\
\text { orangish clay }\end{array}$ \\
\hline 110 & & $\begin{array}{l}\text { Lt. gray (N7) vesicular basalt; highy vesicular up to } 4 \mathrm{~mm} \text {; } \\
\text { oxidizediclay coatings; coarse chips }\end{array}$ \\
\hline & $x^{x} x^{x} x$ & $\begin{array}{l}\text { med to It gray (N6 - N7) massive olivine basalt; olivine } \sim 10 \% \text {; } \\
\text { peach colored oxidizediclay coating; fine grained chips }\end{array}$ \\
\hline-120 & $x^{x}+x$ & $\begin{array}{l}\text { med gray (N5) massive to very finely vesiculated basalt; } \\
\text { orange clay } \sim 20 \% \text {; medium grained where massive }\end{array}$ \\
\hline & & $\begin{array}{l}\text { med. gray (N5) vesicular olivine basalt; olivine to } 5 \% \text {; vesicles } \\
\text { to } 5 \mathrm{~mm}(15 \%) \text {; other phenocrysts } \_5 \% \text {; orange clay }\end{array}$ \\
\hline-130 & & $\begin{array}{l}\text { med. gray (N5) vesicular basalt; vesicles }<2 \mathrm{~mm} \text {; medium } \\
\text { grained; } 5 \% \text { orange clay }\end{array}$ \\
\hline & & $\begin{array}{l}\text { clay with vesicular basalt; } 50 \% \text { orange clay clods; vesicles } \\
<2 \mathrm{~mm} \text {, some up to } 8 \mathrm{~mm} \text {, clay filled. }\end{array}$ \\
\hline--1 & & $\begin{array}{l}\text { med to It gray (N6-N7) vesicular basalt; very large elongate } \\
\text { vesicles to } 12 \mathrm{~mm} \text {; coarse chips; clay coating and } 30 \% \text { orange } \\
\text { clay chips }\end{array}$ \\
\hline & $\bar{v}$ & $\begin{array}{l}\text { med It gray (N6) vesicular and massive basalt mixed with } 30 \% \\
\text { orange clay; small vesicles }<2 \mathrm{~mm} \text {; thin clay coating on basalt } \\
\text { chips }\end{array}$ \\
\hline & & SAA; vesicles slightly larger ( $4 \mathrm{~mm}$ ) \\
\hline & & SAA; vesicles larger, to $8 \mathrm{~mm}$ and elongated \\
\hline
\end{tabular}

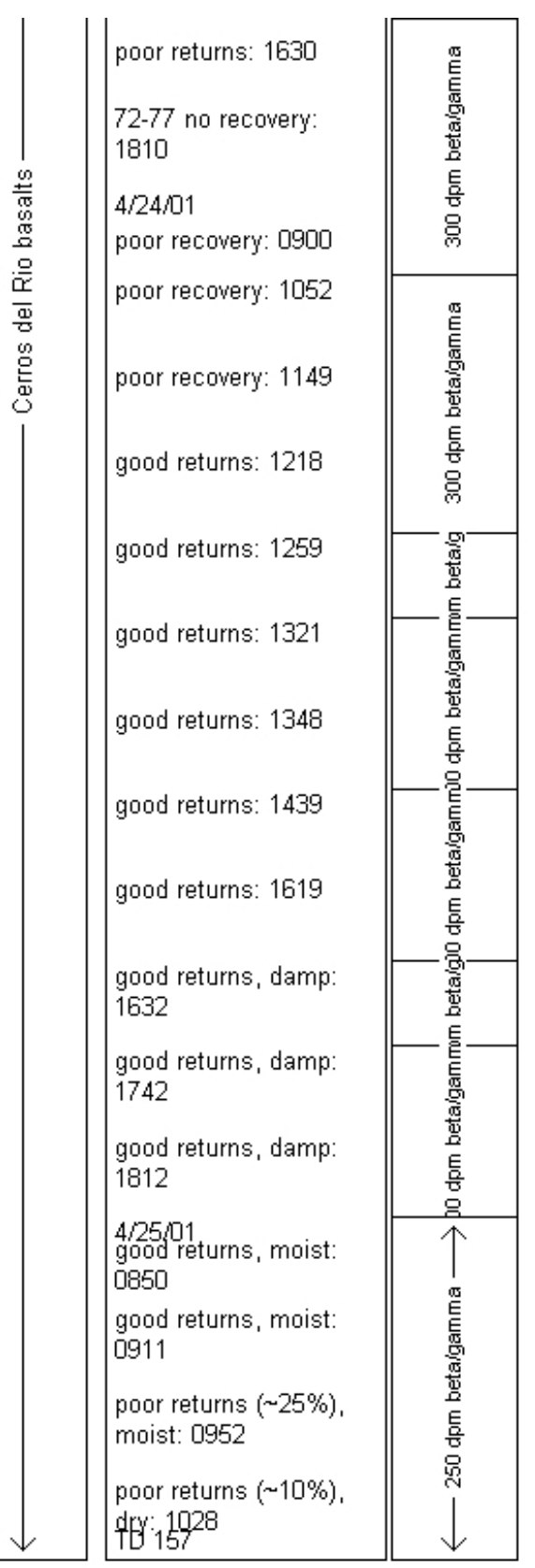




\section{A-3. Detailed log for LAWS-03}

Borehole ID: LAWS-03

Drilling Company: Dynatec

Driller: Larry Thoren
Location: TA-72, LA Weir

Start Date: $4 / 27 / 01$

End Date: $4 / 28 / 01$

Drilling Equipment/Method: SCHRAMM T685W Rotadrill/Air-rotary-casing-advance

Sampling Equipment/Method: Cyclone/chips

Geologist: Dennis Newell, Science and Engineering Associates

Bearingilnclination: $\mathrm{N} 40 \mathrm{E} / \sim 34$ degrees

Northing: 1770848.8

Easting: 1649542.9

Lithology

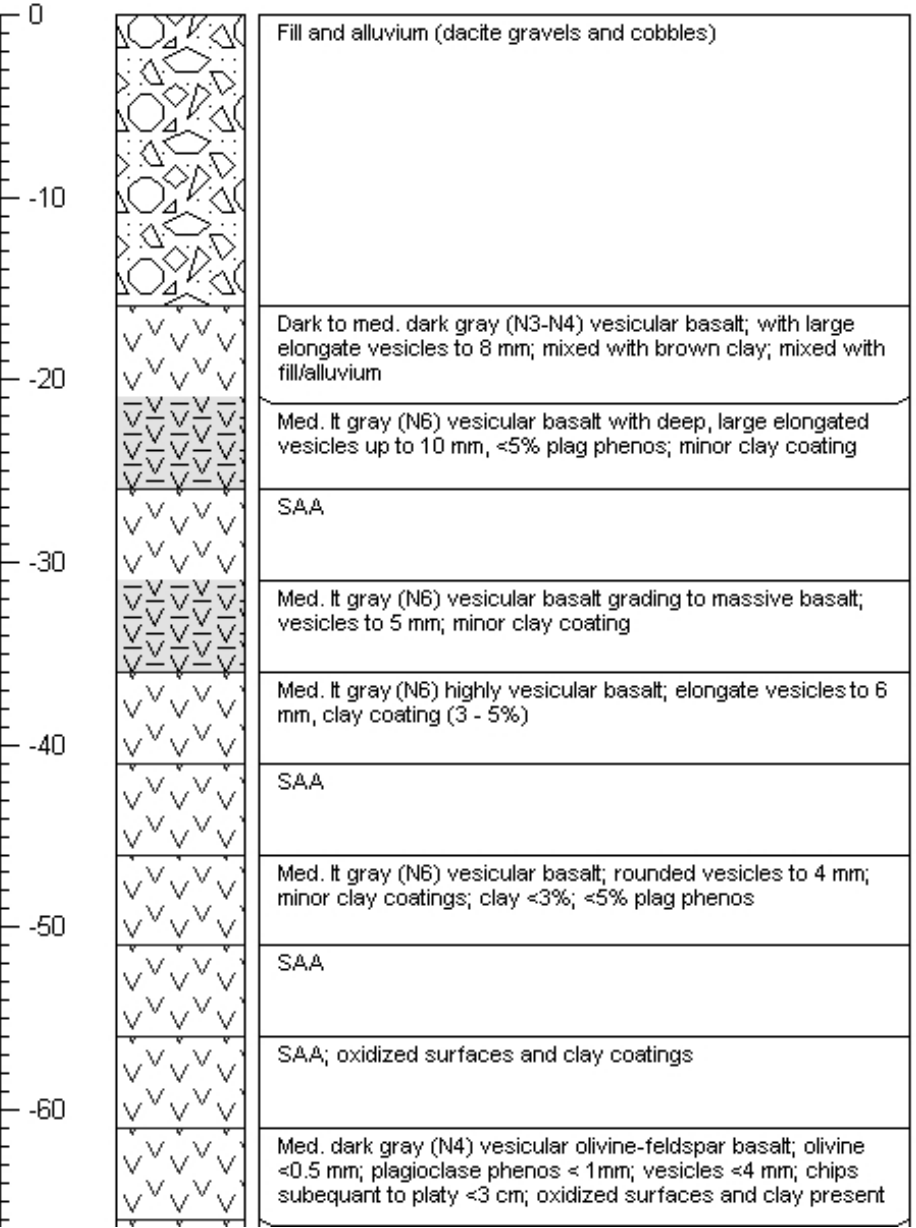

Elevation: $6304.9 \mathrm{ft}$

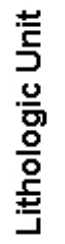

Notes

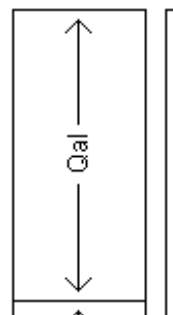

4. $-27-011408$
Poor returns

good recovery: 1507

good returns; 1600

good returns: 1624

good returns: 1653

outstanding returns

1711

good returns;

competent formation;

1749

good returns; 1804

4-28-010700

OK returns 0740

good returns: 0845

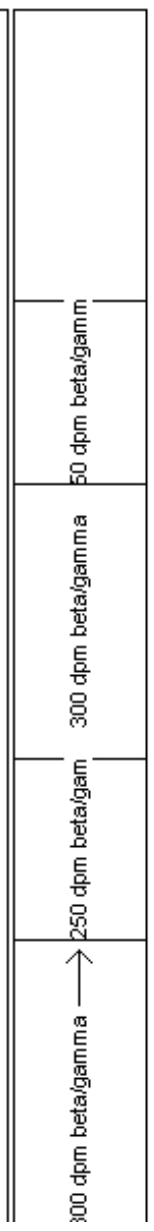




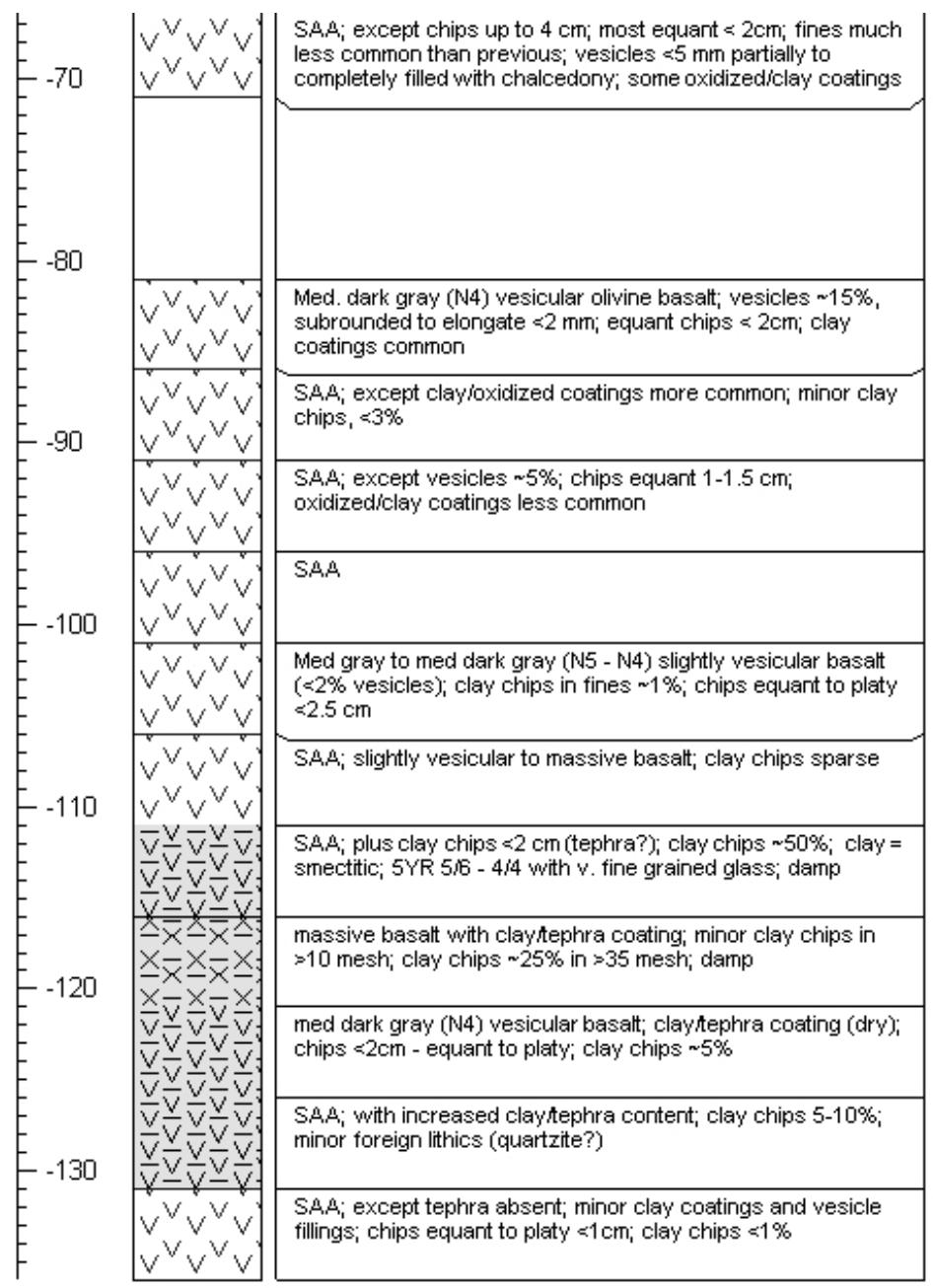

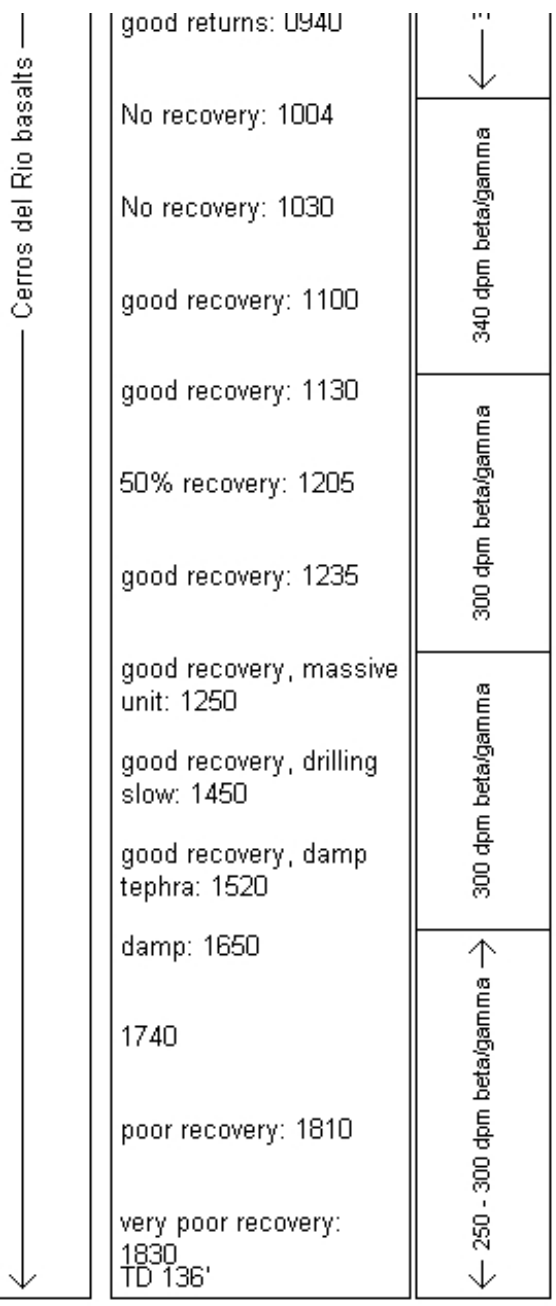





\section{Appendix B}

\section{Water FLUTe ${ }^{T M}$ System Installed in LAWS-01}

\section{Contents}

B-1. Location of sampling and transducer ports in LAWS-01 liner

B-2. Schematic diagram of sampling assembly employed in Water FLUTe ${ }^{\mathrm{TM}}$ systems

\section{Notes}

The Water FLUTe ${ }^{\mathrm{TM}}$ liner is placed inside the 6-in. PVC production casing, which contains four screens:

$\begin{array}{cc}\text { Screen } & \text { Depth (ft bgs) } \\ 1 & 83-84 \\ 2 & 158-168 \\ 3 & 188-198 \\ 4 & 263-273\end{array}$

See Table 3 for relationship between screens and ports in liner.

See Figure 9 for relationship between screens and geology. 



\section{B-1. Location of sampling and transducer ports in LAWS-01 liner}

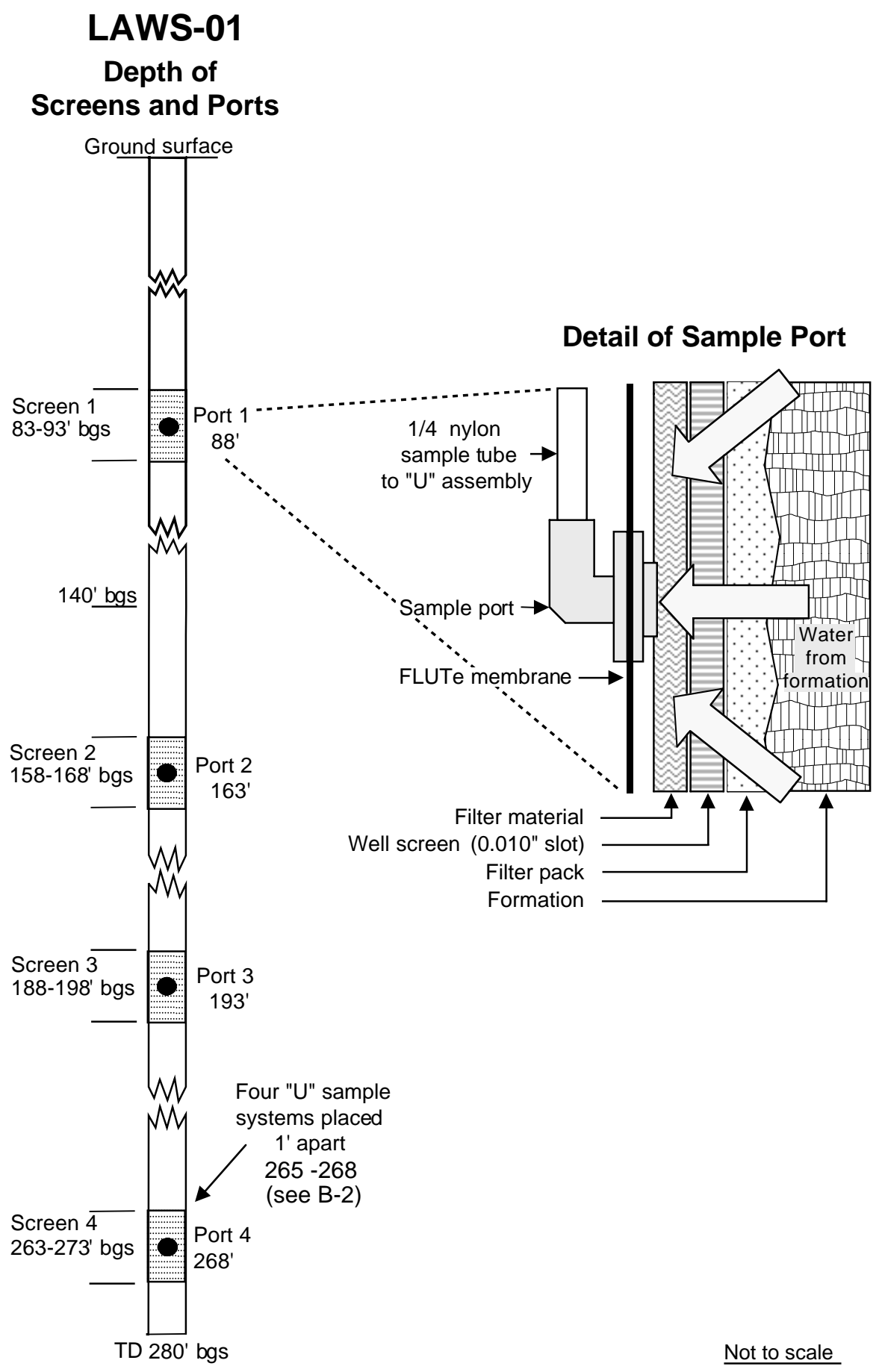




\section{B-2. Schematic diagram of sampling assembly employed in Water FLUTe ${ }^{\mathrm{TM}}$ systems}

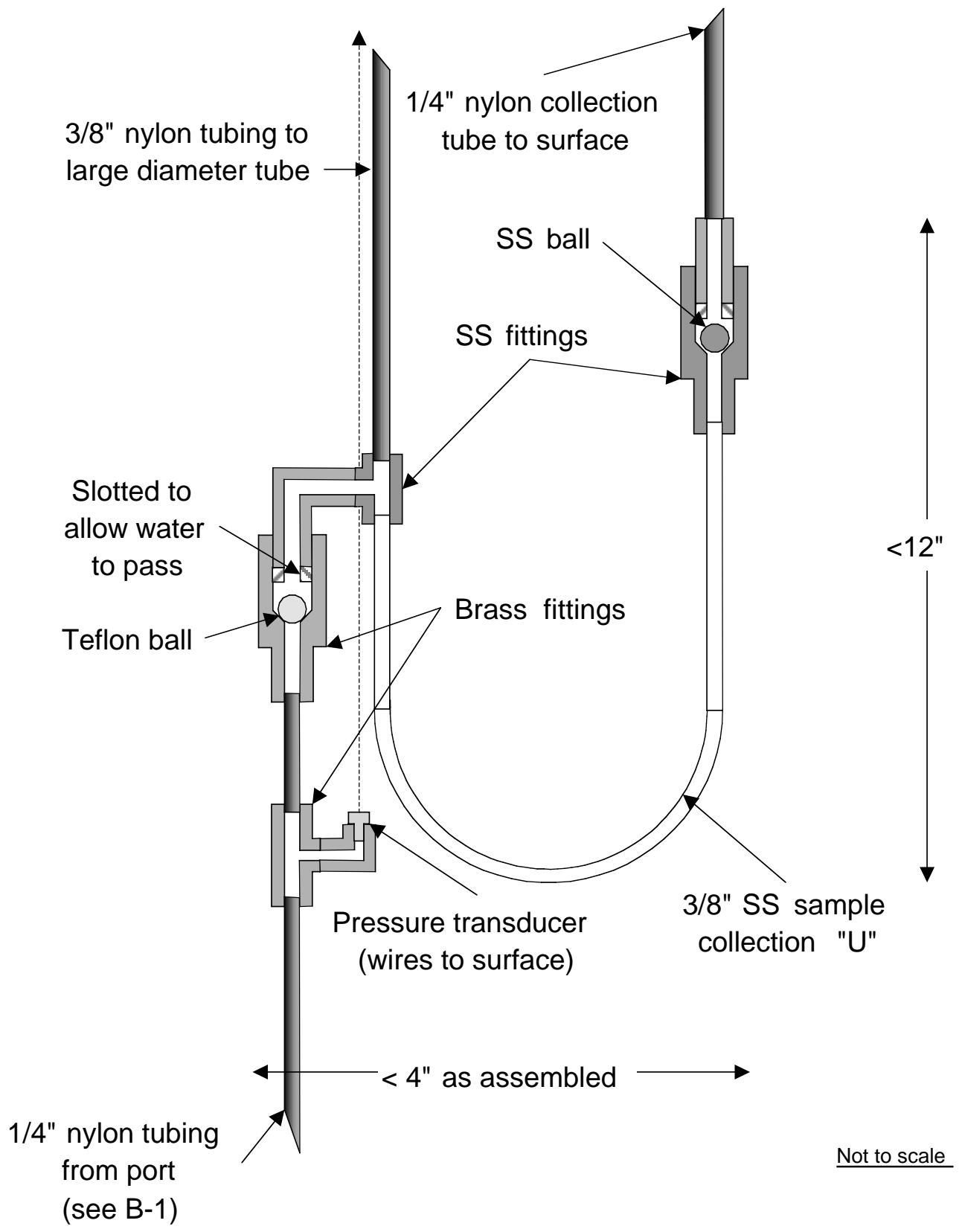




\section{Appendix C}

\section{Construction of the Angled Boreholes}

\section{Contents}

C-1. As-built diagram of the scalloped shield used in LAWS-02

C-2. As-built diagram of the perforated pipe shield used in LAWS-03

\section{Notes}

Shields in both boreholes were made from 6-in.-I.D. PVC.

Shield in LAWS-02 consists of alternating scalloped and blank joints of PVC.

Shield in LAWS-03 has no blank intervals.

See Appendix D for wellhead-completion details. 



\section{C-1. As-built diagram of the scalloped shield used in LAWS-02}

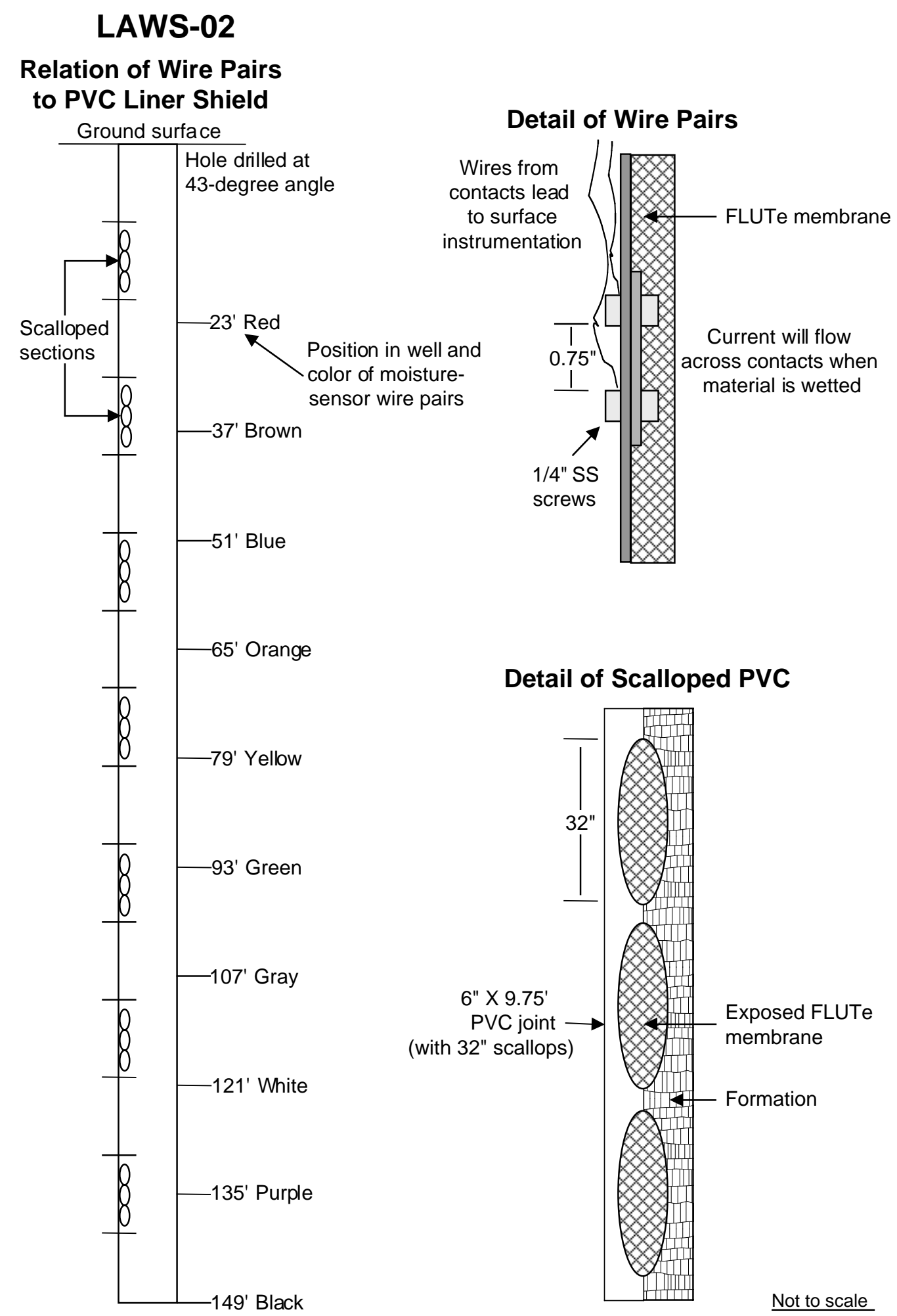




\section{C-2. As-built diagram of the perforated pipe shield used in LAWS-03}

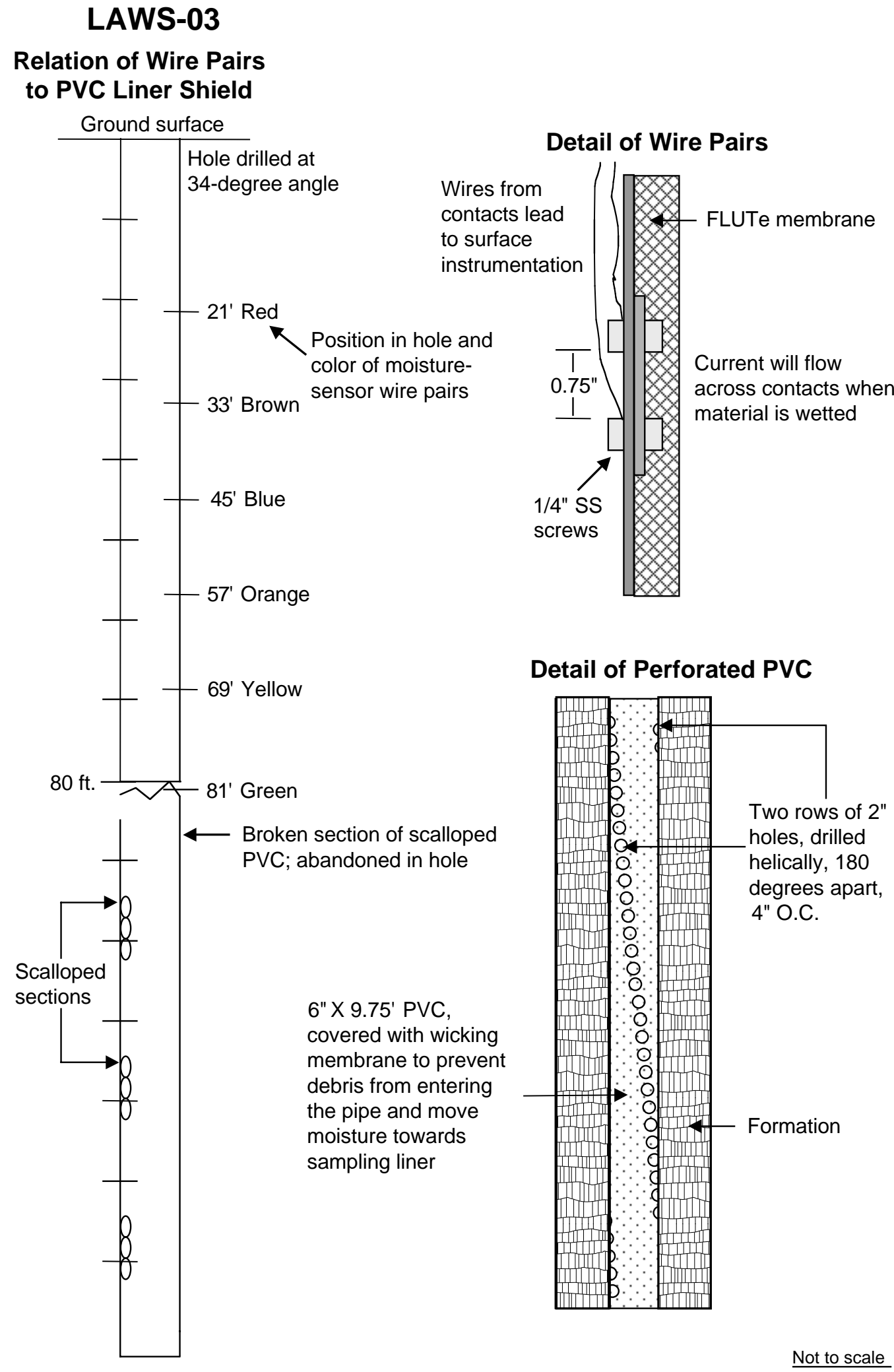




\section{Appendix D}

\section{Wellhead Completion for the Well and Boreholes}

\section{Contents}

D-1. Schematic diagram of the wellhead at LAWS-01

D-2. Schematic diagram of the wellhead at LAWS-02

D-3. Schematic diagram of the wellhead at LAWS-03

Notes

See Figure 20 for typical wellhead protection.

See Figure 21 for wellhead completion at all three holes. 



\section{D-1. Schematic diagram of the wellhead at LAWS-01}

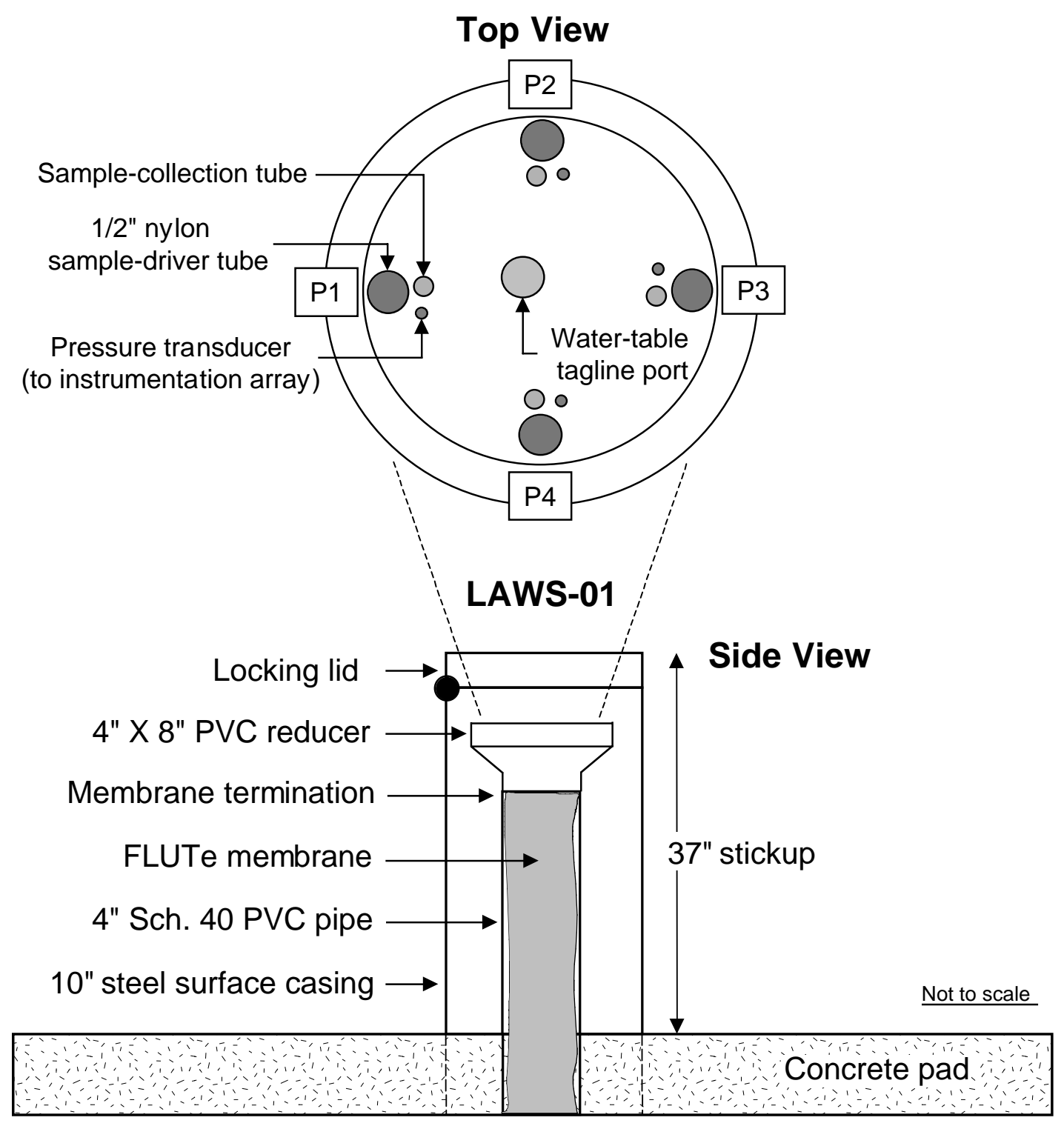




\section{D-2. Schematic diagram of the wellhead at LAWS-02}

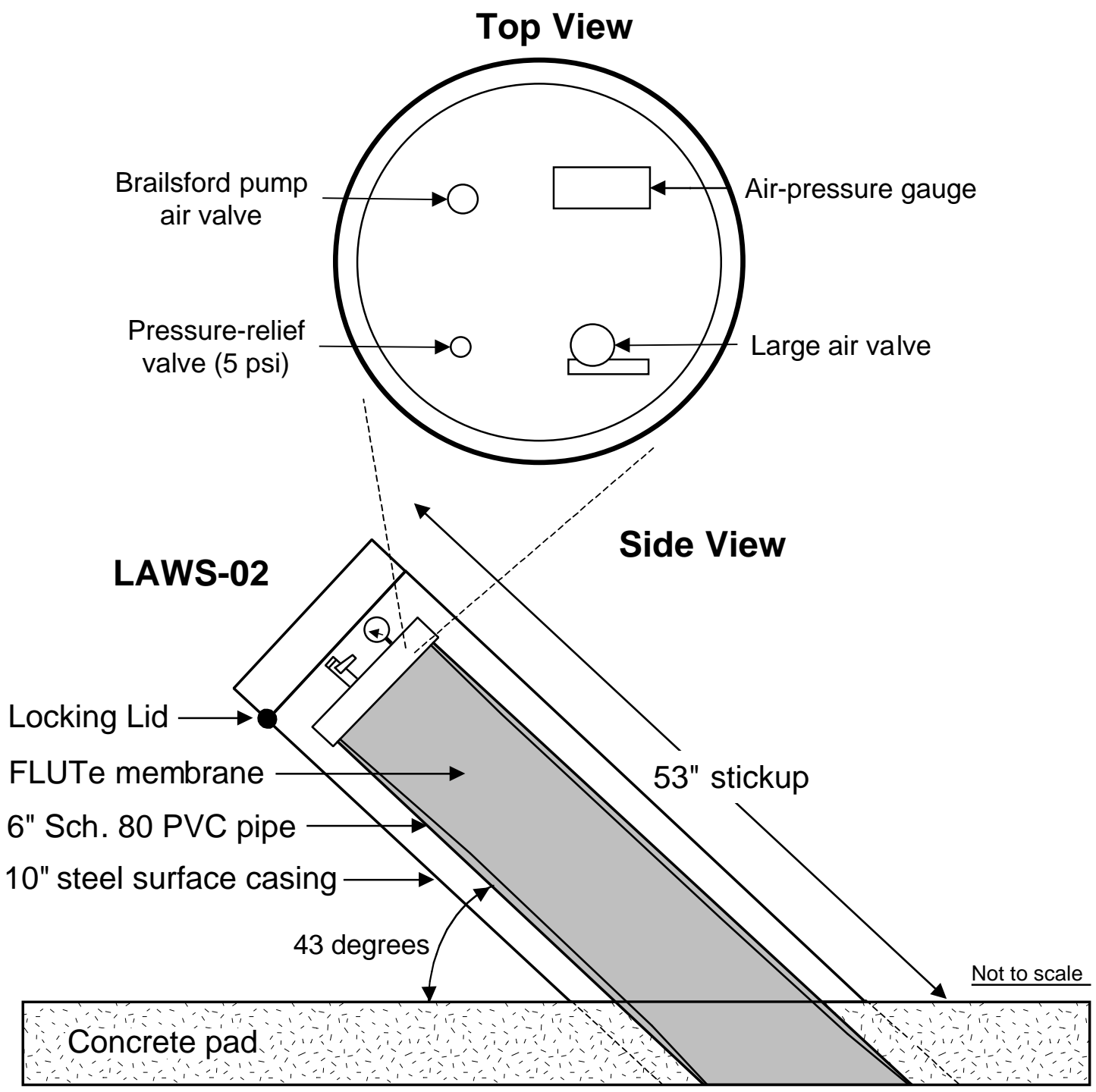




\section{D-3. Schematic diagram of the wellhead at LAWS-03}

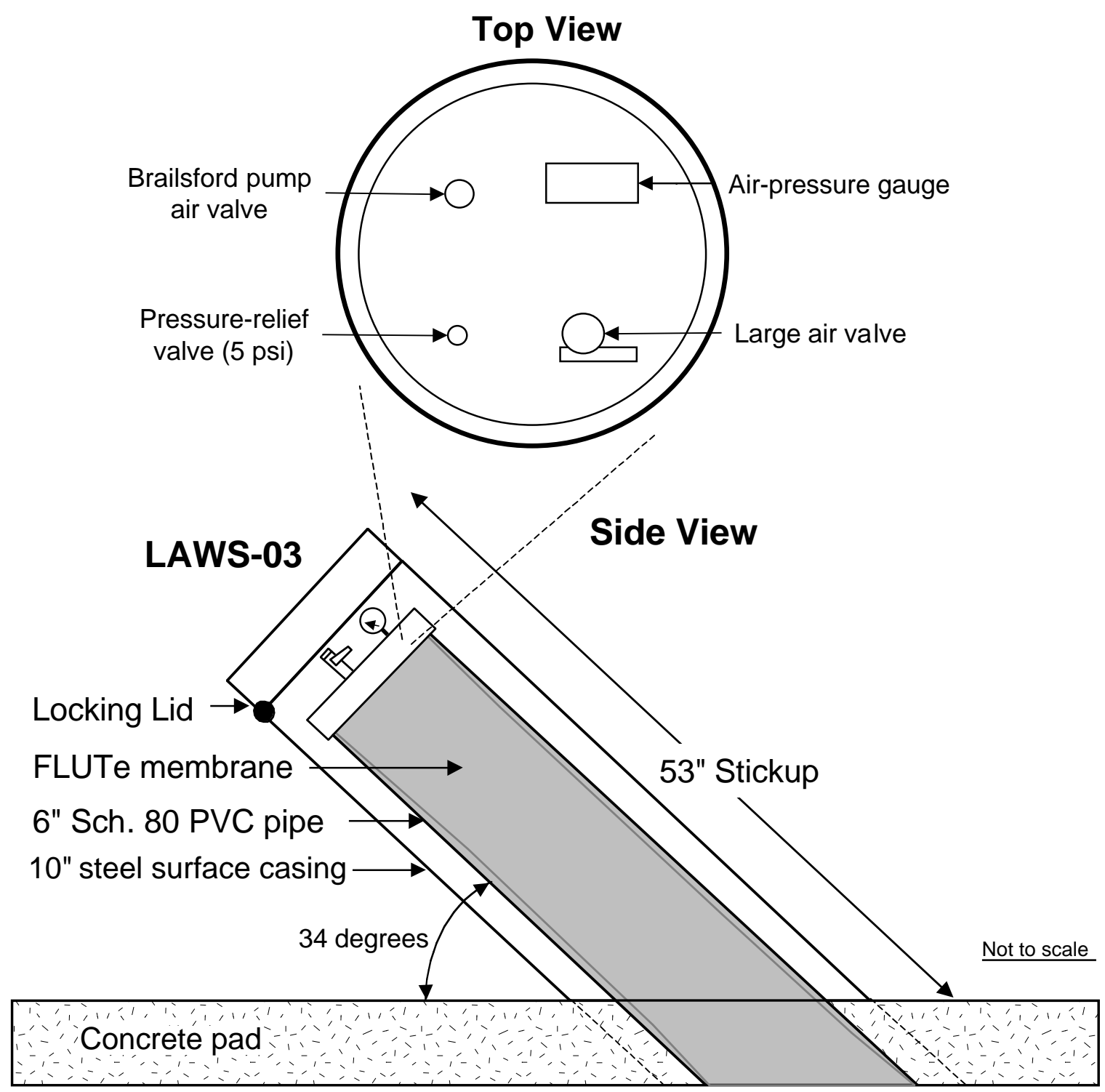



This report has been reproduced directly from the best available copy. It is available electronically on the Web (http://www.doe.gov/bridge).

Copies are available for sale to U.S. Department of Energy employees and contractors from

Office of Scientific and Technical Information

P.O. Box 62

Oak Ridge, TN 37831

(865) 576-8401

Copies are available for sale to the public from

National Technical Information Service

U.S. Department of Commerce

5285 Port Royal Road

Springfield, VA 22616

(800) 553-6847 
